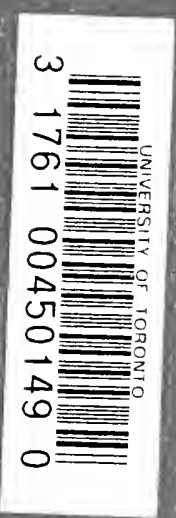

9.54

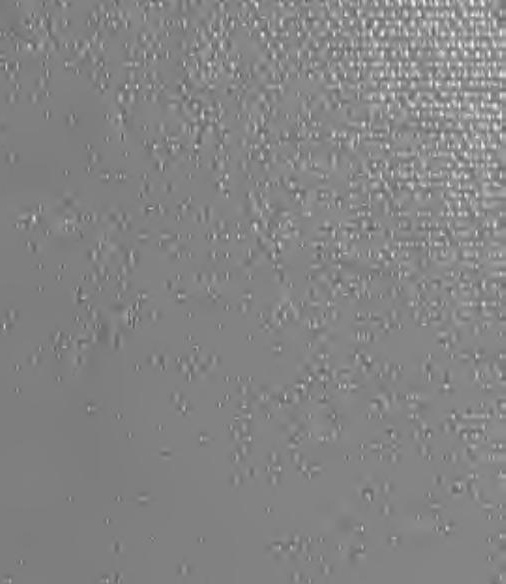


Digitized by the Internet Archive in 2008 with funding from Microsoft Corporation 




\section{TH F}

\section{BOXER RISING:}

A History of the Boxer Trouble IN China.

Reprinted from the "Shanghai Mercury."

2与ำ

SECOND SDONTON.

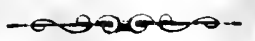

$\frac{509502}{19.7 .50}$

Printed at the Shanghai Mercery, Ltd.

AUGUST, 1901. 



\section{CONTENTS.}

Pages.

Preface to First Edition

do.

Second Edition

$\cdots$

$\cdots$

History of tile Boxer Mlovement

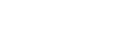

Tile Beginning of tile Outbreak $\quad \ldots \quad$...

Tine Scene of Strife $\quad \ldots \quad$... $\quad$.. $\quad$...

Eye-Witness's Narrative $\quad \ldots \quad$...

Story of the TakU Forts Boybardment

The Ladies and Childrex at Taku ..

Adventures of Tongshan Refugees ...

The Disturbance in East Sulanturg

Tiie Siege of Tiextsin ..

Escape of the Shantung Missionaries

News froy Chefoo

Afrains in Wexcilow $\quad . . \quad$...

Native Account of time Situation

The Situation at Cinfoo

The Murders at Kuchau

News frodi tile Yangtze

The Situation in Szeciluan

Wenchow Affairs

The Fich

A Native's Expeiriences in Peking ...

Kiating

Tile Trouble at Amor

Shansi Missionaries ...

The Position at Tievtsiv

Tientsin and Peking $\quad \ldots \quad \ldots$

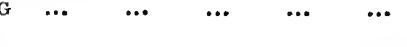

Tientsin Notes $\quad \ldots \quad$...

The Siege of Peking $\quad \ldots \quad$...

The Taking and Occupation of Peking

Plan of Preing

Tile C.atiledral Siege in Peking

Tientsin to Peking by Bont ...

Peking Day by Day

Tine Pao.ting-Fu Expedition ...

Tirriling Experiences of C.I.M. Missionaries in Chithi 

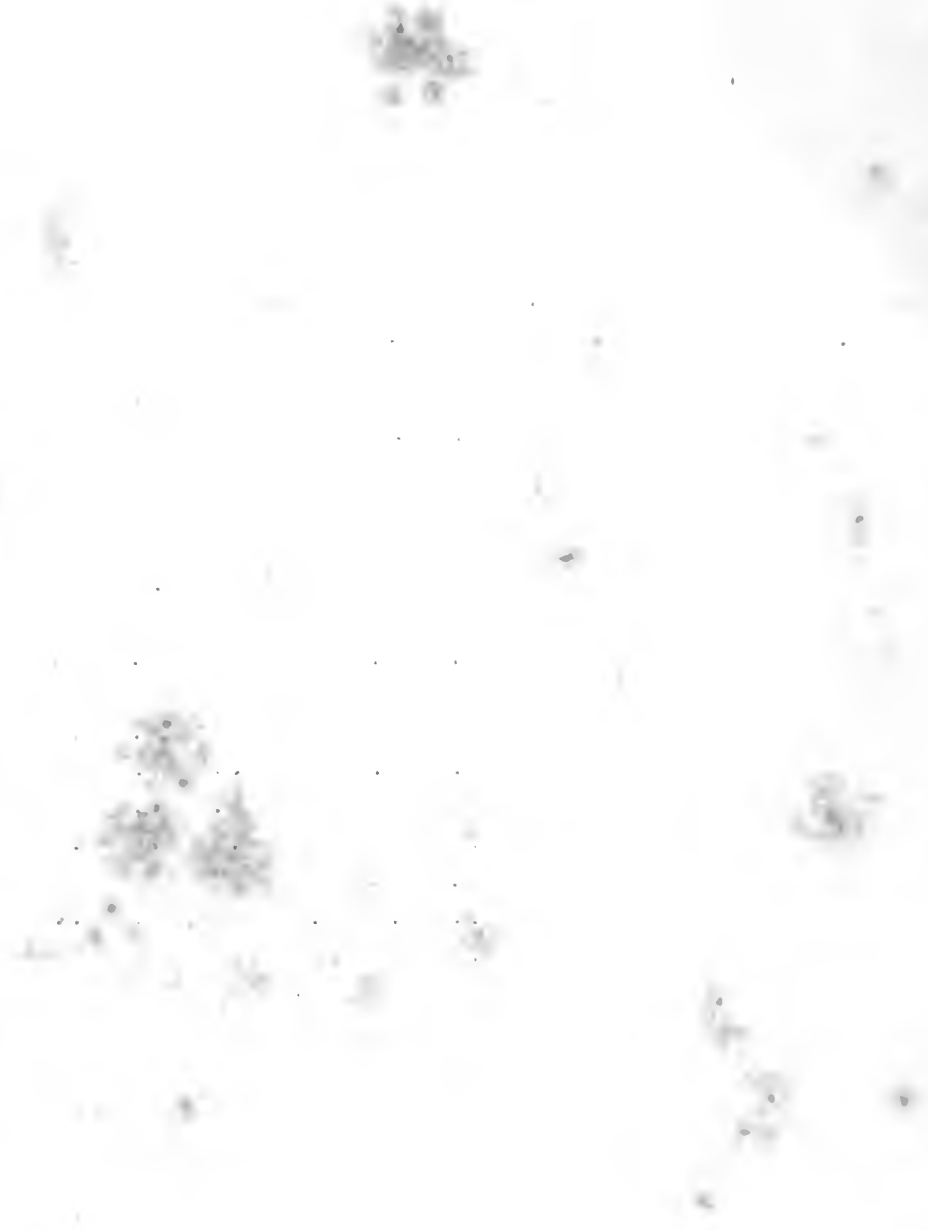

4 


\section{PREFACE TO FIRST EDITION.}

If $\mathrm{N}$ view of the dramatic events which have transpired in China during the past few months we have thought it would meet the wishes of the readers of the "Mercury" to reprint the special articles which appeared in our columns describing the various acts of the drama which has passed before our eyes, and thus permit of their being preserved in a more permanent and convenient form than is possible in the columns of a newspaper. There has been no attempt to specially prepare the articles for publication in their present from and they are printed as they originally appeared. We have to express our thanks to all those, our correspondents and others, whose contributions are now republished.

While it is perhaps impossible to fix any date as being the beginning of the Boxer trouble, the announcement of the burning of a station on the Lu Han line on I $7_{\text {th }}$ May, which appeared in the "Mercury" of 29 th May, may be said to have been the first indication to the general public that a rising which had for its object the expulsion of foreigners from China had really broken out. Previous to this, on 2 ist May, the Foreign Ministers at Peking had sent a joint note to the Chinese Coverment calling attention to the Boxer troubles, but 
it cannot be said that even the signatories themselves fully realised the extent or design of the plot. From this time events followed each other with startling rapidity. On 26th May, the Boxers burned the stations on the Railway beween Peking and Paotingfu, and Fengtai station and works were burnt, and railway communication between Peking and Tientsin was of course interrupted, while the Belgian engineers and other refugees from Paotingfu had to cut their way to Tientsin, where, after terrible sufferings, most of them ultimately managed to arrive on the 2nd June. Communication with Peking being temporarily restored on the 29th May, the Ministers sent for guards of their nationals for their respective Legations, and on the 30 th these commenced to arrive at Tientsin. On the 3 Ist May British, American, French, Russian, Italian and Japanese guards for the Legations left Tientsin by rail, and reached Peking safely, but their presence was only the signal for renewed outbreak with increased violence, as a great incendiary fire occurred in the native city of Tientsin on the Ist June, while two missionaries, Messrs. Norman and Robinson, were murdered under circumstances of shocking barbarity. On 5th June railway communication between Peking and Tientsin was finally cut. A large composite force was landed at Taku on the 7 th June and on the Ioth Admiral Seymour left Tientsin with 2,000 Allied troops to attempt the relief of the Legations, while at the same time all communication by telegraph between the Ministers and the outside world suddenly ceased. On the I I th June the Secretary of the Japanese Legation was murdered in the strects of Peling, and on the 2oth, 
the Foreign Ministers having been ordered by the Tsungli Yamen to quit Peling and been promised an escort, Baron von Ketteler, the German Minister, who was proceeding to interview the members of the Tsungli Yamen on the subject, was brutally murdered in the streets by an officer of the regular Chinese troops. Meanwhile the extent of the rising and the complicity of the Chinese authorities had been recognised by the Foreign Governments and preparations were commenced by all the Powers who had embassies in Peking for the despatch of troops to China. On I th June Admiral Seymour was completely cut off, the railway having been destroyed behind him, while communication between his force and Tientsin was impossible. At the same time the position at Tientsin had become most critical, the native city being completely in the hands of the Boxers while all the Christian Chapels in the city were burned and many native Christians murdered. On the I6th June the Allied naval commanders, considering the attitude of the Chinese troops as threatening, demanded the surrender of the Taku forts, but in reply to the ultimatium the forts opened fire on the foreign gunboats in the Peiho river early on the morning of the I7th. However, after a fierce fight between the gunboats and the forts, a magazine in one of these latter was blown up by a shell, and the other forts were taken by storm.

On the same date the Chinese commenced the bombardment of Tientsin, and the situation there became most critical. Two attempts to reach Tientsin from Taku failed, but a third attempt on 23 rd June was 
successful, and the position then became less desperate, although the Chinese Boxers and regular soldiers remained in force in the neighbourhood, and the bombardment from the native city continued. Admiral Seymour, who had managed to force his way till within 25 miles of Peking, found further advance impossible, and was compelled to retreat, a task of the utmost difficulty and danger, but on 26th June, being joined by a small force from Tientsin, he succeeded in returning there in safety. Foreign troops had in the meanwhile been arriving at Taku, and it was found possible to reinforce Tientsin, the strain on the defenders of which was very severe. Messages from Sir Robert Hart, Sir Claude Macdonald and Mr. Conger had been received through native runners about the end of June and the beginning of July, and these all reported the situation of the Legations as desperate. On the 9th July the Japanese captured the Tientsin Arsenal, and on the I I th the Allies made a combined attack on the native city, which was captured, but not without heavy loss. For some considerable time no communication had been received from Peling, and this ominous silence gave rise to the gravest fears for the safety of the besieged foreigners, a wild rumour of their massacre even at one time being generally credited.

In the Far North, at Blagovestchensk, on the Amur River, the Chinese had made a fierce attack on the Russians, and came near to being successful in capturing that city, and this diversion had the effect of temporarily stopping the despatch of Russian troops from Siberia to Taku, while attacks on the railway in 
Manchuria occasioned the Russians considerable trouble, with the result that ultimately the Russians bombarded and seized Newchwang.

Appeal for mediation in the name of the Emperor of China were made first to the Emperor of Japan, and afterwards to the other Powers, and on 22nd July Li Hungchang landed in Shanghai, and attempted to open negatiations with the Allied Powers through the Foreign Consuls, but at first with but little success.

On $5^{\text {th }}$ August the advance on Peking commenced, the Chinese being attacked and routed by the Allies at Peitsang. Next day Yangtsun was captured and occupied, and on the 9th Hosiwu was reached, and on the I Ith Matou. On the I4th the Allies were outside the walls of Peking, which was entered and the foreigners rescued on the I 5 th August.

At this time the centre of interest shifted to the South. For the protection of Shanghai the British Government sent a body of Indian troops, and these arrived at Woosung on the I4th August, but protests having been made against their landing they did not immediately proceed to Shanghai. However, at the request of the Foreign Consuls the troops--three regiments, Baluchis, Rajputs and Gurkhas-were landed on the i8th. These were followed by about 600 French on 27 th August, 500 Germans on 6th September and about 200 Japanese on roth September, while the British force was strengthened by a regiment of Sikhs and a squadron of Bombay cavalry and the Jodhpore Lancers.

A Japanese temple having been burned at Amoy on 24th August, about 200 Japanese were landed there in 
spite of the protests of the other Foreign Consuls, and a small party of British bluejackets was landed to protect the British concession, but as no outbreak took place and the Chinese authorities were friendly and desirous of maintaining order all the Foreign troops were withdrawn on 7 th September.

Previous to the entry of the Allied force into Peking the Emperor, Empress-Dowager, and Chinese Court had fled, and on 3oth August, it was understood, they arrived at Sian, Shensi. To demonstrate to the Chinese the complete success of the Allies a triumphal march of detachments of each nation was arranged through the Sacred City of Peling and was carried out on 28 th August.

An edict having been issued purporting to be from the Emperor appointing Prince Ching and Li Hungchang peace negotiators, on I4th September Li left Shanghai on board the Anping and arrived at Taku a few days later, whence, under the protection of a Russian guard, he proceeded to Tientsin.

Count von Waldersee who, with the consent of all the Powers, had been appointed commander-in-chief of the Allied forces, arrived at Shanghai by the German cruiser Hertha on 2ist September, and the following morning he inspected the Shanghai garrison, including the Volunteers, and proceeded North to Taku the same evening. It does not appear likely, however, that any military operations other than punitive expeditions will now be undertaken, and it is probable that the remaining acts of the drama will have diplomatists as the principal actors. In this connection the appointment of Sir Ernest 
Satow as British Minister in. place of Sir Claude Macdonald and the transference of Sir Claude to Japan in Sir Ernest's place appear to be significant. Sir Ernest arrived at Shanghai from Japan on 28th September. Baron Mumm von Schwarzenstein has also been appointed Ambassador for Germany in place of the murdered Minister Baron von Ketteler.

Shanghai Mercury Office,

October, 1900.

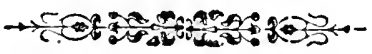




\section{PREFACE TO SECOND EDITION.}

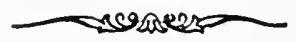

Gif HEN it was decided last autumn to publish in book form the special articles which had appeared in the columns of the "Shanghai Mercury" depicting the principal events in the extraordinary movement which culminated in the siege of the Foreign Legations in Peling last summer, it was not anticipated that the reception by the public would be so gratifying, the whole edition being quickly sold out. After the book was out of print, however, many orders were received, and much regret was expressed by those unable to obtain copies. To meet this demand, therefore, it was resolved to issue a second edition of the "Boxer Rising" and this is now offered, to the public. As most of the matter in the first edition was taken practically as it stood from the columns of the Mercury, the style has been slightly altered to make it more suitable for book form, although scarcely any changes have been made in the text. Two or three new articles have been added to this edition, which has been reset in new type, and the publishers hope the book may prove of some slight value to those who desire to preserve the story of events which will probably have effects on the history of China that cannot even yet be foreseen

When the introduction to the first edition was 
written in October last the opinion was hazarded that the further stages of the drama would have diplomatists instead of soldiers for the principal actors, and this prognostication has proved correct, as, although the military occupation has continued up to the present, any military operations undertaken have been merely of a local and punitive nature. In spite of the large number of Foreign troops in and around Peking, a state of anarchy has prevailed in Chihli, which the Allies, probably owing to inability to easily distinguish between peaceful inhabitants and lawless banditti, have been utterly unable to cope with, and, although the state of the country is still as unsettled as ever, the Powers are now hurriedly withdrawing their forces, perhaps fearful that, with so many armed men lying in idleness, international jealousies, slight indications of which have not been awanting, might lead to an explosion the consequences of which could not be confined to China.

When the Foreign diplomatists commenced negotiations with the Chinese Peace Commissioners great hopes were entertained that the result would be a general opening of China to the civilisation of the West, and it was thought an era of Reform was imminent. There hopes, however, have proved illusory. Very little attempt seems to have been made to induce the Chinese to reform their administration, and the corrupt mandrinate are still to be allowed to govern as of yore. The efforts of the plenipotentiaries at the beginning of the negotiations were confined to trying to induce the Court to return to Peking, but the wily EmpressDowager refused to listen to the blandishments of the 
Foreign ministers, and the Court still remains at Hsian, nor is it definitely known whether it will even yet return, although the bulk of the Foreign troops have been withdrawn. Latterly the Powers contented themselves with exacting a big indemnity, some of the claims being most extravagant. The Chinese Commissioners willingly agreed to all the demands, although it is probable that when the question of payment comes up matters will not go quite so smoothly. In the meantime the money is to be raised by loan, each power guaranteeing its own share, a plan which seems worthy of China. Although present indications of any permanent good to either Foreigners or Chinese being the outcome of the present complications are not promising, it is to be hoped that the ultimate result will be the awakening of China, and the bringing of its out-of-date customs and methods in line with the requirements of modern civilisation.

Shanghai Mercury Office,

August, I90I. 


\section{THE BOXER RISING.}





\section{THE BOXER RISING.}

\section{History of the Boxer Movement.}

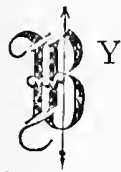

Y the courtesy of Dr. Hykes, of the American Bible Society, we are enabled to publish reports of the Tientsin agent of the society written shortly before the recent outbreak, which form a complete history of the Boxer movement from its inception tiil the investment of the Legations:-

In order to present the matter intelligently it will be necessary for me to write a brief summary of the uprising from its beginning. While confined principally to Shantung Province, it is affecting seriously all Christian work in the North, and is rapidly assuming vast proportions and speading like a forest fire from village to village. I have gathered all the information possible from various sources, both native and foreign, but as it is important that only facts should be presented, I will make only such statements as are amply proven. Most of the statements given below are those which have been communicated officially to Minister Conger by our American missionaries, and they do not include the reports of innumerable outrages of which we have not reliable information. 'The I-ho-ch'uan (righteous harmony fists ), commonly known as the "Boxers," is a so-called secret society which made its first appearance about one year ago. It rapidly attracted multitudes of men, both young and old, who formed into small bands of gymnasts. Each band was conducted by a "demonized" leader, who, by the selection of an epileptic or by the patient aid of hypnotism, caused a "medium" to display wild and unnatural symptoms or to utter wild and strange speech, this serving as a basis for the claim of this Society to spiritual power. Every follower was assured of immunity from death or physical injurytheir bodies being spiritually protected from sword cuts and bullets. By the first of last July the Boxers had added vast numbers to their ranks, and all were armed with broad-swords and in some cases with fire-arms. Gymnastic exercises and drills were going on in hundreds of villages, and the Boxers soon announced their intention of rising against the Roman Catholics, there having been a strong feeling of 
hostility toward them for ycars, a fecling which was intensificd in ISgS, when the Catholics purchased a temple in the village of $\mathrm{Li}$ Lien Yuan and replaced it by a church. At that time eighteen villages united and attacked the chapel. The Boxers finally became so powerful and so much in evidence that the Governor of Shantung sent a force to disperse them, which only incited them to more open and bitter opposition toward the Catholics, against whom they began to stir up violent opposition. They represented to ignorant multitudes that the sympathies of Government were with them, and adopted as a motto "Exalt the Dynasty and extirpate the Foreigners." One placard, which was widely circulated by them, reads as follows:-

\section{"The Universal Boxer Society :}

You are personally invited to meet on the seventh day of the ninth moon.

Elevate the Manchus.

Kill the Foreigners.

Unless this summons is oljeyed you will lose your heads."

From the time this placard was issued up to the present, Shantung has been a scene of riot. Aimed originally at the Roman Catholics, the movement gradually grew into opposition to everything foreign, and the natives in both Catholic and Protestant churches were the sufferers. Hundreds of native families were rendered homeless, many were killed, and the Boxers, unchecked, looted and burned and robbed and killed until they were beyond control. A recital of the various attacks cannot be given here-it would fill a a volume. In December in one district alone, the homes of two hundred families had been looted and burned, all available property confiscated and the sufferers forced to flee without food or sufficient clothing, in the midst of an unusually cold winter. Some were captured and held for ransom, others were taken to temples and forced to kneel before heathen idols, but most of them were taken in by missionaries and given such aid and protection as was possible. In the meantime the officials have been wholly unmindful of the teriors surrounding them. Indeed it is now known that the former Guvernor of Shantung had encouraged and aided the Boxers in their organization, and this (apparently) with the approval of the Central Civernment. What was at first anti-Catholic, then anti-Christian, now proves to go deeper-it is anti-Foreign. The Peking Government spoke of the Boxers as "patriots," and they were believed to be formed as a sort of militia to prevent the encroachments of the Germans in Shantung and to support the Government. Thus the pillaging and rioting went on unchecked, notwithstanding repeated warnings and petitions both from the native sufferers and the missionaries. Minister Conger acted promptly upon all information as received, but in spite of ready acquiescence and polite letters from the Tsung-li Yamen (Forcign lisureau) nothing was really done to put down the rebellion, now properly so-called, since it had passed beyond official cuntrul. Finilly Mr. Brooks was captured by the Boxers, mutilated 
and beheaded, and then the extreme gravity of the situation was revealed-the Government could no longer govern, nor afford protection, nor stay the rebellion. Of this event Minister Conger wrote, "This has finally aroused the authorities here to the extreme gravity of the situation, and a special Edict has been telegraphed General Yuan (Military Governor) to forthwith arrest and punish the offenders and also to punish all derelict officials, and he promises prompt and energetic compliance." Despite this Edict it was apparent that there were varied counteracting forces at work. There was evident pressure on the wrong side from Peking, and this met with ready response on the part of the Chinese. In a telegram to our missionaries in December, Mr. Conger says "Tsungli Yamen has peremptorily ordered Governor despatch soldiers; use every means suppress rioters, afford protection," and nine days later he had secured a promise that they would take "vigorous action" in Shen Chou. Not the smallest attention was given to these promises. When the missionaries asked for troops, in view of the terrorized condition of three counties, Mr. Conger telegraphed that "Yamen sent instructions send troops," but no troops were sent nor was there any reason to think that such orders were ever issued. H.E. Yu Hsien, the Shantung Governor, who had fostered and aided the Boxers, was removed under foreign pressure and replaced by General Yuan Shih $\mathrm{K}$ 'ai, but although supposed to be in disgrace for his failure to suppress the rioters, he was received with honour by the Court in Peking, and presented with a scroll written by the hand of the Empress-Dowager-a mark of high favour. Great things were promised by General Yung, but as yet it cannot be said that he has accomplished anything. Neither previous to his arrival in Shantung nor since has there been any arrest of the leaders, so far as is known. There is a popular impression, widely prevailing, that this rebellion is approved in Peking, and nothing has tended to dissipate this impression. True, some Boxers have been killed (the lack of spirtual protection being due to their lack of faith!) but the spirit of defiance has not diminished and on every hand may be heard open threats that when spring arrives vast armies of Boxers will march on to Tientsin to join General Tung Fu Hsiang, who is believed to be awaiting them, when "every foreign devil will be swept into the sea and China will be saved." Impossible or improbable as the thrcats of the Boxers may seem, they are not to be lightly regarded. The whole plan of the Society is impossible of execution, yet it has already cost great numbers of lives, devastated great areas, and the outrages do not diminish. The movement continues to spread from county to county, and has now passed the borders of Shantung into Chihli. The first outbreak in Chihli Province took place on the night of December 3 Ist, when a large number of Boxers attacked a Roman Catholic station, burned the chapel, and killed and mutilated two natives. The district magistrates have all been manifestly inefficient or thoroughly in sympathy with the Boxers. One, who has efficient and active, was removed from his post, a fact that requires no comment. The officials without exception are content to parley with the rioters, asking them 
as a favour to refrain from drilling, and if this is refused, dropping the matier entircly. In reports to their superiors these officials deny the presence of Boxers in their districts, a fact which renders it impossible to ask for troops, since there is no need for them! The methods adopted by the local officials are illustrated by the act of the Hsia Chin Magistrate, who on one occasion found a large force assembled to plunder on the border of his district. He requested them to cross the river into Chihli, and to facilitate this gave them an abundance of bread-cakes, as he had done to another army of Boxers in his own city a month before. The Boxers gladly crossed the river, but when the Magistrate had departed, to report that he had met and dispersed the bandits, they returned to resume their plundering in his own county. This is a fair sample of Chinese government and diplomacy. In a later instance this same magistrate replied to the Foreign Bureau, when complained of by Americans, that he appeared with an army and routed the Boxers, the fact being that he forbade the troops to fire a shot. The P'ing Yuen Magistrate, whose district is alive with rebellion, went last month to a large market toim (a Boxer centre) and had the headmen sign a paper declaring that there were no Boxers there, he promising that previous offences should be condoned. This document was only one of many similar ones sent into the Government, other magistrates have followed the worthy example of this one, thus relieving themselves of responsibility and excusing their inaction. It is through such men that reports must reach the Government-at whose hands we must look for justice. The situation is still serious-the reign of terror is far from ended. Iundreds have reported heavy losses, but owing to the terror inspired by the Boxers there are many who dare not complain for fear of new outrigres. An unusual depth of snow and the extreme cold have added to the sufferings of the homeless ones and there is more misery in store fur those who are faithful to the cause of Christ. The latest report ( $u_{i}$ ) to Jan. 3 Ist, I900) are similar to the earliest ones-almost no leaders have been arrested and the officials are still inactive. An Imperial Edict of last month warns officials not to confuse the patriots who are drilling for national defence with rioters, and to be cautious in awarding punishments. Meanwhile the situation is, as the missionaries have repeatedly stated, hopeless, unless there is united and determined pressure from the foreirn ministers. The missionaries are still airling and protecting as much as possible all native Christians who come to them, and the Romon Catholic Bishop at Chi Nan Fu reports that he has five thousand refugees in his care-a figure which gives some idea of the ruin which has been wrought. The officials will doubtless pay all claims for lost or damaged property (under pressure), and in fact the London Mission already reports that in one district the magistrate has paid claims to the amount of Tls. 2,400. liut the mere payment of claims does no good, and the fact that no punishments are awarded means much in a country like China. To a Chinese it means that the claims are settled under compulsion, but that the acts of the Boxers are approved by the Government. The 
bitter past, with its murder and pillaging, is all to go for naught if the Chinese have their way. Two years ago the Germans required the dismissal of Li Ping Heng, the Governor under whose rule two priests were murdered, and the Edict in the "Peling Gazette," dismissing him, contained the words "yung pu t'i yung" (not to be mentioned for employment again). This same man has just been put into a new and highly influential position, created for his sole use, where his power is aimost unlimited. Recently this Li Ping Heng, once in disgrace (?), but now high in office and favour, recommended to the Throne, as one loyal and patriotic and to be implicitly trusted, Yu Hsien, the late governor of Shantung, who, after eight months of rule, during which he gave a new lease of life to the Boxers, has left a track of ruin behind hirn. Such is Chinese duplicity-such is China's hopelessness. I am indebted for most of the facts presented above to Dr. H. P. Porter and Dr. A. H. Smith, who have been in the centre of the trouble from its beginning. They have recently drawn up the following charges agrainst the officials named, one copy (in Chinese) having been sent to the military governor and another to Minister Conger :-

Memorandum of charges against ofincials in connection with the I Ho Ch'uan rebellion. Presented by American Missionaries at Pang' Chuang, Shantung.

\section{I.-Against H.E. Yu Hsien, late Governor of Shantung.}

That knowing the existence of the I Ho Ch'uan in this province, on a large and threatening scale, a society wholly contrary to the Imperial laws, and in previous reigns severely punished, he took no steps to antagonize it. That after a fight had taken place in October, between the provincial troops and the Boxers, the said Governor was very angry that about a hundred of the latter had been killed, although told by the military officials that the encounter was unavoidable. That he then secured the degradation of the Prefect and of the Hsien of Ping Yuan, not for allowing this rebellion to go unchecked, but for trying at last to stop it. That he dismissed the military commander in charge at the time, and employed him no more for this reason. That he encouraged the Boxers by releasing the prisoners taken in that action, requiring no guarantee of good behaviour, to the immediate encouragement of the leaders, who had been ready to give up the cause after this fight. That he secretly promoted and fomented the rebellion by refusing to allow the troops to fight, repeatedly sending them into the field with these explicit orders. That his wellknown attitude was immediately influential in strengthening the rebellion, and was the direct cause of the murder of the late Mr. Brooks, as much as if the late Governor had despatched him with his own hand. That in a secret memorial to the throne he advocated the employment of the I Ho Ch'uan as an agency for driving foreigners out of the province, thus giving an official sanction to the movement. That for all the complicated storm of ruin in which so large a part of Shantung has been involved for so many months, Yu Hsien is directly 
responsible. We think that the Foreign Powers interested in the grood government of this province ought to insist that he be degraded, and the Edict should be published in the "Peking Gazette" with the phrase "never to be mentioned for employment again," and his conduct should be assigned as the reason for this step. Also that the said Powers should see to the perpetual enforcement of this punishment as only an adequate guarantee of peace in this province. (To demand the issuing of such a decree and then let it lapse into "innocuous desuetude" would be much worse than not to demand it.)

\section{II.-Against the Taotai, Intendant of the Circuit of Western} Shantung. (Against Chi Taotai.)

It is impossible for us to know what orders this official received from the late governor. We only know what the (American) Legation informed us to have been sent, and that no attention was paid to any of them. After explicit orders to have his troops fight, Chi Taotai refused to allow them do so, and he did nothing effective against the Boxers, although he was in their immediate presence for months together. Details of his inefficiency can be vetter presented by Americans at the Capital than by us.

\section{III.-Against Cheng Su, Magistrate of the County of Ping Yuen.}

This official being repeatedly appealed to to investigate the looting of the Christian families in a village in Ping Yuen known as Li Luchuang, did nothing of the sort. Being explicitly ordered through the Governor, by command of the Governor-General of Chihli, etc., to arrest a certain leader known as Chang $\mathrm{Yy}$ Cho, he not only took no steps to do so, but let it be known that he did not intend to do so, to the great abetting of the insurrection. Being repeatedly memorialized on the subject of the various nests of rebellion in his jurisdiction, he took no steps to discourage their drills and raids on peaceful Christians. Being petitioned in several individual cases of extortion of money from the families of Christians, and in the matter of threatening orders in the name of the I Ho Chuan to said Christians to pay money else have their houses looted and burned, he took no steps to prevent these acts in any single case, one family within three li (one mile) of the city being fined more than eighty strings of cash, although promising in letters to the missionaries in charge that he would "protect" Christians. When at last proclamations arrived from the Capital, they were posted in only a few places, and despite the stringent threats of these proclamations against the active Boxers, practically none have been arrested down to the present time. He has allowed the headmen of the several villages containing "Camps" of Boxers to certify that there are no such persons within their villages, and there the matter ends. To numerous letters of remonstrance from mission headquarters, he has either not replied at all, or only in insulting phrases, with an evident intention to ignore every claim from this source. Upon occasion of our complaint against a Boxer leader, who seemed to threaten our headquarters, this Magistrate sent for the 
leader and showed him the letter from here by way of a friendly hint. This official is to be superseded, but we ask that he be employed no more in Shantung.

IV.-Against the Sub-Prefect of Kao Tang, Li Enhsing.

The Christians within the jurisdiction of this official have been pillaged repeatedly, and in each case he has been appealed to either by petition from them or by letter from us, and in no single case known to us has he made any investigation or afforded any protection, meanwhile writing us fraternal letters full of polite deceit. These raids and fines have been inflicted in the villages of Kuan T'ung, Mai Kuan Tun, Ma Chuang, Wu Li P'u, Yuen Chuang, and later in the very west suburb of the city itself our chapel was looted without any attention being paid to this circumstance. Two Boxers were captured while oppressing a Christian family five li from the city, kept in prison for a month and then released, although it was known for certain that they were principals. One of our preachers was fined more than eighty strings of cash, the Magistrate taking no action. Another was beaten severely, the men being arrested and then released as mentioned. To the present time the proclamations have not been posted in villages at a distance from the city, and the terror inspired by the Boxers still holds. One important leader has been arrested in this district, sent to Hsia Chin for trial, and later to Chi Nan Fu, but the most of the rioters have been undisturbed, the Magistrate, surrounded with troops, pleading his inability to act.

\section{V.-Against Tu Nai Hsun, District Magistrate of Hsia Chin.}

This official was repeatedly petitioned by us on the occasion of threatening Camps of the I Ho Ch'uan being formed near his city and elsewhere. In one fof his letters he exhorted us not to listen to the tales of silly women and small children, the Camp meanwhile being formed and continuing to the present hour to be a source of peril to all neighbouring Christians. When a large body of Boxers visited his city he consoled them with seventy or eighty strings of cash and two hundred catties of bread-cakes upon condition that they should go elsewhere. Upon another occasion he visited a market town on the edge of his district, and bribed a hand of marauders to cross the river into Chihli by presents of bread-cakes, etc., reporting that he had "dispersed" them. Being warned by us repeatedly of the danger to our out-station of Ho Chia T'un, he disregarded the warning, although sending men there who did nothing. When a large armed force actually came he delayed going until the families had been looted and the chapel and residence destroyed, and he prevented the troops from fighting the remaining Boxers. Of his later acts we are imperfectly informed.

$$
\begin{array}{ll}
\text { (Signed) A. H. Suith. } \\
\text { H. D. Porter. }
\end{array}
$$

The above list of charges gives so clear an insight into the state affairs, that I have quoted it in full. 
Meanwhile Chihli is affected-the movement is spreading, and Christian work in the whole of North China is in danger. Within thiry miles of Tientsin the Bosers are drilling daily, and they have promised to attack us on the 15 th of this month, February. I have just returned frum Tungelsou, Peking and vicinity, and found that portion of the province quict, thourh it in infested by robbers.

'There is nothing new to report. General Yuen still does little or nothing in the way of capturing and punishing the Boxers, and it is to be fearel that all work will have to be suspended in Shantung. There is every prospect of long and bitter rebellion in that province, and the fecing arginst forcigners and the foren religion is on the increase, while the ranks of the ?3uxers are swelling at a tremendous rate. 'Thus far only' a small portion of Chinli has been affected, but it is difficult to say where the movement will end. Trouble has been anticipated in Peking, but on passing throumh there last week (Feb. Ioth) I found the crowds ordorly and weil disposed, although it is known that for some reason the Boxers have coliected there in large numbers, as they have likewise in the vicinity of 'lientsin. It seems hopeless when the uprising has passed the control of the civil authorities and the military refuses to act, but the most we can now hope for is that the trouble may be confined chiefly, as now, to Shantung.

The "Boxers" continue to arli to their numbers, and they are spreading quietly into Chilli, moving north towards Peking. There is perhaps less demonstration on their part, but from the quict but unceasing recruiting they are doing, and the spreading of the movement, it is evident that some great outbreak is planned. Well informed Chinese teil me that "I Ho Ch"uan" is but a new name for the old "White Lily Sect," which has never really died out and is at the bottom of this new organization. At all events the whole thing is now on a gigantic basis, and the fact that the working men of the best class are swelling its numbers makes it a matter more serious than is commonly supposed. Having stirred up so much trouble, and on account of the New Year holidays, they have rested from their pillaging (though religious work in Shantung is out of the question), but we may soon expect some great outbreak unless the Foreign Ministers take visorous action and back up such action by substantial threats. Large numbers of the Boxers are now in this vicinity as well as that of Peking, and it requires but a spark to ignite Chihli as Shantung was set into a blaze. I am leaving for Peking and vicinity next week, and will let you know the condition of the country as soon as I can get the reports of my men and others.

1 am cnclusing copies of the Imperial Edict and Viccroy's proclamation recently issued under pressure from the Iroreign Ninisters. Even after these documents were published there was no diminution in the enlisting, drilling or impudence of the Boxers. Large gatherings were held outside the Suth Gate o the city, where inflammatory speeches were made dy Buser leaders, not one of whom has been arrested. To enforce the Eelict, several half-grown boys were arrested, and are now exhibited in chains on the streets, while prominent 
and well-known leaders are permitted to go free. The large gatherings, however, have ceased, though the Boxers still declare their intention of carrying on the "good" work. Every village and hamlet in this vicinity has its branch organization, and the drilling has been carried on next to our foreign Settlement. An important feature of the ceremony seems to be knocking the head three times on the earth towards the south-east, after which they rise and begin pulling their ears, stretching their mouths and going through all sorts of fantastic gestures, until they fall to the ground in a stupor. They act very much like the famed dancing Dervishes, and in the midst of their "fits" utter strange language which is supposed to be spiritually inspired. They believe that an army of invisible soldiers supports them and that they are safe from rifle shot and sword, and this faith, which is doubtless real faith, leads them to fearlessly commit acts of lawlessness. Shantung is quieter, the trouble seemingly advancing to North Chihli. As the members are largely from the farming class, it is hoped that the arrival of spring and seed time will take them to their fields and thus the matter end, but their present concentration indicates a desire on their part for one grand slaughter before they separate, and this may and may not come to pass.

Copy of one of many of the "Boxer" placards, posted everywhere in the North of China, including cities, towns and villages:

\section{"Thus Sayeth Li, The God of Wealth and Happiness.}

"On accouut of the Protestant and Catholic religions the Buddhist gods are oppressed, and our sages thrust into the background. The Law of Buddha is no longer respected, and the Five Relationships are disregarded. The anger of Heaven and Earth has been aroused and the timely rain has consequently been withheld from us. But Heaven is now sending down eight millions of spiritual soldiers to extirpate these foreign religions, and when this has been done there will be a timely rain. In a short time there will be an encounter of weapons, and the soldiers and people will suffer calamity. People ought to hasten and rejoin the Buddhist faith as soon as possible. The I-ho-ch'uan can protect the Government and give peace and protection to the people, and the parents of families having seen this notice must make it known to others and thus avoid calamity to their families. Those who fail to publish it will suffer. If the foreign religions are not destroyed there will be no rain." of snow.

(Note.) This was scarcely issued when there was a plentiful fall

The Foreign Ministers in Peking having unitedly demanded an Edict to put down the Boxers, the following was issued by the Viceroy, after the Imperial Edict of similar tenor:-

\section{The Imperial Edict.}

"The Tsungli Yamen has memorialized Us to strictly prohibit the" 
Boxer Society. From telegrams sent by the Governor of Shantung last year we learnt that the Boxer Societies in every district were opposing religions, and exciting risings everywhere, even so far as southern Chihli. We have already repeatedly authorized the Governors of Chihli and Shantung to send troops to suppress them. Such kinds of secret societies which collect members from the people and cause trouble excite the ignorant people if they are not strictly prohibited, and the trouble is likely to be widely and vigorously spread. If any serious occurrence arises from such things we have no recourse but to send troops for their suppression, and this entails great loss of life. Our Government is not so hard hearted as to desire the death of the people, but would rather teach them better things. We therefore authorize the Governors of Chihli and Shantung to issue a plain proclamation and give a clear notification of prohibition to the people, in order to let them all know that the organization of such societies is illegal. They should cease their evil habits and become law-abiding, loyal subjects. If they persist in their foolish ways without reform they ought to be severely punished and no leniency should be shown to them. In regard to the divisions between the Christians and the common people, all alike are our people and subjects, and when there are law disputes the local authorities should adjust them carefully, and irrespective of class of religion, seeking only to discover who is really in the wrong and showing no partiality, in order that the people may realize the fatherly sympathy of the Throne. Let this be widlely published."

(Note.) It is curious to note the desire for fatherly sympathy towards these rioters, in contrast with the death punishment inflicted on the many who sympathized with the reform movement.

\section{The Viceroy's Proclanition}

which sets forth the above, adds:-

"It appears by the law that all idle persons who instead of attending to their duties devote themselves to teaching people fencing and boxing, and that all who go to them for such instruction, or those who give public exhibitions of fencing to make money and thereby excite the imagination of the people, are acting contrary to the law and render themselves liable to it. Such teachers are liable to arrest and banishment to $1,000 \mathrm{li}$, after receiving 100 blows; while those who go to them for instruction are liable to 100 blows and three years' banishment, and at the end of that time to be escorted by a guard to their native place and kept under observation. If shops, or inns, or monasteries shelter such persons without reporting the same, or if the Tipaos fail to arrest them, the law commands that they shall receive 80 blows. Thus to teach and practice boxing is punishable by law, and much more so is the ignorant misconduct of the people who become excited by ruffians from other provinces. Their teaching .con- 
sists of making charms and reciting spells by which the people become possessed of power to resist fire-arms. They believe this and organize the I-ho-ch'uan, and practice boxing and fencing, thereby extending their influence in all directions. They are known to oppose religions, make trouble and disturb the peace, and when the Government troops go to disperse them they dare to resist them. They have been notified by both civil and military authorities. Some appear to comply in the face of the officials, but continue their evil practices behind their backs. We regard all people, whether Christians or not, as children of the Government, and all disputes among them should be laid before the officials and left to their judgment. But the people do just the contrary. They collect mobs and burn down property, exact ransom and injure others, while resisting the Imperial troops and officers. Their actions are those of robbers and bandits. You all have lives and property, what profit is it to you to be excited to this foolishness and to wilfully violate the law? Strict orders are now given to local authorities to arrest such foolish fellows, and I hereby notify the gentry and every class in every district that all who gather people together and organize secret societies are breaking the law, and those who disturb the peace and rob violently cannot be excused by the law. All who erect sheds for boxing instruction or act in such a way as to cause a rising are authorized to be arrested and severely punished. All ignorant persons who have been tempted to join the society and practice boxing should repent at once, and discontinue their evil habits and become peaceful and loyal subjects. If they repent they will be pardoned for past fault, and if they do not but still continue their evil practices the local authorities will punish them severely without leniency. The common people and Christians are all subjects, and are to be treated with fatherly sympathy without distinction, but when disputes arise among them they ought to be submitted to the authorities. They should not presumptuously act on the dictates of angry feeling and give cause for offence. The Christians also should not make trouble to oppress the people, nor persuade the missionaries to give them protection in order to get the best of a suit. The local authorities should judge the cases according to law without distinction. Both people and Christians should occupy themselves with their own duties and avoid jealousy and suspicions, but give due weight to public harmony and peace. All of you respect this and obey."

Note the mild form of the proclamation, promising pardon for the most criminal offences in the past, and threatening 100 blows for what is really rebellion and trcason. The Edict has had no effect. Tientsin and Peking are surrounded by Boxers and enlisting as well as drilling goes on constantly. Boxer speeches are being made daily to immense crowds outside the South Gate of Tientsin city, and the people say of the edict: "It is foreign, and means nothing. It has been issued by the Viceroy because the foreigners paid him to do it. 100 blows is nothing to suffer for the privilege of driving out the foreigners and destroying the foreign religion." Then, too, the 
officials act on secret instructions, and not necessarily on Edicts of this nature, and its effect has thus far been mil.

Later.-The situation in the North is unchanged, except for the worse. The recent punishment of the murdercrs of Mr. Brooks, one by decapitation, one by strangulation, one by imprisonment for life, and several others, more or less implicated, by banishment, imprisonment and beating, has had apparcntly no effect in subduing the spirits of the Boxers. Late information from Linching and vicinity is to the effect that rioting has again broken out, the Boxers saying that they now want not money, but lives; and all over Chihli and Shantung recruiting and "drilling" is carried on with renewed vigour. The report that thousands of the Imperial troops are uniting with the Boxers (particularly those under Prince Tuan) adds a new and serious phase to the matter. What the real object of the I-ho-ch'uan (as a whole) may be-what the final outcome will be, cannot be stated. In some sections (comparatively few) the movement is wholly directed against Roman Catholics, Protestants being distinguished and undisturbed; in other sections it is anti-Christian, while in most sections it is anti-forcign, affecting missionaries, native Christians and foreigners generally: The Edicts of the Empress-Dowager to the people of Shantung, calling upon them to form as militia, for local and national defence, were doubtless the origin of the I-ho-ch'uan. The Germans had already located in a portion of the province, and the Dowager hoped, by stirring the people to opposition and a display of antiforeign feeling, to discourage their further encroachments. This is the view taken by many well-informed foreigners, and the inactivity of all the officials during the worst periods of rioting by the Boxers seems to bear out that opinion. The Government is now powerless and any active measures by the Empress against the society she herself brought into life and encouraged through her officials, would doubtless turn its energies and direct them to rebellion against the Throne. The lawlessness in Shantung resulted in driving the Germans to take the law into their own hands. They burned villages and punished local offenders, which in turn aroused hatred in the breasts of the natives, who were further incited to acts of violence by travelling leaders of the Boxers. "Exalt the Dynasty and kill the Foreigners" was their cry, and while no efforts of theirs could do the former, there has been and still is every promise of their doing the latter, though not as effectively as they desire. The Government was finally stirred somewhat by the fear of certain consequences that must follow the loss of forcign lives and property, and strove by mild and pacifying Edicts to stay the hand of lawlessness-but too late; for even had these Edicts been widely published (which they were not) the ruffians who had banded themselves together by Imperial command had gone too far to be content with anything short of plunder, the sight of burning homes and the flow of blood. Minor officials, believing. as they were taught, that inaction would best recommend them to the Throne, and fearing the roving bands that had assumed 
such vast proportions and displayed so much power, denied the very presence of Boxers in their districts, while at the same time bribing these bandits to go elsewhere and feeding them while they chose to remain.

The Boxers have thus been led to believe that they were carrying out the will of the Throne, and all Edicts and proclamations contrary to their motives have been taken as customary Chinese deceit, designed to "pull wool over the eyes" of foreigners. As the I-ho-ch'uan now stands, it is fearless and independent-strong enough (or scattered enough) to defy the Imperial troops (of whom many are in the ranks) if necessary, and self-confident enough to believe in its power to clear the borders of China of foreigners and foreign influence. There is unrest on every hand, the peaceful natives having more to fear than the foreign residents. Honest men who cannot but be acquainted with the plans and projects of the Boxers are silenced from fear of them, and thus their real plans and movements are hidden in mystery and no one can say whether the organization will gradually die out (which is very doubtful) or result in a general uprising or in open rebellion. We hope for the best, but indiçations point to grave results. But it is not alone the I-ho-ch'uan, or Boxer Society, that causes a grave situation and threatens rebellion and bloodshed. The Central Government, following out the mistaken policy of the Empress-Dowager, after the practical dethronement of the Emperor Kuang Hsu, has brought the nation to the verge of ruin, and is itself in such a condition that the next year, it would seem, must bring about some great and overwhelming change. Never, probably, in the history of the Empire, was the Imperial Government composed of such ignorant, greedy, anti-progressive men. One by one, the Empress-Dowager has replaced men of even slight intelligence or faint ambition by believers in her own evil policy-or whose greed for wealth or title led them to support her. These men have sold their loyalty (?) for the rank and power she had to offer, while she, intelligent in some ways, shrewd, but blind to the future, has thought to support her position and further her designs by the free-handed bestowal of rank and title upon evil men whose only desire is to line their pockets as rapidly as possible, forgetting or not knowing that every man thus bought replaced one who must be degraded and turned to hatred. For every friend she has purchased she has made at least two enemies, and as for her future good, she has no greater enemies than her friends. The degraded officials who have made way for men of her own chosing have, it is true, lost their rank, but not their influence among the people, and much may be expected from their efforts. The Dowager has not been content to surround the Throne with men "after her own heart," but throughout the whole Empire, by a slow but certain process, has filled almost every influential post with men after her own stamp. It is easy to guess what an influence one ignorant, conservative, antiforeign official may have, what seeds of evil he may scatter among his family, servants, friends and acquaintances, each in turn doing 
likewise; but who can estimate the power of the Empress-Dowager who controls and guides hundreds of men of this character? Each man thus appointed realizes that he now has an opportunity he may soon lose, for the rulers are fickle and every official has enemies, and so his one desire is to enrich himself as quickly as possible. He cares nothing for the 'Throne, beyond kceping its favour until his greed is satisfied; he refuses to sce or hear of danger to rulers or country, hoping, caring only that things may continue as they are until his own end is gained. Of patriotism he has none, but he hates the foreigner and fears foreign methods and influence, since they menace his power for gain, and this very hatred is his recommendation to the DowagerEmpress. He sow's seeds of discontent and fosters every form of evil -all for self. Circumstances absolutely forbid the existence of one honest official-one progressive man, in power. Above, below, on every hand he would be pressed by corruption and evil suggestions, and he must follow the wicked methods of others or be crushed, while one progressive move on his part would condemn him to the Throne and prove equally fatal, for the word "reformer" now means death. Never was Chinese officialdom so low-never were the confidential advisers of the rulers so ignorant or so opposed to every good thing. It would seem that the Dowager, in her downward course, must have sighted or scented the danger she was courting, but the men she has chosen to aid and advise her, bent only on gain, loving only self, have soothed her fears and encouraged her misplaced ambition. Good advice would, if followed, mean their own ruin, and why should they give it, even if they were not too ignorant and blind to do so? Two things, usually regarded as invaluable blessings, have but increased the power of the Throne for evil. I refer to the postal system and the telegraph, which now link together the provinces and favour rapid communication. Previous to their introduction it took weeks and sometimes months to deliver the Imperial commands in distant provinces, and the Emperor knew little of what was going on beyond the capital. But now all this is changed.

The spies of the Empress-Dowager are in every centre, and she is in touch with the feelings and doings of her people in every part of the Empire. The first step toward progress, taken by any official, however clistant, would be immediately checked by telegraphic orders for his dismissal, and the post would carry orders to his successor. The prescnt outlook is black indeed and one can only see in the future rebellion, strife. bloodshed, perhaps the actual break up of this ancient Empire. Despite the overwhelming wickedness, however, despite the innorance and superstition which darkens the lives of the masses and renders them an easy poy for malicious leaders, there exists some knowledge of the truth, some desire for reformation. The words of one enlightened man, in reference to the murder of six reformers by the Empress-Dowager, "They may cut the grass, but the roots remain." are true. "The condemation of the reformer I'ang Yu-wei and the limperor's old tutor Vang is not forgiven by the people of the South, who knew and respected them both, and the desecration of 
the graves of K'ang's ancestors, by order of the Dowager, cannot be forgotten or forgiven. Many saw a glimpse of light during the brief sway of the reformation which they cannot forget, and among intelligent natives there is a love for Kuang Hsu and a sincere desire for the changes he proposed. Then, too, the hundreds of officials thrown out of office and favour by the Empress are sowing seeds of opposition to the dynasty, and in the South there is every indication of rebellion, for the people there desire to see the end of Manchu rule and a Chinese on the Throne. These are the facts as they stand. Human wisdom cannot pierce the veil of the future, but the result of the increasing corruption in the Imperial city and in every important office, the lack of foresight on the part of the officials, the seeds of discontent that have been and are being sown, can have but one result-rebellion. The I-ho-ch'uan presents but one feature of a vast complication. It is but one mesh in the net of ruin that is drawing closer. The friends of progress are silent and concealed and the officials present a bitter front to the foreigner, because in so doing rests their own safety. Foreign newspapers in the ports and native newspapers under foreign control are forbidden to the Chinese, and reading them is made a crime, yet it is a sign that there exists an undercurrent of progress that two native newspapers, both in the foreign concession of Tientsin and one under Japanese control, have larger circulations than ever before, and they are very outspoken on forbidden subjects, throwing light on the worst acts of the officials and criticising daily the conduct of the Empress-Dowager. Hundreds of these papers go daily to Peking itself, and they must have influence for the good. It is a consolation to know that many are reading the truth they dare not show a desire to learn or listen to, and which they are forced to openly disavow. Something must come of all this, and that something will mean the overturning of the present dynasty or the dismemberment of China-or both. Should the Chinese rise against the Throne no one can estimate the bloodshed that would follow, nor can anyone guess what the attitude of the Powers might be. Throughout the ages the Chinese have exercised the right to revolt against unjust rulers, and at no time could such action be more justifiable than now. The Southerners are anxious for it-are preparing for it; the Northerners are indifferent to a great extent, and the Boxers are an unknown quantity. The future is unknown, but the present gives promise of unpleasant things. Meanwhile the combination of corrupt officials and the Boxer organization threatens all Christian work in the North-all progress of every kind, and we can only hope for the dawn of a new day. It is reported, and is to be believed, that General Yuan, the military governor who replaced the cival governor in Shantung, has received secret instructions not to use force with the Boxers, but to teach them that their ideas are a little mistaken. Tientsin is safe, but all stations, all Christians and all foreigners in the interior are in constant danger. The arrival of the U.S.S. Wheeling and other gunboats may have a quieting effect in this vicinity, but they cannot influence the people at distant points. 
We have all hoped that China might be preserved and saved, but with the Government in its present condition and rebellion imminent, the division of China seems inevitable, and as a last resource for the good of the people it may be welcomed.

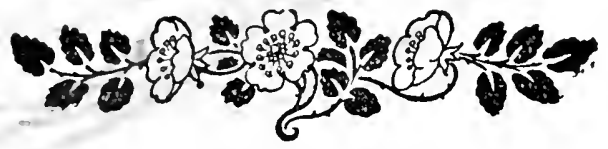




\section{THE BEGINNING OF THE OUTBREAK.}

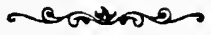

The following narrative of the earlier events in the North was sent to Dr. Hykes, of the American Bible Society, by the Agent of the Society in Tientsin on June 5th, I900:-

It now seems that we are to have the closing chapter of a movement second only to the great T'ai P'ing rebellion, although at this writing I can but mention facts that indicate the beginning of the end. It has been assumed by visitors to the North that the reports of Boxer uprisings have been grossly exaggerated; and to some extent this is doubtless true; but the events of the past two weeks have shown but too clearly that the Boxer movement cannot be regarded too seriously. For many months past Boxer bands have, with ever increasing malignity and power, committed countless outrages; but these being confined to native Christians have not given cause for strong action on the part of the Foreign Ministers, though they have done all that lay within their power to cause the Chinese Government to suppress the rebels. Men, women and children have been put to death outright after being robbed, or robbed and tortured, and in either case their homes have been destroyed; but to the casual observer these things have not been prominently in evidence. Disturbances, though frequent and plentiful, have been in distant and more or less isolated places, from which reports have been slow in reaching us and rendered untrustworthy by the transforming imaginations of the Chinese. For this reason visitors to the North have been deceived by surface appearances; and, while exaggerated reports may have been spread, many of these observers have been driven to the other extreme and pronounced a comparative calm where better informed people could detect the rumbling of a volcano soon to burst into flame. For two or three weeks past the situation has daily grown more serious, owing to the union of Boxers from various districts and a consequent increase in their power and daring. From many stations in the interior where native churches are established have come tales of persecution, sometimes confined to one man alone, and in other cases whole families and whole villages suffering loss of life and destruction of property. In view of the rapid and gigantic increase, both of the Boxers and their nefarious operations, we had come to look for a sudden crisis, and this we now seem to have 
reached. For a long time past Paotingfu and vicinity has been the centre of organisation for the Boxers, and it was near that city that a village of native Catholies made, from the roofs of their houses, a successful defence agrainst an attack by the Boxers, killing seventy of their number with but little loss to themselves. They had been proviled with shotguns, however, and this is exceptional, the natives being as a rule entirely helpless. It was therefore in the Paotingfu district that we expected the beginning of a great uprising, and in this we were neither disappointed nor mistaken. On Sunday, May 27 th, a large body of men, armed with knives, clubs and a few firearms, marched up the line of the Paotingfu Railway and began the wholesale destruction of houses, shops and railway stations. A portion of the line was destroyed, the telegraph cut, and by Monday morning six stations were burned, including the homes of Chinese residents and the shops of native merchants. A panic ran along the line long before the arrival of the Boxers, and the places destroyed ware mostly deserted in time to save life. Native refugees came pouring into Tientsin leaving their homes, shops and the property of the railway unprotected and univatched. At Feng-tai, the junction of the Peking and Paotinglu lines, there was a group of foreign houses (the homes of foreign railway employés), a roundhouse containing several locomotives, large car and machine shops, store houses, a small village of native houses and shops and a large station building, all of which were looted and burned, the residents fortunately escaping by train to Tientsin. It is said that genuine Boxers did not reach Fengtai, but that it was destroyed by coolies about the place, but this is a distinction without a difference, since many of the Boxers themselves are of the coolie class, and these were actuated by feelings of sympathy for this anti-foreign movement. These, and others like them, are Boxers in both heart and deed, and are fully as much to be feared. The news of this rioting and destruction brought temporary chaos to Peking and Tientsin. Immense crowds assembled at the stations and in the streets, eagrerly discussing the ever-changing reports that came from a multitude of sources. Excitement ran high and there was a general feeling of alarm-not for residents in either of these two cities but for the many missionaries and colporteurs in distant and isolated places, especially those in Paotingfu, with whom communication by rail and by telegraph was entirely cut off. Not until Tuesday could we learn of the action that harl been taken by the foreign ministers; then came the welcome news that troops had been sent for hastily. Application was made to the Chinese Government for permission to land marines and sailors from the men-of-war arriving and to quarter them in Peking, and when the Tsungli Yamen (Foreign Ofice) replied that Prince Ching must first be consulted, the Ministers sent word that with or without the permisciun of the officials they would land and station men in Peking. Almiral Kempp, on the U.S. Newark, had arrived at the mouth of the Peiho (6o miles from Tientsin by river, 30 miles by rail), on Sunday, but, knowing nothing of what was taking place, did not land 
men at once. The reports of Monday being confirmed, our Consul immodiately telegraphed the facts to the Admiral, who landed Ioo men, two machine guns and a field-piece within one hour after receiving the Consul's message. It ivas understood that the soldiers in the 'Taku Forts, which guard the river's mouth had orders to fire upon any foreign troops attempting to land, but our men passed safely in native boats and ware towed up the river, reaching Tientsin at I I p.m., where they received a rousing welcome by a large gathering of the foreign residents. With the exception of a small party of Japanese, who came during the forenoon, our mon were the first to arrive. On Wednesday, guards from the ships of five nations had landed here, and permission was then sought to send a portion of them ts Peking, but the Viceroy and Peking oificials put every obstacle in their way. The Americans, conducted by Captain McCalla of the Newark, had with them an engineer, fireman and machinists, and were fully prepared to take a train to Peking by force if necessary, and if this plan failed thret boats with double crews were engaged and ready to take them by river to Tungchow, from where they would have but sixteen miles to march to the Capital. On Thursday, however, the Chinese officials, finding further resistance useless, granted permission for 30 men of each nationality to go by train and station themselves at their respective Legations, and at 4 o'clock a special train conveyed them to Peling. The "thirty" men of each nationality were made up as follows: 75 British, 75 Russians, 75 French, 52 Americans, 30 Italians and 30 Japanese, while guards of like strength were left in 'Tientsin. Since then outrages in country stations have been widespread and terrible. Native refugees are fleeing here for safety, all of them leaving their homes in ashes and many of them after having seen parents, wives and children hacked to pieces by the heartless mobs. Many villages about Peking have been sacked and the Christians exterminated. A large proportion of the refugees were formerly prosperous men, but they are now dependent upon us for clothing and food, and as the number is hourly increasing the care of them will soon be a serious problem, considering our limited resources. Two more English missionaries, Messrs. Norman and Robinson, have been slaughtered. Mr. Robinson was killed soon after his capture, after having been tortured, while Mr. Norman was for a time held for a ransom of Tls. 40,000. Before terms could be offered or a rescue party sent out, however, he too was murdered. A party of French and Belgian engineers, with their wives and children, attempted to flee from Paotingfu and embarked for Tientsin on native boats, but the news of their coming went before them and they were obliged to fight their way desperately through every village. They killed a number of Boxers and received several wounds and were finally obliged to leave their boats and walk to Tientsin, which they did after three days, living on river water and rice. They reached here in a terrible condition, the ladies with bleeding feet and several wounds, and the men suffering from various injuries. Unfortunately some of their number had become separated and left 
behind, and there is no doubt these perished. A party of Russians (mountel) were sent out to find them but returned without success after having had a hand-to-hand fight with the Boxers, killing many and themselves receiving serious spear wounds. Since then the head of a Frenchman has been seen mounted on a pole not far from Tientsin, and later the bodics of the man and his wife were found, the woman having been terribly cut with knives. Four more of the same party are said to be among the missing. The missionaries at Paotingfu have thus far, and wisely too, refused to leave there. With the railway destroyed and boat travel certainly fatal, they cannot leave, and, with the Government so thoroughly helpless and the soldiers so thoroughly in sympathy with the Boxers, there is cause to fear for their safety, although the Minister has warned the officials to give protection.

The railway authorities are fighting hard to maintain communication with Peking (the heads of the departments being British) but the line is daily interrupted by the burning of bridges and stations, and trains are frequently returning, unable to get through. Three more stations have been destroyed in as many days and two bridges burned, each time a step nearer to Tientsin, and the line may be wholly destroyed at any time, leaving the Ministers and other foreigners in Peking entirely cut-off. The Chinese troops sent to guard the line have failed to accomplish anything and even if they were not in sympathy with the present anti-foreign movement and largely members of the Boxer Society there is every reason to believe that they have secret instructions not to resist or punish the Boxers. Meanwhile the Powers have been daily landing sailors and marines, and Tientsin is one great military post, full of moving patrols and with guards stationed at every vulnerable point. Twenty men-of-war are now at the mouth of the river and more are coming. Our own situation is comparativcly safe, although an attack is expected at any moment, the Boxers having assembled by thousands, coming in bands of 50, 100 and sometimes 500 , from every point of the compass. It is for the people of Peking, Paotingfu, Tungchow and other points in the interior that we are anxious. The Chinese are in a very excited state and to enter the city now would mean certain death to any foreigner. Reports are circulated that we have poisoned the wells and food and that we have cast spells on families and houses. Medicine to counteract these evils is sold at high prices and the forcigner is now both hated and fearel. Printed red circulars stating that we are using the cyes of children for medicine, and stories far more horrible, and calling upon all men to rise and "sweep the foreign devils into the sea" are being freely clistributed, inciting the people to more fanaticism and striking terror to the hearts of peaceful natives. It scems strange to walk the streets armed and to sleep with rifles, revolvers and belts of ammunition by the bedside, but that is what we are now forced to do. Perhaps the foe that we have most to dread in Tientsin is firc, for that we cannot fight with troops or gunboats. Repeated attempts have been made to fire prominent 
buildings, in some cases claborate preparations having been made. Three attempts to burn the Catholic Church have been discovered, one building in the heart of the settlement is in ashes after previous attempts to fire it, and an immense godown which was wet with oil and ready for burning has been saved only by maintaining a guard of soldiers about it, and this is also true of the hospitals. An extensive fire would render us helpless, but the river will in any case afford a means of escape. China has reached a critical state, and war with the Powers or a rebelion of great magnitude seems inevitable. The Empress-Dowager, a shrewd but overreaching and heartless woman, is now alarmed at the power of the Society to which she has given birth, fostering care and unlimited encouragement. She had hoped for the success of the Boxers in driving foreigners from the land, but now they have caused the landing of foreign troops without accomplishing their design and she dare not attempt to stay their hand lest they turn in rebellion; while, on the other hand, she realises that if their depredations continue the Powers will overthrow the dynasty, and perhaps divide the Empire. She has sown the wind and must reap the whirlwind. As for the Boxers, they believe themselves invulnerable to knives and bullets and the support given by the Dowager indicates that she too has faith in the spiritual protection they claim. I mentioned in a previous report the element of superstition in this movement, and suggested that the leaders exercised hypnotic influence on a few good subjects to draw the multitudes into their ranks. This supposition proves to be a fact. For ages past hypnotism has been known and practised by a few in China, and the Boxers have carefully sought out those who have this power to aid them in gathering and organising the masses in Boxer Societies. Naturally the Chinese explain this power in but one way-the subject is influenced by spiritual power, and the crowds, who gather to see a man under this influence squirm upon the ground and to hear the strange language he utters, believe all too readily that spirits indeed fight with the Boxers, guarding them from harm and aiding them in battle. What wonder that, safe from harm themselves, they are ready to fill the ranks for looting and destruction and bloodshed, especially when they are told by the officials that this is patriotism? That they really believe in this spiritual protection there can be no doubt. A few weeks ago three of these men applied at a military camp for enlistment, saying that they were Boxers and therefore bulletproof. One of the soldiers asked if either of these men would stand up and be fired upon and this request was willingly complied with, the soldier not hesitating to fire point blank at the man, who, of course, fell dead. This is faith indeed and it is such blind superstition that leads these men on to reckless daring. The leaders when recruiting give not only examples of hypnotism, but fire upon each other without injury, this being accomplished by trickery easily discernable by a careful observer. It is thus then that the Boxers find their inspiration and inspire fear in others. The soldiers also believe the same foolish tales and fear to really fight against the 
Boxers; the people believe and flee before them; they themselves believe and fear nothing. China then is helpless. "True, the Catholics killed 70 Bosers, and with bullets, but this was due to "lack of faith" or "improper organisation." Superstitious minds are not easily undeceived. From these facts it may be seen that nothing short of a great battle in which the Boxers meet with great loss of life will put an end to this uprising. The Chinese troops either fear them or form a part of them, or, as we believe, they have orders not to fire upon them, and it appears therefore that foreign troops alone will be able to accomplish the desired result. There our present knowledge ends, and we cannot see what the next few weeks will bring forth, but we do hope that in any case, this uprising, now one year and a half old, will be thoroughly put down. 'The weather has favoured these troubles, there having been but one shower of rain this year. The wheat crop is already dead and another week of dry weather will ensure a famine all over North China and millions of starving people. This will but encourage and strengthen the rioters, who may already be counted by tens of thousands. The heat is intense and the soil is parched. Surely China is suffering a curse and rushing on to her own destruction, and the end must be very near. An attack here would fail if the native troops would assist us, or even refuse to aid the Boxers, but a combined attack, such as there is a cause to fear, would be serious indeed, as the Chinese troops number tens of thousands, well armed. Fifty-five Americans are in our compound, and during the night they share with other foreign troops the establishing of outposts over the outskirts of the whole settlement. It is probable that ships and men are already on the way here from Manila to strengthen our forces. All nations are sending for additional men and unless the Chinese Government shows some signs of strength and determination at once, the Ministers will not hesitate to take matters into their own hands.

June 6th.-There is no change except for the worse. An attack is daily expected and outposts are being strengthened with the arrival of fresh troops. Railway communication with Peking is again broken and foreign troops may have to march to the Capital if our people are to be protected. It is reported that General Nieh's troops fought the Boxers yesterday, killing many, and the Chinese say that he stationed field suns behind his men and told them that unless they fought they would be fired upon from the rear. This may be partly or wholly untrue, but it is characteristic of the Chinese, and were I at all inclined to believe that the troops fought at all, I should be equally inclined to believe the latter part of the story as well. Another railway station was burned last night, although 4,000 Chinese troops were sent up the line yesterday. 'This fact speaks for itself. Reports of the slaughter of Christians and looting and burning still come in from all directions and refugees still arrive with harrowing details. Since names of small places would convey little information and details of outrages would only prove revolting, I need not specialise-enough has been said to show the existing state of affairs and the seriousness of it all. Some 
Christians have recanted to save their lives and have been saddled and bridled and forced to crawl to the the temple idols, while every indignity has been heaped upon them, but, be it said to the glory of the Church in China and the power of the Word, that hundreds have given their lives for Christ's sake, and have been true and steadfast to the end, while others have not hesitated to join the church to share in the persecution. We know not what an hour may bring forth. A reign of terror is about us and tales of slaughter and cruel tortures make us heart-sick.

Following is a list of the foreign troops that have landed up to this date. Twenty-five Americans are expected to-morrow, and 400 U.S. marines are looked for from Manila. I will report further developments from time to time.

Troops landed in Tientsin from May 3oth to June 6th:-

British 296, American 175, Russian 150, French 140, German 412, Japanese 100, Austrian 31, Cossacks 60.

Of these over 400 are at present stationed in Peking, and in Tientsin we have some 800 , besides British and German volunteers (residents) who number over 100. Twenty-eight men-of-war lie at the mouth of the river.

June 7 th.-Twenty-five American marines from the U.S.S. Monocacy, are landing this morning. Two men-of-war have arrived and are also landing men. An elaborate defence of the settlement has been arranged for, and the streets are barricaded. The railway tracks have been torn up and as the employés have deserted the stations no details of the damage done has been received, nor can repairs be made. Peking is therefore cut off for the present. The Chinese troops are reported to be fighting and if they really do good work they may succeed in checking the rebellion.

June 7 th.-This morning I mailed you a report which I think covers all recent events, except that many details were necessarily omitted. This afternoon the next station on the railway to Tientsin was burned so that Tientsin station will be the next to go- - if. We only fear that they will not attempt it, for if they do our men will give them a much needed lesson and one that will have no little effect in changing the present situation. We have learned that General Nieh's troops did fire on the Boxers, but took good care that the shots went over their heads. The soldiers who went to defend other stations (which were burned) left without ammunition. This settlement is safe from attack, as there are nearly a thousand soldiers here; yet they have so much ground to cover and so many streets to protect that a combined attack (Boxers and Chinese troops) would be very serious. Hundreds of refugees have come in to-day, especially Catholics, and many places in this vicinity have gone up in flames. Most of our men have reached Peking in safety. I enclose copy of a recent placard and also extracts from a letter received to-day from Paotingfu. Those who are there and in Tungchow are in serious danger and now the telegraph is cut and we cannot hear 
from them. I shall report day by day if necessary to keep you well $i_{\text {nformed. The Legation ladies tried to leave Peking to-day but it was }}$ too late. It is believed that a train with troops (probably British) will work its way up the line to-morrow, and it may reach Peking as they will have constructors with them. If only these Boxers meet with foreign troops they will get a set back-until then they will keep right on.

Translation of a placard, a sample of many varieties, of which 200,000 copies were distributed in Tientsin city on June 4 th. Only the prompt arrival of the foreign troops prevented a second Tientsin massacre:-

\section{SACRED EDICT.}

ISSLED BX TIIE LORD OF WEALTII AND HAPPINESS.

The Catholic and Protestant religions being insolent to the gods and extinguishing sanctity, rendering no obdience to Buddhism and enraging both Heaven and Earth, the rain-clouds now no longer visit us; but $8,000,000$ Spirit Soldiers will descend from Heaven and sweep the Empire clean of all foreigners. Then will the gentle showers once more water our lands: and, when the tread of soldiers and the clash of stecl are heard, heralding woes to all our people, then the Buddhist's Patriotic League of Boxers will be able to protect the Empire and bring peace to all its people.

Hasten, then, to spread this doctrine far and wide; for, if you gain one adherent to the faith, your own person will be absolved from all future misfortunes. If you gain five adherents to the faith, your whole family will be absolved from all evils; and, if you gain ten adherents to the faith, your whole village will be absolved from all calamities. Those who gain no adherents to the cause shall be decapitated; for, until all foreigners have been exterminated, the rain can never visit us. Those who have been so unfortunate as to have drunk water from wells poisoned by foreigners should at once make use of the following Divine Prescription, the ingredients of which are to be decocted and swallowed, when the poisoned patient will recover:-

Dried black plums.................. half an ounce.

Solanum dulcamara ................ half an ounce.

Encommia ulmoides (\%) ............ half an ounce.

Extracts from an undated latter from Paotingfu, received in Tientsin, 7 th June:-

"Our position is dangerous-very. We are having awfully hot, dry dusty day's and y'ao y'en (rumours) are increasing. Everything is turning from killing of Catholics to taking in both Protestants and Catholics. Talk now is definite that Nan Chuang, 30 li south, is to be sacked to-morrow or next day - then the Roman Catholic church 
here-and then our place. Oh that God would send rain. That would make things quiet for a time. No soldiers here to amount to anything-no good anyway. They frankly say that they have orders not to fire at Boxers. We have a guard of ten-ready to run at any time. We can't go out and fight-we must sit still, do our work, and if God calls us to Him, that's all. Unless definite orders come from Peking that we are to be protected at any cost or a guard of soldiers (foreign) sent at once, the blood must flow. We are trying to encourage the brethren, but it is difficult work. A crisis must come soon-the Lord's will be done. I send this by special messenger to Peking. The railway to Kao Pei Tien is all right. A guard from Peking ought to meet us in two and a half days. Telegraph to Shansi is cut. North of us 160 li are raiders, East 160 li on the river are the French murderers, South 50 li plunderers, south-west 60 li railway destroyers. Boxers plenty here-one spark from north, south, east or west and we are gone."

Tientsin, 9th June.-While there is nothing definite to report, matters are hourly assuming a more serious aspect. At this writing the Boxers have reached points three miles from Tientsin, in all directions, and it seems as if an attack on this Settlement were inevitable. Despite the number of regular troops here and the uniting of all foreigners into guards to assist the ladies to some central point, it is to be feared that an attack would have a disastrous result, since the rebels are sure to pour over fences and walls and mass the streets to such an extent that the troops here would have to be greatly divided up to cover so large a territory, and that would weaken them considerably. Everything now points to a war with the powers, since the Edicts from the Empress-Dowager still pat the Boxers on the back, and General Nieh, the only man who has really tried to do his duty, is to be reprimanded, while Tung Fu Shiang, the most antiforeign General in the army, and the one who has done most to foster the Boxer Society, is to be at the head of the troops sent to restore order. That the soldiers have distinct orders not to fire upon the Boxers is proved in many ways.

The foreigners at Tungchow have reached Peking in safety, escorted by U.S. Marines, and by this time the College and buildings there are doubtless in ashes. Twenty Christians were killed at the last report, but there are many more who must have suffered. We have no news from Paotingfu, and fear for the people there. It is too bad that foreign soldiers cannot be sent to rescue them. The last news was several days old.

Tientsin, Ioth June.-Late last night telegrams were received from the Mïnisters that matters looked very serious in Peking, and asking for the immediate despatch of troops by any and every possible means. A Consular meeting was held here at midnight in which the naval officers of the defence took part, and it was decided to take, by force if necessary, the railway, and to run a train through by constructing the line. Early this morning the troops were on the move, and two trains, with rails, sleepers and constructors, 
and carrying a thousand troops with large supplies of ammunition, field-pieces and machine guns, were sent off. 'The Viceroy finally gave permission for the use of the railway, but they may meet with opposition either on the way or at Peking. It is understood that the Ministers consider their lives in danger, and that if the troops get through, all the foreigners there will be sent to Tientsin. 'The Russians and French last night refused to co-operate, but this morning there were no less than four hundred Russians to go and a large number of French, as well as Italians, Austrians, Americans and British. Five hundred British were sent, and we sent the one hundred men who were here from American ships, making I50 Americans in Peking when they get there. Five hundred British and many Russians, etc., have arrived from Tongku, and more are to follow, while it is supposed that fresh troops will be sent to Peling as fast as men can be brought and trains made ready. In the meantime we have no less than fourteen hundred troops in Tientsin, with more to come. This looks very much like business, but if the Chinese troops resist it will be serious, as there must be at least 100,000 of them about Peking, though it is said that only three Generals out of the five in command will fight with the foreigners. There are but Twenty-five Americans in Tientsin now, the men from the Monocacy, but troops are expected from Manila, and the Helena will probably be forced to the Tientsin bund. Matters may be settled peaceably, but it all depends on whether the Chinese allow these trooys to enter Peking without resistance. The Viceroy's interpreter thinks that a protectorate might be established by the Powers without any trouble at all, but that is doubtful. There are fourteen miles (probably) of rail to construct, so that the trains with troops may be two days reaching the capital, but with Capt. McCalla in charge they will gret there.

Tientsin, I I th June.--This week has been filled with rumours and alarms. History, too, has been made. Some sad pages have been written in blood. The names of Norman and Robinson have been arlded to the roll of the noble army of martyrs, and the names also of hundreds, if not thousands, of humble native Christians, many of whom would have saved their lives by recanting; but who have preferred to die for their faith in Jesus Christ.

The line to Peking has been wrecked again and this is the seventh day since trains were ruming. On Thursday for several hours seventy British Marines waited at the Station for permission to go up and repair the line and re-open communications with the Capital, but the officials refused. They and hundreds of others, however, left yesterday, and already they have got to Langfang. Two thousand altogether have gone, some four hundred Russians having left this morning, and now we hear of two thousand Russians likely to go over the repaired line and reach Peling with the others :- for what?

The Edict published on the Ioth was simply abominable, and all Chinese who read between the lines can see how the Guvernment 
wholly approves of the patriotic Boxers and will by no means hurt a hair of their heads, for all the trouble has been caused by the Christians (?). Whereunto will this grow? Already the movement has attained such momentum that all Chihli seems involved and news comes of Shansi being likely to join the holy war, but what wonder when the father of the whole thing, dismissed from Shantung, is made governor in Shansi !

The call for a Home Guard was loyally responded to, and, out of our small community of those who were not already volunteers, over ninety responded. Their duties are to remove the women and children who are outside the concessions to the Gordon Hall whenever the alarm may be given, and then to do whatever may be appointed them by Mr. WW. Anderson, who is at the head of the movement. Some are unarmed, but the information supplied by each member showed that a very fair resistance could be made by the whole number in the way of arms.

Great sympathy is felt for the American Board Mission in the loss of their buildings at Tungchow and with the Missionaries, several of whom have lost everything. And will there be compensation if the Government breaks up? is the question that many are asking, and asking too, in the possibility of an attack, here.

Tientsin, 1 $3^{\text {th }}$ June.-All merchandise from the interior has stopped coming, and merchants here have instructed their Shanghai agents not to ship to the North; so that trade is dead, and there will be few steamers coming this way. Grave fears are felt for the people in Peking. A recent arrival reports that the streets are filled with "Boxers" who stalk about wearing the red girdle and bearing huge knives. The missionaries are together in the Methodist Compound, while the Ministers have joined forces in the British Legation. If the troops sent up meet with resistance, there may be a general massacre, but personally I do not fear this, though many foreigners do, and the Chinese speak of it as an assured fact. It is rumoured that Russia will protect the Chinese Government and that would be a serious business, but it does seem as if the matter ought to be settled peaceably. We can only hope for the best. It is evident, however, that all ladies will have to leave here, and many are making preparations for departure. If the Peking people only get down in safety there will be less to worry over. Of the trains loaded with troops we have little news. Yesterday they were reported to have reached Lang Fang, half way to the Capital, and we hope they are in Peking by this time. I believe the Boxers have given them a free trackcertainly there can have been no fighting or we should have heard of it. Captain Bailey is now in charge of the Tientsin force, while our Captain McCalla has gone on with the Peking force. Yesterday when they wanted to send another train load of soldiers from here, Director Tong said he had orders not to allow them to go, and when Captain Bailey ordered his men to take a train, Tong ordered his workmen to tear up a section of track in front of the cars. Captain Bailey merely turned to his men and said "fix bayonets." An engine 
was taken by display of force, and the men got off. Tong said, "Do you know I am Director of this road?" to which Captain Bailey replied, "I don't care who you are. If you interfere with me I'll hang you."

Some interesting facts have leaked out regarding the midnight meeting of Consuls and officers which led to the sending of troops to Peking on Sunday. It seems that during the conference the Russian and French representatives frequently drew apart for private conference, which was anything but polite or frank, and the Russian Colonel kept drawing attention to the fact (?) that no invasion of Peking ought to be made with less than I0,000 men (Russia being the only country that could land so many at short notice), and it became evident that he was hoping the others would say, "Well, you have the men, get them and go on." Of course the others would consent to no such thing, and so Russia and France finally refused to join the others in sending men-albeit they had troops at the station promptly in the morning. At last Captain McCalla said, "Well, gentlemen, you have talked this matter over pretty thoroughly, and have come to no decision, but l'll tell you what $\mathrm{I}$ am going to do; my Minister is in danger, and I am going to Peking." "There was then nothing left for the others but to follow, which the British were only too glad to do. Captain McCalla has earned the praise of all British and Americans here by his clear insight, prompt action and thoughtfulness. He has been on the go day and night, and all that has been accomplished has been mainly due to his steady perseverence. Captain Bailey, the British commander, is a man of the same stamp, both men that we may be proud of and in whose care we are sure of every attention and positive safety. A telegram yesterday informed us that the poor old Monocacy is to come here after all-and we need her. The assembled battle-ships, cruisers, gumboats and torpedo-boats at Taku present a wonderful sight. 'They are in as far as they can get, while in the river and past the Forts are two British, two Russian, one Japanese and a German-all gunboats. It is reported, not only that England has been invited to act with the United States in this matter, but that the German Emperor has sent orders for his forces to act with England. If this be so, and Japan is to be counted in, I do not see that Russia and France can interfere much. I anticipate no attack on Tientsin now, although the Chinese insist that there will be one, and have set the 23rd (Chinese) as the date. Only the arrival of troops averted a serious massacre here; there can be no doubt of that, but I do not believe they will want to face the number of soldiers we now have. Word from Chefoo has come that that place is full of Boxers, and the Yorktown is to be stationed there. No doubt the movement will reach Shanghai in due time, as its spread is now wonderfully rapid. Shansi is affected, and it is coming out anew in Shantung.

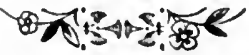




\section{THE SCENE OF STRIFE.}

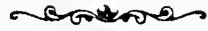

The following account of events at Tientsin was written by the "Shanghai Mercury" Correspondent on 15 th June:-

The end of this crisis seems by no means near. The policy of the Imperial Government seems still to be that of encouragement towards the Boxers. They are said to be parading openly in the City here, with their red girdles and red lamps, and the officials take no notice. The panic and fear among the Chinese is intense, and removals from the Settlements continue in great numbers. Servants are leaving and tradespeople, and it is difficult to get anything done.

The Station is the great place of concourse for natives and foreigners alike. Almost every train brings some troops or guns and stores. The arrival of the Russians yesterday created the greatest stir. Their magnificent horses and big guns; the wagons, and piles of hay and stores, took up all the big platform for the greater part of the day. They took possession of the Bridge leading into the Settlements and strengthened it for the passage of their guns, and for the time regulated traffic as if they had come to take charge entirely.

The streets are swarming with men in uniforms and at every few yards we meet patrols or see men on sentry duty. Little fear is felt for this place now. No Chinese is allowed to go out without a lamp nor pass the lines without a permit after dark. One poor huckster returning home and perhaps not understanding things, upon beingchallenged by the German sentry ran, and was at once shot dead! This seemed to most of us very like murder.

The railway to Peking is much more seriously damaged than was at first supposed and very slow progress is being made. No news whatever came from up line yesterday, and some people were fearing that the line had been again destroyed in the rear. The force only consists of about 2,000 men all 'told, and it will be difficult to guard their communications. The Russians, it is said, will march and thus get there first.

For three days now communication with Peking has been cut off by telegraph and rail alike. We hear of the murder by Chinese soldiers of the Secretary of the Japanese Legation; of tumult and danger; of preparations to resist the advancing allied forces; of 
30

THE BOXER RISING.

concentration of Chinese troops at Fengtai; but confirmation of these and hundreds of other stories is very difficult to obtain. perhaps war being upon us in a few days, most people, in view of some stock of things, while others are contemplating refuge in Japan or Shanghai or elsewhere if refuge is to be found in this little planet
which may so soon be torn asunder by the great European war night the national hymns of the nations represented here, and outwardly all is peace and amity. 


\section{EYE-WITNESS'S NARRATIVE.}

The following account of the events at Taku was given to a Representive of the "Mercury."

On Saturday, the 16 th June, the residents of Tientsin, though anxious, were in no way alarmed at the situation. They had a large force of marines within the limits of the Settlement, all business was at a standstill, and the Volunteers were on duty, but there was no expectation of great trouble, these precautions being more to keep the rabble in order than for any other reason. At that time there was no reason to fear that the attack which we now know has since been made by the Imperial troops would occur. So little fear was there that only a very few of the ladies resident in the port left for the South, these being principally visitors.

In Taku, however, the matter assumed a more serious aspect, and it is from this source that we learn for the first time what it was that led up to the taking of the forts, and the subsequent defiant action of the Chinese troops. It was learned early on Saturday that orders had been received from Lutai, whither the foreign-drilled troops which had had a fight with the Boxers a few days before, had retired, to send a train from Taku to convey between six and seven thousand soldiers, with about sixty field guns, to Taku. This coming to the ears of the foreign commanders with the men at that place, they forbade the despatch of the trains, and a detachment of marines was placed in the station to see that the order was not carried out. Evidently this action was telegraphed to Lutai, for a few hours after word was received that the force was marching overland to the place. The foreign commanders held a consultation, and as it was deemed inadvisable that this force should be allowed to enter the forts under the circumstances, notice was sent to the commander of the forts that as a matter of safety they would be occupied by the allied forces, and that if this was not allowed peaceably they would use force. Beyond replying that they would not allow the occupation, there was no word as to the fighting intended, so that when the forts opened fire on the fleet at I o'clock on Sunday it came almost as a surprise. However that may have been, we know that the position was easily taken, and that the cost was nothing like what might have been expected.

In the meantime the telegraph line leading into Taku had been cut, and also one of the telephone lines, though there was one of these still working $\left(17^{\text {th }}\right.$ ) to Tientsin. During Sunday afternoon word was 
received that there had been an attack by the Boxers on the Settlement, but that this had easily been repulsed, and that all was quiet then. $U p$ to that time the railway was in order, though it was not found practicable to run trains. However, an armoured train had grone out to see how things were at 'Tientsin, and up to the time our informant left 'Taku this had not returned, and it was feared that it had come to grief, probably at one of the bridges.

The above statement regarding the forces which were marching from Lutai probably explains the attack on Tientsin. These six or seven thousand troops did not reach Taku, and they were probably diverted by the new's of the capture of the forts to the larger city. They were probably joined by the troops which managed to escape from the forts, so that there might easily be eight or ten thousand more or less well drilled and armed men in the force which attacked the foreigners, and these had at least sixty field-pieces, which would account for the bombardment that occurred.

It is very difficult to learn how many defenders there were at the two places. The large men-of-war outside the Bar had landed all their spare men, and these were divided butween Taku and Tientsin, while the forces in the latter place had been still further reduced by the additional men who formed the relief column marching on the capital.

From a private letter, dated Chefoo, the 2oth, we learn that the s.s. Shengking has been engaged by the British Government as a transport and hospital ship. The Taku Hotel has been turned into a Hospital for the wounded at that place and was being guarded by marines. Many of the houses in Taku have been badly damaged by shell fire, and a few shells fell in the compound of the Hotel but fortunately did not burst. The new City forts were to be attacked on the 2oth, but the letter of course stated nothing of the result. There are thousands of foreign troops pouring into Taku, and about two thousand were landed there on the 19th. All the 'Taku women and children were sent away to Chefoo, and as soon as passages could be secured they came down to Shanghai.

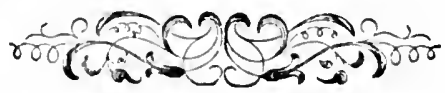




\section{STORY OF THE TAKU FORTS BOMBARD- MENT.}

By the courtesy of Mrs. James Jones, the "Shanghai Mercury" was enabled to publish on June 2 Ist the following account of her experiences in Tientsin and during the taking of the Taku Forts:-

Having just returned from a flying visit up north I send you a short account of the trip and experiences connected with it, as it may possibly interest you and some of your readers. I left Shanghai in the s.s. Hsinfung on Tuesday, I 2 th instant, for Tientsin, where, according to wires received, things were very unpleasant owing to the Boxers. After passing through a fleet of about 3I war-ships outside the Taku Bar, which made a splendid show, we finally reached Tangku on Friday in time to catch the last train leaving at 5 p.m.

On arriving at our destination ( 7.30 p.m. one hour late) we were very much surprised to find the station simply crowded with sailors and marines, all fully armed and mostly Russians, some being well mounted on horses brought over from Port Arthur. On proceeding on our way similar sights met us, marines and sailors of all nationalities on guard everywhere, and quite prepared for a sudden attack. At the house where I was to stay I found that the place was apparently in their possession, about 50 Austrians being put in the godowns adjoining the premises, whilst two of the officers occupied rooms in the house. After having dined, a party of us, escorted by a naval officer, took a short walk before retiring to rest, and then we saw what precautions had been taken for our safety. At every few yards we were challenged by a sentry. There was not a single Chinaman to be seen about and the whole place seemed still and deserted and very unlike Tientsin, especially the Taku Road, which is as a rule, I believe, one constant flow of traffic. Just as we were returning we heard seven shots fired in rapid succession, but feeling quite safe with so many protectors near we retired to rest. Not, as it happened, for long. At about midnight an officer came with the news that the whole of the Chinese city was in flames, that the Boxers were advancing and were then actually fighting at the Tientsin Railway station, which place they had also attempted to fire. We 
were told to get up and dress, so as to be in readiness to rush off to the Town Hall on the alarm being sounded.

The fire was a tremendous blaze and a really grand sight. It is reported that the city was fired in fourteen different places, and if the wind had been in the other direction Tientsin would have stood but a poor chance. When ready, we spent most of our time in the garden (the alarm not having sounded) beside the ammunition, which had been carried out there in case of the buildings being fired. Ten men were left to guard us, and the rest went off with their officers to meet the Boxers. It was about three o'clock when we were at last told we might safely retire agrain, as all was quiet, the Boxers having been driven off. We heard about 60 or 70 had been killed, but the number is uncertain. The firing had been very frequent since about I I p.m. and that and the barking and howling of dogs around gave one an unsettled feeling, so that we did not retire but just lay down as we were.

It was fortunate we did so, as at 4 a.m. we were hurriedly called up and informed that the Boxers were close upon us, advancing towards the back of our dwelling, and we were to go off at once to the Town Hall. As you can imagine in a very short space of time we were on our way there. The poor children were taken out of bed and hurriedly put into thick coats and shoes, and off we rushed to the Town Hall, where we found others similarly attired. It was a truly pitiful sight, there were so many little ones, some only a month old, and although they were very quiet and good, there were a few little white scared faces. Very few amahs were there, as most of the servants have run away, in some cases not one being left in the house. We remained at the Hall until about 7.30 a.m. not knowing quite what was happening or had happened during the time we had been there. Of course, all sorts of rumours were going round which did not tend to improve matters. At last word came that it was safe to return to our homes. The Boxers had withdrawn but would return that night, and they expected to have a big fight. All the women and children were strongly advised to leave, but then the difficulty arose of how to get away. The lines had been tampered with and the trains were not running. The damage to the lines, however, was evidently not so bad as reported, as it was quickly repaired, and at 2 p.m. as many as could get away left for 'Tangku, a pilot engine groing on ahead. Later on another train arrived, also with a number of ladies and children, and made for the various ships in port.

Even here our troubles were not at an end. We seemed to have fallen "out of the frying pan in the fire," for soon after getting on board we heard there was a probability of the Taku Forts being taken that night. It appears that the naval captains had called on the Gencral of the forts, taking Mr. Johnstone, a good Chinese scholar, as interpreter. and informed him that unless they surrendered by 12 oclock that night, they intended to bombard the forts at 2 a.m., it having transpired that thousands of soldiers were entering them and also laying mines across the channel during the day. In con- 
sequence of this the residents of Taku received orders at 6 p.m. to leave within an hour's time and take refuge on board the U.S.S. Monocacy, lying at the railway wharf. About I a.m. the Chinese opened fire, the first shot passing harmlessly through the Algerine rigging. From this time till about 6.30 a.m. was an unceasing bombardment, the roar of the cannon being almost deafening. The first fort taken was the North, by we presumed the Japanese, as that was the first flag we saw hoisted, followed shortly after by the British on the Outer North Fort.

After taking these forts the men-of-war steamed towards the mouth of the river and soon after the German and Russian flags went up on the South Forts. Shortly after daylight we saw four torpedo boats being towed in stern first by the Whiting and Fame, flying the British flags. During the time of bombardment we and the ships at Tangku were right in the line of fire and had anything but a pleasant time, the shells whistling above and around us in all directions, and the marvel is that the Monocacy was the only one struck, she receiving a shot right through her bows. The Lienshing, lying at Jardine's, besides running the risk of shells from the forts, was attacked by a party of Chinese who were looting the cargo, but the return fire from the Lienshing eventually drove them away. A shell falling into one of the Tangku hotels near the Railway Station killed three Chinese, the only ones that were in the house at the time.

About 10 a.m. when all was quiet some of the officers of our ship went off to explore, Mr. Conley going to the North Fort, Mr. Burgess to the South, and Mr. Miller to Taku, to see how the foreign residences had fared. On their return they had most ghastly tales to relate. The forts were a mass of ruins, rivers of blood, with headless and armless bodies everywhere, which the blue-jackets were gathering together and cremating in heaps.

Several of the houses at Taku were complete wrecks and nearly all had suffered in some way. As soon as it was daylight we saw in the distance a black mass of Chinese hurrying from the Forts and the villages round about. It is feared they will make for Tientsin and join the Boxers. Ae we passed down the river on our return we noticed the Russian flag was flying at the Imperial Dock at Taku, also on a destroyer lying in the Dock. We do not know how many Chinese were killed, but near the Tientsin Railway Station we saw several corpses lying round, the result of Saturday night's fight, a sight none of us are ever likely to forget. Among the navy the casualties were :-

British-Algerine-one officer killed, one officer badly wounded, three men killed.

German-Iltis-commander badly wounded, some men killed through explosion of a boiler, some men also wounded.

Russian-Bobr-no casualties.

Russian-Koreetz--two officers badly wounded, eight men killed, twelve men badly wounded.

Russian-Gilyak-one officer wounded, eight men killed, ten 
men badly wounded, seventy men burnt through explosion in powder room.

French-Lion-one officer killed, one man wounded.

On passing through the Fleet outside the Taku Bar on our return it made us all feel very sad to see the flags on every ship half-mast. It brought before us the horrors of the previous night, and made us think, not only of the poor fellows who had lost their lives but also of the unfortunate ones left in Tientsin. The difficulty there is getting away, as it it impossible to leave on either boat or train without a guard. A few residents did start for Tangku, but soon after leaving the crews deserted them. The trains are most uncertain and it is not always possible for people to leave, owing to the many attempts to wreck them.

An armoured train that ran during the night for the protection of the line, on the night of the bombardment did not arrive as usual nor had they heard anything of it in Tientsin up to the time of our leaving. Great uneasiness was felt both there and at Tangku at its non-arrival.

Another trouble is the scarcity of food, it being impossible to get any fresh meat, all the Chinese stores being closed; tinned provisions from the Foreign ones seem to be the only things procurable.

Before closing I should like to express my gratitude to all those who showed us such very great kindness. To Capt. Indrach and Lieut. Lachanovchy of the Zenta, who, when our servants deserted us, sent sailors to wash and cook and did everything in their power to cheer us up and help us. To Capt. WVise of the Monocacy who met us at the 'Tangku Station and whose servant looked after our baggage, and last but not least to Capt. Warwick and his officers, who readily gave up their cabins and have been kindness itself all through these trying times.

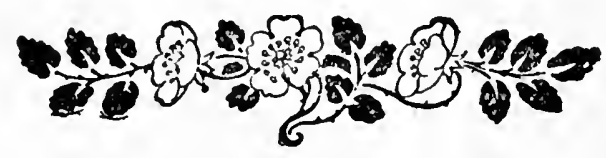




\section{THE LADIES AND CHILDREN AT TAKU.}

A lady resident of Taku, one of those who were driven out by the bombardment of the I7th ult., has given some details of the position there on those eventful days, which may be of interest.

Of course there had been considerable talk about what might be expected, but up to the afternoon of the I6th June there was no change in the routine of life there. Some of the ladies were playing tennis, and others were visiting friends and having afternoon tea, when word was brought by some of the gentlemen that it had been ordered that they were all to take what they could put into a small box, and prepare to go on board the Monocacy. This preparation took about an hour, the ladies passing down to the tug accompanied by their husbands or other gentlemen, some of them carrying their babies; and as there had already been an exodus of Chinese servants, there was a little trouble about having their things taken to the landing. When all were accounted for and the tug well loaded with goods, a start was made, and they were all taken on board the Monocacy, which was above the Forts, and here every effort was made for the comfort of the unexpected visitors. Every man on board was as good as could be, and even the sailors did as little as they could that was calculated to disturb the babies. Ot course, sleeping places had to be rigged up where possible, and the ladies prepared to make the best they could under the circumstances. When at I.5O by the ship's clock the first gun was fired from the forts, there was a general uprising, and many of the ladies were greatly scared. However, they were reassured by Captain Wise and his men, and, beyond the terrible sounds of the conflict, and the uncertainty as to what was happening to their husbands and 'friends, many of whom they knew must be on the ships assisting them to find anchorage and navigate, there was not much amiss.

During that night the Monocacy was neutral, and it was hoped that the ladies could remain there; but with the morning news was brought that American interests had suffered and the Captain found that he would have to enter into the fight. The ladies were therefore told they would have to go to a merchant steamer outside the Bar, and they were hurriedly packed into boats, while the ship was being cleared for action. When they were all in they were taken in tow and landed on a steamer there, by which they were conveyed the same day to Chefoo. 


\section{ADVENTURES OF TONGSHAN REFUGEES.}

A member of the staff of the "Shanghai Mercury" had an interview on 26 th June with two gentlemen who have been connected with the railway in the North since its inception, and who have only just arrived here from their posts, having been forced to leave on account of the threatening state of affairs there.

One of these grentlemen was at Tongshan, and on account of the rumours which were prevalent there, left that place with the intention of getting down to 'Tangku, on the morning of the 17 th inst., by a special train. When he had got as far as Lutai, he was informed that the bridge over the Hanku River, about twenty miles from Taku, had been destroyed and that he could go no further. He was here informed that the General in charge at Lutai had neceived information that the foreigners had the previous night taken the forts at Taku, and that all communication betwcen that place and Tongshan was cut. Upon hearing this he at once returned to Tongshan, were he found the foreigners preparing to retreat to Peitaiho. At the railway works there, where there are a large number of shops-machine, carpenter, foundries, etc.-there were a large number of Chinese workmen, these beidg mainly southern men-Cantonese, Ningpo and Shantung men. These were not inclined to make trouble, but they were much exercised by the numerous reports that were in circulation, and those who could were anxious to get away as they feared trouble. There were rumours of what the soldiers in the vicinity would do, and these decided the foreigners, of whom there were about fifty, in addition to the guard of fifty marines, which had just reached them, to leave for Peitaiho for safety. Accordingly; an engine was got ready, this being turned into an improvised armoured train by the men there, and then, without informing those up the line, and after, in fact, having themselves cut the telegraph wires so that no news of their movements could be sent, the party consisting of all the foreigners there, left silently, and, not without some few difficulties, but without great adventure, they reached Peitaiho on the evening of Sunday, the 17 th June. Our informant thinks that had some of the camps of soldiers which they passed known that they were fleeing they would certainly have wrecked the train. As it was they got through safely, and found the storeship) Humber at anchor there. The Humber was not able to accommodate 
all the refugees, and besides many of the men thought that matters were not so serious as it afterwards proved, so that the marines with Major Parsons, Mr. Kinder, and a number of the civilians were left behind, they intending to make an effort to return to Tongshan. The Humber, with the rest of the foreigners, left Peitaiho on Monday morning, the ISth, for Taku, where they arrived safely on Wednesday, the 2oth. Here it was first ordered that they should go to Chefoo on the Barfleur, but owing to later news of a fresh complication it was found impossible to make this arrangement, so that the refugees were hastily transhipped to the Yiksang, and on her they arrived safely at Chefoo, and thence came on down here.

These refugees are extremely grateful for the kindness shown them by all on board the Humber. From the captain down, every man on the ship did his utmost for the comfort of the visitors, many of whom had only the clothes they stood in left. They feel very much the facilities and kindnesses rendered them in their time of need.

Upon reaching Taku the gravity of the position was first evident, so that another war vessel was at once sent to Peitaiho to bring away those left there, and, as we know here in Shanghai, these arrived safely in Taku on Saturday last. This leaves the entire railway service in the north in the hands of the Chinese, and the damage done can well be imagined.

Among those who came away from Peitaiho was a gentleman who was stationed at Shanhaikwan, and he says that all was quiet there until Sunday, the 17 th. There were about 25,000 troops there under the command of General Sung, and these were well in hand, that leader keeping them under an iron discipline. On the Sunday he wanted to send 4,000 men with sixteen field guns to Yangtsun, in obedience to orders from Peking, but this he found was impossible owing to a bridge being down near the place. He therefore ordered his men to march overland. He desired the foreigners working the railway there to remain, offering them an escort and guaranteeing their safety, but they thought it better to get away while they had the chance. So they too went down to Peitaiho and joined forces with the other foreigners there.

These gentlemen, upon being asked as to the number of Chinese foreign drilled troops about that district, were able to give some details. There were at least 25,000 well drilled and armed troops at Lutai under General Nieh, and these are the men who were supposed to have been ordered to put down the Boxers in the first instance. Outside of Tientsin, in a place known to the foreigners as Suchou, there were 15,000 equally well drilled troops under General Yuan. At Shanhaikwan there were 25,000 men under General Sung, and these are said to be under the most perfect discipline. As proof of this one of our informants states that less than a month ago he himself saw over thirty men beheaded for having broken orders. At the same time these men are said to have told Mr. Kinder personally that if the trouble reached them they would join the Boxers, as they believed they would come off victorious. In addition to these camps 
in the districts away from the capital, Generals Tung Fuhsiang and Jung Lu, who are in command of the forces about Peking, are said to have each 75,000 men, well armed and fairly well drilled, and these are the men upon whom the ruling party in the capital rely for the driving out of the foreigners.

As to the position of the force attempting to relieve Peking, under Admiral Seymour, the following statement was elicited. General Nieh, who was in command of 15,000 troops at Lutai, was ordered down to disperse the Boxers, and when he got as far as Lofa, the station next to langtsun, he found that one of the bridges ahead of him had been destroyed, and that he could go no further. He cletrained his men and marched overland finally meeting the Boxers, and after a short engagement retiring. While awaiting here for an opportunity to again renew his attack he received orders from the Viceroy to return to Lutai, and accordingly went back. In the meantime, the foreimn forces at Tientsin had decided upon the attempt to relieve the Ministers at Peking, and just after General Nieh had left they sent out up the line, attempting to repair the track as they went. This occupied them four days, by which time they had passed Yangtsun and nearly reached Lofa. Here they were caught like rats in a trap, the bridge at Yangtsun being burned, while a still larger bridge, known as Numher I3, ahead of them was likewise destroyed, so that they could neither go forward nor back. This left the force dependent upon its own resources for transportation and all the work. Up to this time they had been supplied with distilled water daily from Tongshan, but a provision train which was despatched just before the break in the line was wrecked, and the stores therein looted, so that in addition to being cut off from their water supply thay were without any large quantity of food. The only water that could possibly be procured was that from the river, close to which they would therefore be forced to keep, and cven this after being boiled and filtered was the very worst thing to drink. As for food, our informants think that this will indeed be scarce, as the inhabitants of this arid plain, few enough at all times, have for some time been flecing, while the horde of lawless horsemen and others who have been scouring the place for weeks past will have taken everything left long before the arrival of the force. The only good point to be drawn from the description of the place is that it will be comparatively casy to draw the small machine guns as long as there is no rain. But what the force has been able to do in the way of food and water is indeed a question.

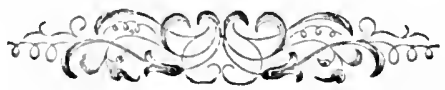




\section{THE DISTURBANCE IN EAST SHANTUNG.}

A representative of the "Mercury" had an interview in Shanghai with Dr. Faries, of the American Presbyterian Mission at Weihsien, which was burned by rioters, and learned some particulars as to the mission. Dr. Faries stated that there were nine American adults and seven children connected with the mission. He had had no news as to their safety, but he believed they would have left the mission before the disturbance, as the Consul at Chefoo had sent a steamer to collect the foreigners. Nevertheless, Dr. Faries had grave fears for the native Christians in the district. There were about eight or ten German miners some distance south of Weihsien, and there was an English Baptist Mission at Chingchoufu, about 45 miles west. When Dr. Faries left the mission everything was quiet, and no one anticipated any trouble.

They had been threatened in the spring when the trouble arose with the Germans, but since then there had been complete peace. The buiding of the railroad had brought a great many rough characters to the district. He had been informed some time before by friendly natives that a paper had been passed around among the roughs in a place about twenty miles away appointing a day to come and clear them out, but they did not put any weight on that.

There was a large force of soldiers who had been drilled by Europeans in the district, and they were on very friendly terms with the commander, whose rank was that of Major-General, and Dr. Faries had often attended him medically. Many of the men too came to the mission for medical attention.

Dr. Faries did not think the men who attacked the Mission were Boxers, although a leader of the party might have come from the west. In Chingchoufu, however, there were a great many of the lowest class, opium-smokers and thieves.

The roughs there had a leader who claimed to be descended from Confucius, and there was another who was said to be a hereditary Hanlin. The peasantry were very much opposed to the Boxers, and had on one occasion buried alive about 50 members of that society. Law suits were the cause of much difficulty between Christians and heathen, and the missionaries always discouraged their members entering into any.

Dr. Faries attributed the present troubles partly to the 
drought in Northern China, which had brought on a famine, partly to the natural irritation of the Chinese at seeing large portions of their territory occupied by foreigners, and largely to the reactionary influence of the Empress-Dowager.

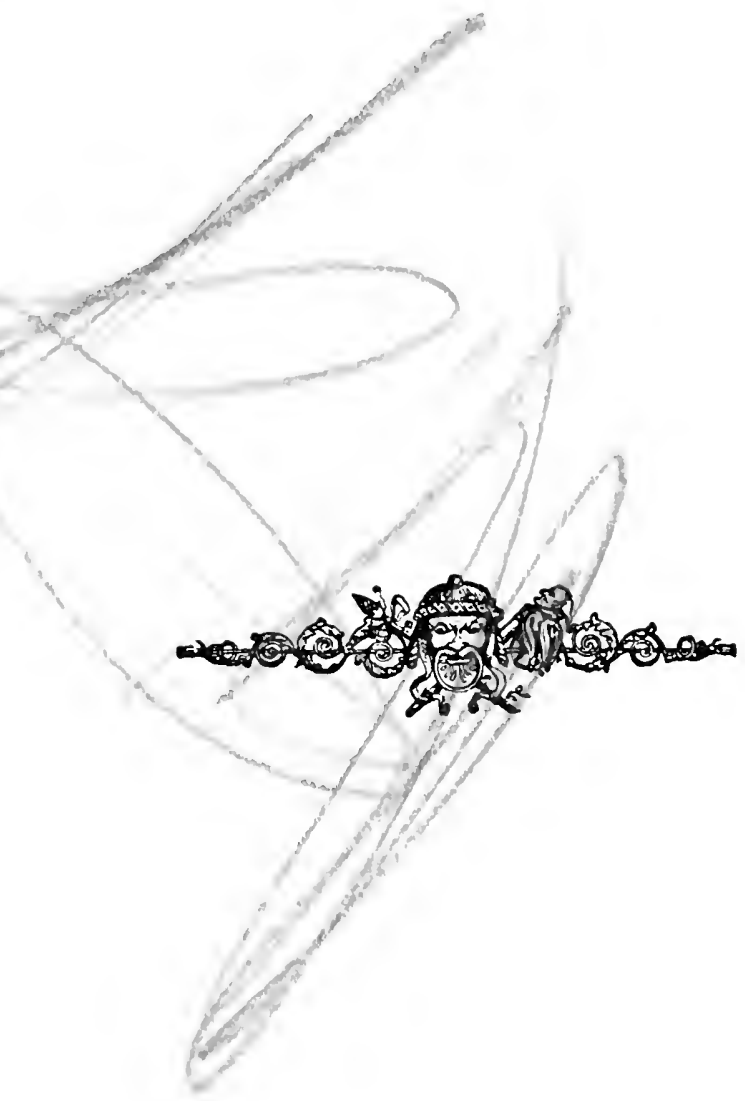




\section{THE SIEGE OF TIENTSIN.}

On Thursday, 5th July, I900, we had a quiet day after the first early hours of the morning, when on both sides there was some sharp cannonding.

On Wednesday afternoon the Chinese came from the city in considerable force and, even all through the heavy thunderstorm raging at the time, kept up a very persistent fire. They were repulsed and doubtless had good reason to repent of their temerity. Our authorities here, however, are badly off for information about the enemy. No foreigner can become a spy; detection would be immediate and vengeance terrible. On the other hand the Chinese supply is looked on with suspicion. It may be true or not.

On Friday morning also our guns were going at frequent intervals, and there seems some pretence at a reply from the vicinity of the city, but it is not from the big guns used during the first days of the bombardment. Apparently these, as reported, have really all been put out of action.

On Thursday a big lighter and tug was put at the service of those who wished to leave for Taku and the steamers there might take them to Shanghai or Japan. Most of the women and children left and others who had no duty to call them to remain. The whole company must have numbered more than a hundred. Also many of the British and Russian wounded were removed. Of the latter about 150 were taken away.

Among those whom we noted leaving were-Bishop and Mrs. Scott, Rev. and Mrs. Iliff, Misses Grimwade, Crettall and Smart, Mrs. Murray and four children, Miss Rickaby, Mr. and Mrs. Poulson and family, Mr. and Mrs. Southcott, Mr. Clifford, sen., and Mr. Clifford, jun., Mrs. Pyke and family, Dr. Smith, Mr. Michie, Mr. and Mrs. Hinds, Misses Shockley, Jones and Patterson, Dr. Stevenson, Mr. Cheesman, Mr. and Mr. Hancock and family, Mr. and Mrs. Forbes, Mr. and Mrs. Dickenson, Mr. and Mr. Way, and many others.

I I th July.-We hear of the refugees mentioned above having got off all right, after, however, very considerable inconvenience at Taku, where for one night at least almost two hundred had to find room on one small steamer which had accommodation for a dozen or so, and 
in the matter of food more had to go without than those who could be provided for. The warships, forsooth! asserted orders had been received to take no one on board except it were to save life! No wonder some of the ladies wished to return to Tientsin in spite of all the horrors of bombardment.

On the 8th, 9th, and Ioth the Chinese have given us some sharp times of shelling. Their marksmen did so well that general admiration would have been expressed if only they had been shelling somebody else. However, we have had an off-day to-day and time to look round and be astonished how little harm has been done. A few more holes in some houses, rooms wrecked and glass broken, and one house burnt in the American Board compound, and that seemed about all, and yet when it was on it seemed as if the air was full of death and destruction, and so indeed it was. Many wonderful escapes are related. One old preacher of the American Board, who with his family had occupied a room for some weeks, was persuaded to change his quarters. Halfan-hour after, a shell came bursting into that very room and some hundred fragments, each enough to kill, were picked up there! A mother with her children decided to leave the nursery for a while; they had just gone below when the room was wrecked. These hideous things come with such a combined infernal whistle, roar and howl that comparatively few people stand out in the open to watch them, especially if the final bang is within easy distance of being struck. I heard of one house which had eighteen shells through it yesterday alone, so imagination can perhaps be left to picture the nervous strain of those who, however little they and their dwellings may suffer, cannot but remember that the next shell may strike them.

An attempt was made early yesterday morning by the Chinese in large force to cut our communications again. They were discovered working round by the West Arsenal and got as far as the racecourse. The Japanese, British, and Germans, however, were soon in the open against them. By some clever manœuvring they were completely at the mercy of our men and were soon in full flight, having lost six guns and about 400 killed. The Japanese did splendidly, and with their cavalry and field-guns cut off not a few. TVe had one marine and one bluejacket killed, and one officer and a few men wounded.

In the evening some hundred and fifty Boxers, armed merely with their usual swords, quietly crept right within the French lines and into the French concession! After about two hours dodging the bullets fired at them, they are said to have got away without the loss of a single man. The French are reported to have lost three men from the covering fire of Imperial troops across the other side of the river, and the French wounded have to-day been removed into the British Concession for greater security.

It has been a great treat to get papers up to the Glorious Fourth. It is good to hear that everybody seems better off than ourselves, that so many friends are safe for whom during our isolation we had feared the worst. May they likewise be comforted for us, 
and may we all live to see the New China for which so many in so many ways have worked and bled.

July I 7 th.-The storm seems over. For three days we have no shelling nor bullets flying around, for Tientsin native city and most of the surrounding forts were taken on the night of the $13^{\text {th }}$ and the

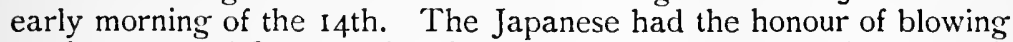
up the gate and first entering the city. The British were close behind. The city and outskirts was given up to loot and many civilians as well as the military and bluejackets of all nations were indulging to their hearts' content all day on Saturday. After then the British were prohibited from looting but the troops of other nations seem far from giving over. Gold and silver were what was chiefly in demand and from the Salt Commissioner's Yamen alone some millions of taels have been taken. The British are having it brought to one common centre to be afterwards equally distributed as prize money.

Japanese, American, British and French hold different portions of the city. That portion round the East Gate held by the Japanese, both inside and out, seem to have suffered by the bombardment and fire hardly at all. But from the South Gate to the North it is a continual ruin. On either side we walked by charred and smoking houses, and corpses lying still undisturbed. The same is also true of a great part of the northern suburb, once the busiest and most prosperous of all the mercantile part of native trade. The contrast is saddening.

Nemesis has overtaken the proud city. Its people and rulers did nothing to stem the rising tide of Boxerdom. In many cases those enemies of God and civilisation were welcomed. It was generally hoped that they would win. These "Heavenly Soldiers" were believed by almost all to be invincible by the power of their idols, and consequently even educated Chinese, many of them in the employment of foreigners before the trouble became acute, generally thought it safer to throw in their lot with our foes. They have had, many of them, a rude awakening, though it most also be confessed that those who remained have been treated as if they were all Boxers or spies, and have been freely looted, their houses burned, and themselves driven out to any fate that might await them. Snipers in their midst were, however, largely responsible for this.

The Russians have again been fighting nobly after their days of inaction. To them was given the position outside the eastern and northern suburbs. It was they who met and vanquished the main body of Imperial troops. They took the forts and re-captured the arsenal which, when Admiral Seymour came down from Peking, he had to abandon and which proved to be very far from being destroyed, 300 guns being now in Russian possession from there.

The praise of the Japanese is on every lip, and they suffered terribly from the galling fire of the Chinese in the attack on the city. In proportion to their numbers the U.S.A. troops seem to have suffered most, for out of about 900 men engaged on that day their casualities amounted to over a hundred, among them brave Colonel Liscombe, who had only arrived from Manila the day before. Their 
hospital, packed upstairs and down, was a terrible sight on the morning of the next day, and it was whispered that "some one had blundered."

The British, like most of the attacking force, only some fifty yards from the enemy, had to lie all day in the trenches, so fierce and persistent was the fire from the wall. The wounded, some of whom were hit early in the morning, had to lie till clark in some cases unattended to, though Dr. Hall right in the firing line did his best by all of them. To add to their misery many of the urenches had been flooded by the Chinese.

The French, though they appear to be enervated by fever from the swamps of Tongking, also suffered heavily but contributed their full share to the honours of the day. That the Germans and Austrians did likewise it is unnecessary to write. It was truly a victory of the Allied forces.

There is abundant proof from testimony of natives and discarded uniforms that the troops of the Salt Commissioner were chiefly, to the number of a thousand, the defenders inside the city. That they made such a good defence was due to the splendid cover at their command. After the gate was blown up they, however, fled panic-stricken, and there practically was no resistance to the entrance of the rush of troops. At first everyone was shot indiscrimately, but afterwards only those who had arms. As these were readily discarded together with uniforms and Boxer emblems it is probable that the thousands of Chinese who at the tail of the foreign troops have been these days so busily looting on their own account contain not a few beforetime Boxers and troops.

The natives say that on the last days the troops and people turned on the Boxers and slew some hundreds, with their leader, as responsible for all the trouble come upon them and threatening them. Many Boxer placards and proclamations on yellow paper are yet prominent. These stuck on so many houses seem ludicrous now, when not victory but utter clefeat has overtaken them. On one occasion, however, the Hsien by proclamation announced a great victory and 100 taels for each man who had been engaged. I hope our men will do as well.

It is amusing to see how the natives in the city almost all go about with little flags, most of which bear a legend and the national emblem of the Japanese; some few have pieces of paper on which is written lirance or England, but the many have professedly become "Submissive subjects of Japan." I noticed on one house that the legend had been translated by some ambitious scholar into "Large Japan "written in Roman characters. The Japanese, too, have issued proclamations in Chinese characters stating the part of the city and outskirts they are responsible for, and announcing that if there be cause for complaint application could be made to their officers. None of the other powers seem to have thought of such a thing yet, things being allowed entirely to drift.

The crowds in the city seemed to by no means bear malice to the 
foreigners. I suppose they are thankful their lives have been spared and that they have had so good an opportunity of looting their neighbours. One missionary has already had not a few applications for admission to the church "this very day if possible!"

July 19th.- The natve city presents an awful sight. Silver (sycee) thrown down by fugitives in their haste to quit the doomed place is being picked up all round, and terror struck natives who remain on the scene never show themselves out of doors without little flags to show that they "belong foreign side." Poor fellows, they have seen so much bloodshed that it is little wonder they try many expedients to keep the dreaded Russians from riddling their bodies.

All the junks found on the river are to be used for the conveyance of troops towards Peking, and everything goes to show that a speedy advance will be made.

By this time the magnitude of the reverse suffered by the Chinese at Tientsin may have dawned on the arrogant Prince Tuan, whose days of power are near an end.

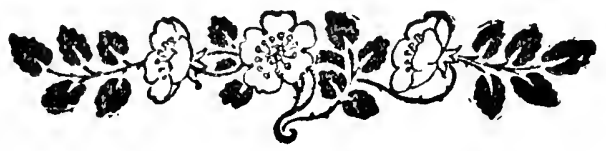




\section{ESCAPE OF THE SHANTUNG MISSIONARIES.}

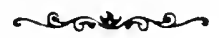

By the courtesy of Hon. John Fowler the Chefoo correspondent of the "Shanghai Mercury" was able on 19th July to send an account of the hardships to which some of the Shantung refugees from the interior of the province were subjected. It seems almost miraculous that the scores of missionaries in that province have escaped without loss of life to places of safety. For this happy consummation very large credit attaches to $\mathrm{Mr}$. Fowler, the American Consul at Chefoo, who rendered inestimable scrvices to his nationals as well as to the English, Italian, and French residents in the interior by promptly securing a steamer to bring the foreigners to Chefoo. The friendly attitude of Governor Yuan was of course a prime factor in the safe withdrawal of so many.

The appended account alludes to the first two of the relief expeditions which the steamer chartered by Mr. Fowler made. Two later trips, which were without serious incident, completed the work. So far as known but one foreigner now remains in the interior of the province, a French priest who was in Pohsinghsien, near Chingchowfu. It will be possible for him to find his way to Chefoo by junk. The parties subjected to the hard experience related by Mr. Cornwell were, among others, Dr. and Mrs. Crawford, both of them of advanced age, Mr. and Mrs. Bostick and five children, Mr. and Mrs. Partch and two children. Also the members of the Methodist Mission in Laoling and the members of the Anglican and Gospel Missions in Taichafu.

Report of Rev. Geo. Cornwell, who went to Yangkiakow, an inlet on the coast of $N$. Shantung, over 206 miles due west of Chefoo, with the Janpnese ship Kiwanko, chartered by John Fowler, Esq., U.S. Consul, Chefoo, for the purpose of rescuing endangered American and English Missionaries from the interior of Shantung and Honan:-

$$
\begin{gathered}
\text { Japanese ship Kwanko Maru, } \\
\text { 29th June, } 1900 .
\end{gathered}
$$

John Fowler, Esq., U.S. Consul.

Sir,-Herewith I submit to you my report of the undertaking with which you honoured me in sending me in charge of the Japanese 
steamship Kwanko Maru to rescue the Missionaries who should gather at Yangkiakow.

Leaving Chefoo at 3 p.m. on the 20 th instant we reached Yankgrakow Roadstead at IO a.m. on the 2 Ist and arrived at the dock, some 40 li away ( 13 miles) at 2 p.m. I found only one person on hand, the Rev. Cosaire, a French Bishop. That evening the French Consul and wife arrived, bringing word that the Chinanfu party would not arrive before the $25 \mathrm{th}$, consequently I made a proposition to the Consul to take the steamer and return to Chefoo at once, paying all the expenses of this trip. He gladly accepted the proposition. On arriving on the afternoon of the 2 Ist I had at once sent a special messenger to Weihsien with warning and promise to wait until the $23 \mathrm{rd}$. On the $23 \mathrm{rd} \mathrm{I}$ sent another messenger to Weihsien and one to Chouping and Chingchowfu promising to wait for the people or for return letters. On the $24^{\text {th }}$ Mr. Nickalls (Eng. Bapt. Miss.) and a party of 4 adults and 2 children, and about noon Mr. Fitch of Weihsien (Amer. Pres. Miss.) arrived overland with a large party of ladies and children ( 10 in all). At my request the French Consul had left his guard of 30 Chinese soldiers for me and they were efficient and obliging.

During the two days before the people began to arrive I explored the town and made arrangements at the best hong (native firm) for sheltering them, and laid in supplies. Realizing that egrs would be scarce in Chefoo, I undertook to buy up all on the marliet, both for use on the boat and for the refugees afterwards at Chefoo.

Several thousand were secured. On the morning of the 25 th I sent the two above-mentioned parties down to the steamer and watched for the Chinanfu party in order to transfer from the river boat without going to the inn. The Honan party (Canadian Pres. Miss.) of ten persons, consisting of 5 adults and 5 children, were thus transferred when they arrived at $\$$ a.m. and sent aboard the steamer. A large Chinanfu party arrived in twelve boats at 9 a.m. of the 25 th. Difficulty was found in securing lighters. The third lighter which I had previously secured was filled and sent down the river to be driven back shortly after starting by head winds. Failing in securing lighters I applied to the Customs, who obtained for the rest of the party a large junk. All went aboard at once and tried to drop down the river to the ship. Wind and tide were contrary and we could not start till after midnight. We kept to the boats, eating and sleeping as best we could aboard, and at the turn of the tide were able to make about io li ( 5 miles) before daylight against head winds. We tacked against the wind all day and late in the afternoon reached the coast, still some 20 li ( 7 miles) from the steamer. The wind became high and clouds threatening, so we were forced to lie-to another night. The rain fell heavily and I feared a typhoon, so we had all the foreigners get aboard the junk lest the lighter should be sunk in the night. When the rain ceased five people returned to the lighter, and the wind increasing, to prevent the bumping of the boats against each other we cast off the lighter and it anchored near by. In the 
morning we determind to make an effort to reach the ship which we could just descry, for the Japanese interpreter, Mr. WVato, had come aboard the evening of the 26 th and informed us that the water was low so that the ship would have to return to Chefoo if we could not embark the morning of the 27 th. WV worked out on the last of the eb! tide and were forced to the N.VV. of the ship by the strong wind. Nearly all became seasick. Reaching a depth where the steamer could come we anchored and sent up a flag of distress, also firing several volleys with the guns of our native escort. Most of these were too sick to hold a gun and three of us foreigners assisted. The lighter headman, while he followed us out did not dare to anchor. In peril of swamping, the crew tried to put the passengers aboard our junk, but we did not dare let them attempt it. The soldiers and sailors were much scared and put back, slowly sailing out of sight. After two hours of waiting and tossing about, we managed to attract the attention of the steamer. She cautiously drew near and signalled to us to draw alongside. This we could not do, for the tide had turned and we dared not lift our anchor, lest we should be drifted entirely out of sight. Then two sailors from the ship dropped down and swam through the heavy sea to us, bringing ropes, and were pulled aboard exhausted. Hawsers were attached and the steamer drew us up within talking distance. During this process in attempting to raise our anchor the bowsprit broke off and we had to let the anchor and rope go into the sea. The sailors were so reluctant to do this and the delay increased our peril, that Mr. IVato drew his sword and seized the dagger of one of the guard to cut the rope. The sailors thought we were about to attack them and pleaded for their lives, and at once proceeded to cast off the anchor. Then as Mr. IVato, while interpreting, stood astride the hawsers a lurch wrenched them from the guide pins and knocked him flying into the sea. He grasped the sagging rope with great presence of mind and pulted himself up to the ship, where we hauled him over. In another moment the trawl broke loose from behind and went adrift with the anchor and, being in tow by the steamer and a heavy wind being on, we had to let it go. The steamer now attempted to tow us to a place of safety, but the boat pitched so and the waves dashed over us, so wo had to be dropped. The Captain had arranged with Mr. Wato to go and wait in the harbour, 40 miles off, and wait for a calmer sea, but I had Mr. Fitch tell him to go at once back to Chefoo and send a ship for us with a steam tug. The ship went on and we came flying back in one and a half hours. I immediately sent a telegram to go ria Veihsien informing you of our difficulty and asking for a ship and launch and announcing our safe return to Yangkiakou. TVe had found the lighter on our way half way back and it accompanied us back. I immediately rushed to the inn hong to make preparations for our party and was met by the alarming news of the burning of the IVeihsien compound. IVe were denied admittance to the inn, courteously but none the less firmly, and I had to get the Customs official to use pressure. Then the whole inn was practically put at 
our disposal. We called in the guards and arranged for so of us to sleep on the premises. I gave orders that the ladies and children were not to go out, nor the men who were not soldiers to be out much on the street. I spent money freely on all sides and had to pay roundly for the damages to the junk. TVe organized a community and soon were quite settled and comfortable. Rumours about IVeihsien grew more certain and reports of Boxers on the streets began to come in. We called on the Customs official and urged him to forbid all gathering of men on the streets, and to hold the hongs (native firms) responsible for the good behaviour of employés and guests. We impressed upon him the fact that nothing was to be gained by a disturbance and told him forcibly if so much as a child was injured there, the place would be razed to the ground. We sent messengers again to Chouping and Chingchowfu (Eng. Bap. Miss.), informing them of rumours and urging them to join us at once. On the 28th at noon Mr. Couling came in from Chingchowfu with a party of eight adults. At dark Japanese sailors appeared from our boat reporting that the boat had gone and got water in Laichowfu Bay (40 miles east) and there had seen the steamer Heian from Chefoo and heard alarming news of the state of affairs in Chefoo. The country people also proved very hostile. At the same time word came in from various sources that the Boxers were gathering in town and 100 had been seen. TVe had already transhipped our heavy baggage and loaded it with that of Mr. Couling on three lighter's. We decided to go off that night.

Began loading at 9 p.m. and finished, with accounts settled and arrangements made for those who should come after, at 2 a.m. Then we immediately started down stream with a light breeze and reached the ship all safe, the last boat about 8 a.m. I had planned to stay and help the remaining parties through, but became alarmed by the accounts of the state of alarm in Chefoo, so came back prepared to return if Heian desired on the next ship. We had heard that the Japanese ship would go to Yangkiakou on Saturday so I left a letter for the Captain, prepared by Mr. IVato, requesting him to wait for the remaining refugees and promising to pay him $300 \mathrm{Mex}$. a day from the time his cargo was discharged. We had arranged for our guard of 40 soldiers to wait two days for the next party, and had paid their expenses for these two days. I also left letters with the guard for the party. Then we came on toward Chefoo, turning aside to Taipingwan in search of the Heian. We found her there at anchor, and $\mathrm{Mr}$. Nichols, the interpreter and I went aboard. The Captain and his officers were very pleasant and ready to do anything they could, but the compradore kept us parleying a long time and finally refused: (I) to wait for the people at Yangkiakou, and (2) to take them aboard if they came out while he was unloading, and (3) even to take on board any one to meet them. He was obstinate in his refusal; then we offered 300 dollars a day, even beginning from where the ship stood and a cumshaw besides and the Captain urged him to be allowed to do so. Then we put before him the serious nature of his refusal, as it was 
possibly a matter of life and death, but it was of on use. Then we threatened him with dismissal from Kaiping $\mathrm{Co}$. and summary treatment by American and Japanese Consuls, if he persisted in his refusal. He practically ordered us to leave the ship, and we did so leaving him and his crowd of evil-looking Chinese passengers. I never saw a worse lot of fearsome evil afoot. The Captain said he could not act contrary to the compradore's orders ordinarily, even so as to take one of our party back with him, but he declared that if any refugees came out to him at Yangkiakou he would take them aboard and protect them with no regard to what the compradore would say. Immediately on our leaving the ship she started for Yangkiakou. Mr. Wato was as indignant as any of us and will represent the matter to his Consul. I told him I should ask you to request a Japanese war vessel to go at once and seize the compradore and prevent any mischief he may be devising. I also enclose list of passengers, notes of resolutions passed by them, and list of people still to be rescued.

Respectfully,

Your obedient servant,

Geo. Corswel.l,

Amer. Pres. Miss. Chefoo. 


\section{NEWS FROM CHEFOO.}

2oth July.-Governor Yuan has given the Consuls here to understand that he has only two methods for the protection of native Christians and Missionary property in the interior.

The Christians must recant, for a time only', and the property must all be, pro tcm., confiscated. It remains to be seen what the effect of his endeavour to coax the Christians into recanting will be. It is to be feared it will mean the taking of many lives. Yuan does not seem to have any more power than a hsien magistrate in some matters, for his underlings pay little attention to his proclamations.

A few days ago a steamer landed a Boxer, who had been smuggled on board at Taku. He was badly wounded, and died upon discovery at this port. After his death the red sash and emblems of the I-ho-chuan brotherhood were found on his person. Up to the present none of the fraternity have started a crusade against foreigners in Chefoo.

The writer saw a Chinese gentleman minus queue and ordinary flowing robes. He was dressed in foreign clothing, and did not look at all out of place in them. Quite a number of Cantonese, it is said, contemplate following in his footsteps ere going to Tientsin. The idea has got abroad that the Russians will shoot any Chinaman dressed in native garments they come across.

Yuan Shih-kai has wired to the British Consul that all at the Legations in Peking were well up to the 15 th July.

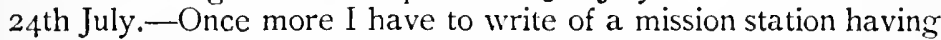
been looted. Ching-chou-fu, in the west of this province, the headquarters of the English Baptist Mission, in which work has been carried on successfully for many years, has been stirred up to loot their homes, hospital and museum through the hostile proclamations of the "Hsien" official, who practically gave the people a free hand. It is said the Franciscan property has been dealt with in a similar manner.

Some three thousand soldiers and horses arrived at Port Arthur on the 2 Ist on board the s.s. Manchuria, en route for Taku. The Russians are sending troops on to Kirin, some coming from Vladivostock and others from stations north of Manchuria.

"The Brave Boxers," who are playing such havoc among native Christians west of Chefoo, do not seen to have heard of the fate of 
their Tientsin brethren, and are inclulging in talk as big as ever. The Taotai here is to be killed first by them. then the foreigners, and lastly native Christians and the servants of foreigners.

Yuan Shih-kai still continues to send excellent proclamations to the Consuls at this port, but action on his part seems almost nil. $\mathrm{He}$ protected the forcigners journeying to the coast, and for that deserves all credit, but he has accomplished little towards bringing matters to a satisfactory conclusion.

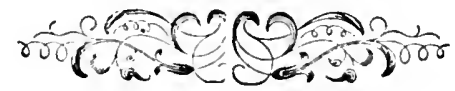




\section{AFFAIRS IN WENCHOW.}

The Shanghai Mercury correspondent, writing on July 23rd, says:-The s.s. Poochi arrived here on Saturday afternoon last (2 Ist), bringin back the Customs staff, one member of the Methodist Mission, and a priest of the Catholic Mission. There were besides on board as passengers, a new Prefect and a new Chentai for this district, sent to replace the two officials who, by their apathy, if not actual encouragement, lent support to the recent disorderly and riotous scenes enacted in this neighbourhood. The Poochi, although ready to leave Shanghai on Thursday, the Igth, was specially detained till 5 a.m. of the day following, awaiting the person of the new Prefect, who arrived from Hangchow at 2 a.m. and forthwith had an interview with Sheng Taotai before proceeding on board.

The Governor seems very determined to suppress the present movement, as indicated by the prompt measures he has taken to remove the offending officials; and report has it that it will go hard with these latter. He is also credited with having written a strong despatch to the Taotai. The Taotai, as mentioned on a former occasion, is weak, though willing, and was besides much hampered by the arbitrary attitude taken up by the Acting Chentai, now removed, but he has in the meanwhile been strengthened by the arrival of 500 soldiers from Ningpo by the Chao-wu, on whom he is able to rely to support him.

In Wenchow city nothing of moment has transpired during the past week, though the precaution was taken to close the city gates early, and to open them late, to prevent the influx of the rowdy element from elsewhere. The houses of the foreign community have remained unmolested during their owners' absence, and not a single instance is recorded of an attempt having been made to break into them, nor has a loss of any kind been experienced. Everything was found as left, which cannot but be considered as eminently satisfactory. The report current on the eve of the Poochi's last departure that 3 ,000 Boxers were marching on the city has been entirely disproved, and was evidently the vapourings of the versatile brain of some alarmist. Boxers in the true sense of the word, and affiliated with those bearing the same nomenclature in the North, do not exist here. The term, so far as Wenchow is concerned, seems to have been 
applied indiscriminately to all local sccret societies who, availing themselves of the opportunities offered by the present troublous times, are entirely responsible for the havoc and wrecking of lives and property in the neighbouring districts of Jui-an and Ping-yang.

One learns on fairly reliable authorty that three native Christians have lost their lives in the above-mentioned places; one was done to death, one was driven into the water and drowned, and one, on his house being surrounded and seeing no means of escape, committed suicicle in despair by hanging. The house of Mir. Grierson, of the China Inland Mission at Ping-yang, is said to have been utterly wrecked.

The Taotai has made some important arrests, amongst them two men who were recognised as having been ringleaders in the rice riots of two years ago, and these are now under sentence of death, which, it is given out, will shortly be carried into effect.

To mark his pleasure at the return of the Customs staff the Taotai called on the Commissioner of Customs yesterday, the Emperor's birthday, an unusual thing to do, considering the day, and was followed by the new Prefect somewhat later.

The offieials evidently being in earnest, everything points to a happy issue out of the present difficulty, and an additional sense of security will be felt when the Customs cruiser Chuentiao, now due, which has been detached as guard-boat for this port, arrives from the South.

The Futa'i's proclamation enjoining the protection of foreigners and their interests are being literally scattered broarleast throughout the country, but the same document also proclaims the intention of preventing foreign men-of-war from entering any of the ports of this province.

The Poochi, leaving to-morrow, will take away Dr. Hogg of the Methodist Mission, so that besides the Customs staff the only foreigner left here will be the Rev. C. Louat, of the Catholic Mission.

2nd August.-On the arrival back of the Customs Staff by the revenue cruiser Kaipan on the 5 th ult. everything was found to be quiet in the city, and the day itself, which was the one originally set apart for the extermination of the foreigner, passed off peaceably, without any attempts being made to put the project into execution. It may be that the presence of the Kaipan acted as a deterrent, or, what is perhaps more likely, the departure of the notorious prefect Ch'i Hsu, who was en route to Ningpo by one of the government launches just as the Kaipan was coming up the river. The prompt way in which the Governor dismissed this obnoxious official on hearing of his anti-foreign propensilies has doubtlessly had an excellent moral effect.

The Kaipan was the object of much curiosity and speeulation on the part of the people, and being anchored within a very short distance of the shore, and exactly opposite the Custom House, large crowds thronged every day on the bund to watch them go through their gundrill on board, and the sight of this has no doubt acted as a salutary check on the more turbulent section of the populace.

The revenue cruiser Chuentiao arrived here on Monday, relieving 
the Kaipan, which left for your port on Tuesday. On Monday the Poochi also arrived, and brought as passengers three gentlemen belonging to the Inland Mission and one to the Methodist Mission, who came to see how matters stood. All of them will, however, be leaving again this morning by the Poochi. One of them, whose original intention was to remain behind, has been wisely persuaded to go also, as his presence here, apart from danger to himself, would only be a standing menace to the Foreign staff of the Customs in view of the intense anti-missionary feeling existing in these parts at present.

The local officials as now constituted are well disposed, and are using their best efforts to second the Governor's intention to maintain the peace. On the surface everything seems quiet enough in the city as this is being penned, but with such a large influx of strangers within the walls as there has been latterly, it would be sheer perversity to ignore the fact that the faintest spark would suffice to start a blaze. Reports of risings in the country-side round about reach us almost daily, and the latest news is that the city of Choü-chou on the Fuhkien frontier has been taken by the rebels (?) and the Magistrate there beheaded by them. 


\section{NATIVE ACCOUNT OF THE SITUATION.}

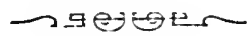

The following account of what transpired at Peling after the cutting of communications was specially translated for the "Shangriai Mercury" from the "Universal Gazette" of Ist August :-

The Peking Foreign Office has telegraphed to Shanghai by way of Shantung to say that the Jegations in Peking are tranquil. On the 22 nd of July the Foreign Orfice sent to Sir Claude Macrlonald the telegram received from Shanghai. When he replies the Foreign Office will forward a telegram stating his reply. The telegram from Shanghai was sent by Consul-General Warren.

On the loss of 'Tientsin through its capture by the foreign forces, the Viceroy Y'u Lu went with his troops to Peitsang. The troops are there, but he has gone in haste to Hokienfu.

The Boxers are very numerous in Shantung. If within two months the Tientsin and Peking Boxers are not repressed, it may be expected that they will give trouble in Shantung.

On June I6th on account of the urgency of the occasion it was proposed to send President Chao, who was Governor of Kiangsu before the appointment of Kweichun, and the Peling Prefect Ho, to enter into a friendly conference with the Boxers. But Grand Secretary Kang in a memorial to the Empress-Dowarger said that if Chao went an open rupture with the Boxers would be the result. He asked to be sent himself. The Empress consented and he reached Chochow on the 7 th of June. The other two envoys were there before him. Chao regarded them as rebels and thought General Nieh should be commissioned to put them down by force. With this view Prefect Ho augreed. Grand Secretary Kanğ has always disliked General Nich and strongly maintained that he is in secret communication with foreigners. Me ought not therefore to be entrusted with this duty. To this opinion Prefect Ho gave his approval. Governor Chao on hearing this smiled, and said, "If it is so then I will, if you approve, return to Peking." Ile went back accordingly. On June gth General Tung's brigale cntered Pcking. They had previously been in the Soutin I'ark baracks. The city was not well guarded and Prince Yuan, with Grand Secretary Kang, asked the Empress-Dowager to rirect Genceral 'lung to bring his brigarle into the city. On may 3 Ist fienerat Iun had an audience. Emboldened by this favour the fansu brigate, when the first division of them came into Peling, the 
officers and men holding the imperial order in their hands, publicly said, "We have the Empress's orders to slay all foreigners. Her Majesty ordered the Boxers to come as the first division of the army. We have come to aid them." All who heard this were greatly alarmed.

On June Ioth the Boxers were busy in their work of slaughter. The Kansu brigade had with them in Peking General Yau, general for Kansu and a native of Anhwei. He had come to maintain order among the troops. He saw in the streets very many men with red sashes and caps. They shouted, "TVe are going the kill the devils." General Yau rebuked them. "In this time of peace why are you so far wrong as to use such words? You will kill the demons, will you? You should bear in mind that the demons may kill you." "The robbers shouted, "The two hairy men are come." The two hairy men in their slang are the Christians and those who praise foreigners. The origin of these expressions is found in mantsz "Hairy one," the Tientsin word for foreigners. General Yau said with strong asseveration, "It is not so." The rebels would not hear him. They took his horses and made him dismount. They then burned incense and a slip of paper containing a written request to know from the oracle if he was a Mantsz or not. If any one denied that he was a Mantsz they test his statement in this way. If the incense did not burn out nor the paper on which the request was written, then the person is a Mantsz. He must be killed without mercy. Just as the robbers were about to kill General Yau, a military officer in a Peking encampment named Li came quickly up on his horse and urged them to desist. "Wait," he said, "for your leader to come before you kill him." After some time he came. He looked at the oracle, and said, "This man must be killed. Let there be no more words about it." Li said, "Just now you promised me not to kill him. Why have you broken your promise?" Hearing this the robbers wished to kill him too. $\mathrm{He}$ spurred his horse and escaped. He was carrying 200 ounces of silver and two gold bracelets. They fell and the robbers secured them. One officer of the camp embraced the body of the slain man, loudly weeping. He also was lilled.

June I Ith.-On this day the general body of General Tung's troops that had remained in the South Park entered the Yungting-men. This is the central gate of the Chinese city on the South. They met a secretary, Sugiyama, of the Japanese Legation, who was leaving Peling in order to meet the foreign troops coming to Peking. General Tung's troops asked him who he was. He replied he was an official sectretary of the Japanese Legation. The soldiers objected to this, if you are an official secretary why do you use a cart with a red band round it. They seized his ear and made him come off the cart. The secretary knew that it was not a time to reason the matter. He said in a conciliatory tone, "Kindly allow me to see your commander, to him I will apologize." The soldiers said, "There is no need." "Then," said he, "I will later on invite your commander to my Legation and my Minister will apologize." The officers with their 
swords then killed him by cutting open his abdomen. The Japanese Minister on hearing it asked permission to have the body taken back to the city for burial. After a long time permission was given. Prince Tuan afterwards on seeing General Tung put out his thumb and said, "You are indeed a hero."

The Boxers are at Kaichow, a few miles south-east of Newchwang foreign concession. In this city the Boxers number about three hundred. They practise boxing and club exercise day and night under the direction of Mr. Yang, who is their captain. He says in his written title that he had come down into the world to uphold the Manchu dynasty and exterminate the foreigners. This rebel captain sent out twelve of his men to a retired valley among mountains about 20 English miles east of the city where there were some native Christians, two hundred in number, who had gone from the city to that spot for safety. All of them, including women and children, old and young, were to be murdered. There the bodies of the two hundred Christian lie exposed in that mountain valley. Alas! for them.

Two days ago the same rebel captain said to the messengers in the magistrate's office at Kaichow, "South of this city there is a well in a certain village which has been poisoned by some one. If you go quickly in a westerly direction you will be able to catch the men who have done this." Messengers were sent and on finding three men they inquired if they were instructed by foreigners to do this. They said they had been. The messengers then told the people of the village that they should clean out the well. The three guilty men were taken to the Magistrate. The Magistrate was about to investigate the case when the rebel Captain Yang prevented him, saying, "These men have been instructed by foreigners who wish to poison our people to appease their anger at us. These men ought all to be put to death." One of the three named sureties and was released on bail. The other two were beheaded on the steps of the Magistrate's office. The Magistrate did nothing more in the matter.

In Chuchow in the south-west of Chekiang, as we learn from a Shaoshing letter, rebel soldiers have, before the arrival of the soldiers sent by the Governor, killed the magistrate of Sian city named Mu. The murderers are merely enlisted volunteers. They pulled the Magistrate out of his sedan chair and then strucls him till he died His second and fourth son who came to rescue him they also lilled. "The same newly enlisted soldiers also set fire to the Christian Churches in the city, Catholic and Protestant. But they did not attack the Taotai's office nor that of the military officer nor that of the police. Several missionarics there have been killed; one ran for his life but was pursued to the front of the 'laotai's office and there murdered. The Chekiang Governor has sent 2,000 soldiers to Chu-chow. They would arrive too late to prevent these deeds of blood.

A foreigner in Shanghai has telegraphed to the Governor of Shansi offering $f_{5,000}$ reward for the safe escort of Mr. Pigott, his wife, son and a friend from Taiyuenfu to Shanghai.

A party of thirty missionaries from Lanchow and Chinchow are 
on their way through Szechuen to Hankow. A telegram has been sent to Viceroy IVei asking him to order the magistrates of his viceroyalties to escort them safely throughout the regions ruled by them, and to send men to conduct them through Szechuen to Hankow. The refund of expenses is guaranteed.

The same foreigner has telegraphed to Viceroy Kwei asking him if the party of thirty missionaries pass through Szechuen to give orders to the magistrates in each locality to conduct them safely on their way to Hankow. All expenses will be refunded. A telegram has also been sent to Governor Yu of Shansi stating that he will be held personally responsible for the safety of more than sixty missionaries in his province.

Nanking Letter.-All missionaries have left Nanking. Lists of furniture in houses and churches have been entrusted to the Viceroy for reference in case of looting.

The Nanking letter also states that Mr. Taylor, Acting InspectorGeneral of Customs, came here two days ago and consulted with the Viceroy on the tariff. After a long interview he went to stay with the British Consul. Next day he left for IVuhu to investigate the state of Custom duties at the Foreign Custom House there and elsewhere. In fact, however, Mr. Taylor returned at once from Nanking to Shanghai.

On June 12 th the Boxers assembled at Peling in still greater numbers and set fire to the houses belonging to native Christians surrounding the Yeukiatsing, a well of very sweet water in the Chinese city. On the same day they burned the racecourse buildings outside the Changyi Gate on the south-west of Peling. The racecourse buildings were foreign owned.

June I $3^{\text {th. }}$-The Boxers made an attack on foreigners in Legation Street. Eight boxers were killed by rifle shots. 'They therefore burned the church inside the Hada-men. Fortunately the missionaries had already taken refuge in one of the Legations. The native Christians with their wives and children to the number of two or three hundred were barbarously put to death. The buildings of the northern Methodist University are all burned. The native Christians belonged to the North Methodist Mission. The same day the foreign buildings at Tengshikow were burned and the old residence of Sir Robert Hart, afterwards occupied by Principal Oliver, with the Gasometer, and buildings occupied by a large part of the Customs staff in the street Kowlanhutung. These buildings burned brilliantly all night till dawn.

On June I4th the church outside the Shunchimen was burned; also grain shops in the Tachalar street, which belonged to native Christians, were burned. The hubbub of voices all night never ceased. [Note.-The Tengshikow buillings included a large chapel, a printing office, girls' schools and several dwelling houses, all belonging to the American Board Mission. The chapel outside the Shunchimen is Methodist and belonged to the Northern Methodist Mission.]

June I5th.-In another attack made by the Boxers on the 
Legations ten were killed and very many wounded. They therefore retired outside of the Tartar city beyond the ' $T$ 'sienmen. At nightfall shops were closed and all was quiet. In the morning an edict came out with orders to put down the Boxers by force. A change had taken place in the policy of the Government. But the Boxers would not believe it and said it is not a true edict. To-night Grand Secretary Kang will return from Chochow and give in his report. He will firmly uphold the policy of fighting with the Foreigners.

June 16 th. - At 9 o'clock in the morning the Boxers set fire to Llewellyn's (Lautelii) establishment in the Tachalar Street. The fire spread to grain-shops on each side. Nore than four thousand shops and houses were burnt in this thickly occupied part of the Chinese city. Thirteen streets are a mass of ruins. The Gate tower of the 'T'sienmen was also burned. The Bosers would not allow the fire engines to come and check the conflagration. Next door to Llewellyn's the Kwangté firm used water to extinguish the fire. The Boxers said this year the gods are angry at water. This is the reason that the fire spreads. 'The people did not blame the Boxers for setting fire to the city. They blamed the Kwangté firm for checking the fire.

At one o'clock a Grand Council was called, of Princes, Dukes, and Peilê, the Six Boards, the Hanlins, and other metropolitan high officers. The Princes and Nobles with the Grand Secretaries Kang Yi and Yung Lu had a secret conference, and afterwards the Chinese high officers were admitted to see the Empress, who set before them the question for discussion-should there be war? The following Privy Councillors spoke strongly against war:-Wang Wenshao, an ex-Viceroy; Hu Kingcheng, a President of a Board: Yuench'ang and Tseng Kwanghan, that is Marqus Tseng, and Hu Kingt'ang; grandson of Hu Linyi, former Governor of Hupei; Hwei, an Assistant Secretary; Chu Tsumow and a Manchu, $\mathrm{Na}$ 'T'ung. The arguments they used were such as follow. Hu king cheng sail, "The ships of war of all the nations of the Tiest are gathering. War is not to be thought of." Kang Yi then said, "We have the Boxers. On them we can rely securely." I'uen Chang said, "I have gone in ordinary costume to Legation Street and saw Boxers lying dead with rifle shots. They die like other people. Many of them were lying there. They certainly cannot be invulnerable from riffe and cannon shot. The Boxers cannot be depended on for our defence."

The Empress said, "These are local thieves. They are not the true Poxers. If they were Boxers they woukd not be killed by cannon or rifle shot." Marquis Tseng said, "When we were at war with Japan we did not conquer. How can we expect to conquer when we are at war with all the nations against us? Further the interior of the capital ought not to be made the bittlefield." Assistant Secretary Hwei said, "Lien if we engage in war we ought to protect the Foreign Legations according to the requirements of International Law." Chu 'Tsumow said, "Let the Generals in command of troops in the adjoining provinces be called to Peking to give their opinion 
at another Council." IVang WVen Shao and Vice-President Suyung-i said, "It is indispenable to protect the Foreign Legations." Kang yi said, "Whatever be the decision it is at present absolutely necessary to prevent foreign troops from coming to Peking. Hu Kingcheng is conversant with foreign affairs; let him be sent to prevent the foreign army from advancing."

The Empress-Dowager commanded Hu Kingcheng and $\mathrm{Na}$ 'Tung to go together. It was then decided to fight.

June i 7 th.-The Boxers burned down the telegraph offices.

I Sth.-The German Minister was murdered (other accounts say June 20th). This was the act of the troops of Tung Fusiang and of the Imperial Guard, Wu Veichiün,

20th.-The Foreign Ministers sent a joint despatch to the Tsungli Yamen asking that the Emperor should resume Imperial functions and that Prince Tuan and Grand Secretary Kangyi should be punished for their crimes.

On the same day Grand Seeretary Yunglu gave orders to General 'Tung's army to fight. (Yunglu had hitherto been friendly to the foreigners. On June 23rd he openly joined the war party.) While the Council was discussing the question of making war the Emperor wept bitterly, and said if this is to be, then tens of thousands of my people will be subject to misery and desolation. Our Imperial Dynasty of 300 years' duration will come to an end.

The councillors earnestly debated the point. They were in two antagonistic parties. The Empress-Dowager could not have her way. The order to make war was then given.

On the same day General Tung's troops and the Imperial Guard were actively engaged in plunder and incendiarism. The houses of the Grand Secretaries Sun and Sii and of President Ch'ien, as also the palace of Prince Su, as well as the Hanlinyuen, the Board of Office and Board of Ceremonies were all burnt. President Ch'ien was escorted out of the city by foreign soldiers. (These would be the brave American Marines who hold the Peking wall at the back of the American Legation.)

June 24th.-Vice-President Chên Hiofen was on his way to the Temple of the Moon to inspect the sacrifices. He was met by Chinese soldiers at the Tunghwa gate (this is about seven minutes' walk north of the British Legation), who cut his throat. He died instantly. Thirteen members of his staff appointed to assist in the sacrifice were all either killed or wounded. On a day when I did not write in my diary I reached Tsangchow (about forty miles south of Tientsin) and saw the Boxers plundering the goods of passengers on boats; a hundred and five were killed. These Boxers belong to the body of rebels who were severely handled by General Mei, Military commander for Chihli province. He killed 3,000 of them. On July ioth I reached Hieuhien (a stage beyond Tsangchow and a district city near Hokien $\mathrm{fu}$ ). There the Roman Catholic Church is still intact. There are, I was told, 20,000 Catholics there in this city and its vicinity. To whatever places I came there were Boxers in great 
numbers, till I reached Techow in Shantung. Here there were none. 'The troops of General Tung do nothing but burn and kill. The cities through which they pass all suffer from their rapine and cruelty. In the cities of the interior fires are common and they are owing to the destructive activity of these troops.

On June 2 th and each following day the Peling officials came away in great numbers in carts and sedan chairs. Soldiers took away from them any cart they could meet with.

The Imperial Guard after they took to robbery were punished. A camp officer and ten soldiers were beheaded. But robbery still continued.

General Tung has lost a thousand of his men and the number of Boxers who have been killed passes calculation.

June 26th.- The Boxers have come to Shantung and have taken possession of a hill. Governor Yuan Shikai has attacked them there. Ha Picheng, a military officer belonging to Prince Tuan's army, has been killed by General Tung's troops.

A censor has memorialized the Empress-Dowager praying her to behead Prince Tuan. Grand Secretary Kangyi, and General Tung. The whole family of this censor have been put to death by the Boxers.

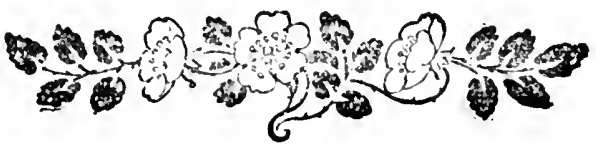




\section{THE SITUATION AT CHEFOO.}

The Chefoo correspondent of the "Shanghai Mercury," writing on 3 rd August, says:-As the days pass the bill that China will, somehow, have to settle, gets heavier and heavier. We hear that the Catholic missionaries, five in number, at Chiningchow, Shantung, have been murdered, and the mission property looted and destroyed. The Germans will have a good deal of rough work to do in striking terror to the hearts of the rowdy populace of S.W. Shantung. Let us hope that the weight of their wrath will fall on the heads of those officials who have secretly incited the people to shed blood, and to loot the property of foreigners. It would be well if such men were demanded of the Government and punishment be dealt out to them by the Germans, or some of the other Powers, so that the right men be punished and not coolies bribed to undergo their deserts for them.

The Boxers think Chefoo is not a favourable sphere for their operations. 'The few who were arrested by the Taotai, the other day, are safe in durance vile, and this has knocked all the "go" out of their friends, who have gone to seek for pastures new, in this neighbourhood.

On Saturday a story was current that the Boxers were going to make an attack on Chefoo on the evening of that day (weather permitting. This they carefully stated). About noon the boom of the Yorktown's guns and those of the Vladimir Monomach as they saluted probably had a calming effect on any excited Boxers that happened to be around, for not one of those braves showed face in the town or settlement. It may have been the heavy deluge of rain that damped their ardour, or Heaven's artillery as it echoed among the hills may have scared them, anyway, the day came and went peacefully as other days have done, and for all the Boxer brag we believe we will not be molested in this place.

News to hand from 'Tientsin to-day is encouraging. On the 3 oth the Japanese and Russians engaged the enemy about nine miles from Tientsin, and at first it seemed as if the day was going against them. One of the villages containing Imperial commissariat supplies was carried by assault, and cattle and supplies carried off. On the retirement of the Allied forces the Chinese returned and began to kill their own villagers accusing them of being traitors to their country and friends of their enemies the "Yang Kueitsi." The Russians, upon 
this, returned and surrounded the village, slaughtering a great number.

We likewise learn that Prince Tuan has cleared out of Peking with a large number of troops. Whether he is moving eastward to meet the advancing allies, or whether he is making good his escape none can tell.

Generals Sunc (a Shantung man, hailing, I understand, from Tengchow-fu) and Ma are it seems very determined to show a bold front, and to slay any waverers among their followers.

Boxers in great numbers are threatening to re-attack Tientsin, and it is desirable for the safety of the settlement that a sufficient garrison be left behind.

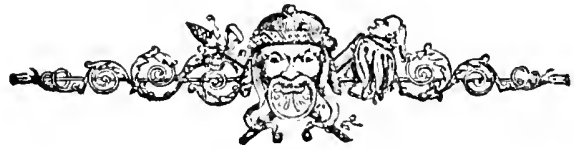




\section{THE MURDERS A'T KUCHAU,}

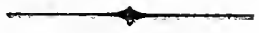

The following is a translation of a letter received from $\mathrm{Li}$ Minghee, Lank'i, dated 7 th moon, 7 th day, namely, Aug. Ist, I900:"With reference to Kuchau I gather the following report:-On the 25 th of the 6th moon, July 2 Ist, three men found in possession of three barrels of gunpowder were seized by the people (what people I don't know), and taken off with the powder to the local Magistrate's. They were at once put in ward. But at night these three prisoners were in the Hwating (Guest's Hall), feasting with the Hsien, whereupon the Pahsing at once concluded they must to Kolaohwei men, so they rushed into the hall, and slew all present, including the Sian Hsien himself and his attendants. Only one man, the Mengkao, escaped. This Sian Magistrate was said to be very friendly with Mr. Thompson and frequently visited him, watching the progress of Mr. T.'s new house that was being built, or talking on ordinary matters and the current news of the day. The people suspected this good man of being in secret league with Mr. Thompson and the rest of the foreigners in the city. "Yu Waikwohjing Szet'ung." They therefore made for Mr. Thompson's house, killed Mr. and Mrs. Thompson, their two children, and then our three female teachers Miss Manchester, Miss Sherwood and Miss Desmond. About this time Mr. and Mrs. WVard had arrived from Ch'angshun, with their little baby about a year old, and Miss Thirgood. Their boat stopped outside the Seding gate, and here the T'ufi or local banditti met them, and slew them and slashed them to pieces. "Tsahleh myuohtsiang." The people of the city killed the Kolaohwei and the Thompsons and sisters inside the city, and the local banditti killed the foreigners from Ch'angshan outside the city. From Lungyin, Wong Yindz and family-in all seven persons-have had to flee to our place for their lives, losing everything they had. The chapel was pulled down and premises all looted. This used to be Mr. Thompson's drugseller. He was evangelist at Lungyin for several years, and he also had a drugshop at Lungyin. He told me that the dead (who had been killed inside the city in the riot) lying about the streets were thrown into our Chapel, and the grounds were being made into a grave yard. Fifteen hundred soldiers are said to be now about Kiangshan fighting these Kiangshan T'ufi, whom the soldiers find to be very stout, brave banditti. The soldiers have been shooting down 
without the slightest excuse charcoal burners whom they met on the roads in the prefectures of Wenchow, Ta'ichow and Ch'uchow. This indiscriminate shooting has been put a stop to. The soldiers are said to have taken these charcoal burners for T'u-fi or local banditti. I cannot vouch for the truthfulness of all the above statements. Do you send others to inquire and investigate matters at $\mathrm{Ku}$-chau and see if their report agrees much or in general with mine."

Be it remembered that there is a Taotai at Ku-chau, and Ch'angshan is in his district, or circuit rather, as well as Kiang-shan Hsien. Had he taken proper precautionary measures the missionaries in the city at least would not have been massacred, for the Taotai has plenty of soldiers and authority enough to suppress the people of his own immediate locality. Mr. Thompson's house is not so very far from

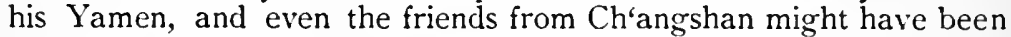
provided with a suitable escort to conduct them from their own city to the Fu or prefectural city where the Thompsons and our three sisters lived. It is the chief magistrates who are so much to blame for the massacres of innocent men, women and children, and not the district mandarins, who have no soldiers save a half-dozen ragamuffins who dare not-if they knew how-fire a shot into the murderous mobs that rush indiscriminately upon poor helpless women and children, even should the Hsien have courage enough to give such an order. At K-in-hwa remember also they were not ' $T$ ' $u$-fi, but the roughs of the city, who destroyed the American Baptist premises. At P'u kiang and Choo-ki, the house and chapels were all pulled down and looted by the local roughs, and not by banditti such as those of Kiangshan, who cut to pieces our dear friends the Wards with their little boy, scarcely a year old, and poor Miss Thirgood. Alas! alas! This is not true martyrdom! This is not dying for a principle! This is indiscriminate slaughter of Christian and heathen alike. For one Christian killed a score of innocent people either of the shops or of private houses, those who have money, are shot down by Kan-su troops and Boxers in the north; and by T'u-fi or Banditti in the south.

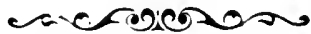




\section{NEWS FROM THE YANGTZE.}

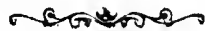

On August 12th the Japanese Consul and his community, from Chungking, arrived at Ichang. They reported all quiet up to their start. Twenty-five of the Church Mission also arrived. At the request of Mr. M. F. A. Fraser, the Japanese Consul kindly consented that the Taiyuen should be detained for the one remaining boatload of the Church Mission, although none quite understood why they should not come down in one of the other steamers in port, and thus the Taiyuen, decidedly overfull, only left Ichang after all at 4 a.m., August I $3^{\text {th, }}$ still without the missing boat, but with three versions at every meal.

The last news there from the West was two telegrams, one that the authorities said they could not much longer hold the rabble in check, the other that the Viceroy was putting out the Imperial Edict urging the people to drive out the foreigners. At Hankow, however, the French Consul had got a still later telegram from Mr. Bons d'Anty saying all was quiet in Chungking, so we still hope for our belated friends, although their position getting through Chungking is an altogether different one from what it would have been had Consul and Customs and all of us remained there to welcome them.

As it is the gallant three seem to have managed well. Professor Brill went up the Little River in a small boat to meet the Church Mission and warn them all to make straight for Mr. Archibald Little's house where they were all put up for two nights, and $\mathrm{Mr}^{\text {r. Nicolson }}$ did the honours, and Mr. Hyslop engaged fresh boats for them. Thus they never went into Chungking city at all. They all seemed very well, and calm and collected, although suffering of course from the intense heat into which they found themselves suddenly plunged from their mountains.

At Hankow a party of China Inlands had just arrived from Shansi, if they could be said to arrive when most were dead. Their treatment had been so cruel and horrible, their sufferings so greatsomeone else may perhaps describe them. But probably none ever will in a newspaper. Two of their dead they brought with themMrs. Cooper and Miss Huston.

Dr. John officiated at the funeral service, a group of Missionary men, sun hatted, standing round. At first his voice trembled, but as 
he read on, the beautiful words of the service scemed to bring peace and calm to all, and realised Mrs. Cooper's last joyous cry: "Rest : Rest," as at last her spirit was given release from the poor mangled body. Another lady had been beaten to death almost at the beginning of their 27 days of stonings, beatings, starvings. A poor Chinese man on one occasion came out from a city, on purpose they thought, with hard boiled eggs which he spread before them. Native Christians, who had escaped, prevented them from going to Tai-yuen $\mathrm{fu}$, telling them 30 Europeans were being burnt in one house, others in another. It is hard to think how the Chinese are ever to be taught not to misuse foreigners, seeing these poor sufferers. Yet doubtless the lesson will be learnt. Lieut. Chilcot and ten men, together with Mr. Bertram Giles, had just started from Hankow to man the s.s. Pioneer on her return voyage to Chungking, but had to put back, one of the men being seized with sunstroke.

At Kiukiang a blue-jacket had just died of sunstroke. Can nothing be done to deliver these brave, patient fellows from the cruelly heavy flannels they are made to wear by Navy regulationswhich really were not drawn up for the interior of China? And could not the guardships at the several Yangtze ports be allowed to erect mat awnings over themselves after the Chinese fashion, and for the most effective protection, especially if put high enough, and stretching out far enough. The poor Woodlarks are being much tried at Ichang, whilst at Kiukiang they boasted they had just had their hottest night.

Nine or ten arrests have been made there of men supposed to be of the same company as set Tatung in a flame, among them, curiously enough, two Indians.

It is strange to find that it is only the English ladies who have left the River ports. At Hankow the Belgian and French ladies seem all to be there still, whilst of Englishwomen I could only hear of the Commissioner's wife and the Consular Constable's.

At all these ports things were said to be much quieter than they had been. But at Shasi most markedly so. There, it seemed, there were placards out urging the driving out of the forcigners and it was impossible to get to see the oficials, till the news of the taking of Tientsin arrived. Then they came round of themselves all politeness.

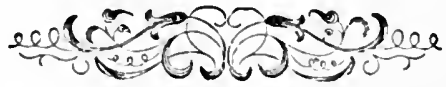




\section{THE SITUATION IN SZECHUAN.}

The prospects of the Boxer trouble spreading to the west and south-west are unhappily not remote. In spite of official reticence, too of ten another name for ignorance, the conviction that something unusual and alarming is transpiring at Peling and along the coast has steadily fastened itself upon the popular mind, and a recrudescence of the old anti-foreign feeling is making itself felt.

At more than one point distinctively Boxer placards have been posted threatening the foreigners and inciting the people to rise against them.

To the west and southwest of Chen-tu raids have been made on the Catholic Missions which have been looted, their contents sold on the public street and the premises afterwards burned. In some instances the men in charge of the missions have contested their position with the assailing force uselessly.

The local authorities have been powerless to act while on the whole willing to give protection.

In one instance, where twenty braves under the lead of a small official were sent to protect a place after it had been rioted, the entire force, including its leader, decamped at first sight of the enemy. On hearing of this the district magistrate threw up his office, being unable to control the situation.

Trouble has also broken out in the district raided two years ago by Yu Mantze, a not surprising matter when one has regard to the antecedents of the people of that locality. One Protestant missionary travelling from his station in obedience to the Consular orders was, with his wife, subjected to several riotous demonstrations on the way and his escape is a matter for thankfulness no less than for surprise.

The general and prompt attention given to the notification sent out by Mr. Consul Fraser, however, served to avert graver difficulties. Whatever may have been the feeling at the only port of Szechuan regarding that somewhat discussed order, it is generally acknowleriged that the Consul did a service not only to those immediately involved by the order lut also to the wider interests which he represents. If Szechuan is saved from a repetition of the horrors that have stained the northern provinces the credit of it must be largely 
given to the British representative there for his prompt and energetic action.

It was known more than a month ago that in certain high quarters a plan was entertained against the lives of the missionaries. 'lo gather them all in three convenient centres under the plea of protection and then massacre them, was the proposal made. When one remembers that in 95 the riots were conceived and practically commenced in a certain notorious Yamen in Chentu, there is the less room for doubting what on its face bears the hall mark of probability.

The Viceroy of Szechuan may be willing to preserve order and all wish he may succeed, but who will stand guarantee for the performance?

Already both Catholic and Protestant Missions have suffered in the present trouble. If the word of business may be accepted, trade is at a standstill, while mission work is practically discounted nowall share a common loss.

If the mission agents had allowed themselves to defy their consular authority, and thereby add to the unhappy complications of the present conflict, it is difficult to see of what avail their services could be when shut up tight in certain selected centres, a cause of anxiety to Chinese and foreign officials alike and utterly unable to succour their harassed and suffering co-religionists among the Chinese in the smaller towns and solated villages. There are grave elements of danger in Szechuan and the best that can be said of the matter now is that, during the suspension of ordinary relations with the province, panic should be avoided, care exercised, and a return made when the clouds have rolled by.

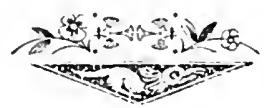




\section{WENCHOW AFFAIRS.}

The Wenchow correspondent of the "Shanghai Mercury" wrote on I 2 th August, 1900:-In the city everything is tranquil to all outward appearances, but, nevertheless, trade is entirely dislocated for the time being, as in view of the present critical situation merchants do not feel justified in engaging largely in business. Almost the whole of the export cargo which the Poochi takes away this time consists of about 350 chests of tea. Moreover, since that vessel has come under the American flag the importation of opium has as a matter of fact ceased, and the want of the drug is being keenly felt.

The Boxer leaders, of whose capture you were informed some weeks back, have now been removed to Hangchow, there to await the Fut'ai's pleasure. They were taken away from the port surreptitiously by the Government launch Sin Pao-shun, which crept in quietly at $S$ o'clock in the evening of the 7 th, and stole away again next morning at daybreak in the same silent manner. This was done to prevent any attempt at rescue on the part of the adherents of the prisoners.

It is with much regret one learns that the report of Chuchou fu having fallen into the hands of the secret societies is confirmed from other sources, particularly as eight members of the Inland Mission residing there are said to have lost their lives.

There arrived here from Chuchou to-day five ladies and two gentlemen stationed there belonging to the German Mission, and three more members of the same mission are expected here in a day or two. Those who are already here are leaving for Shanghai by this morning's steamer. They report that they were very well treated by the officials inland, who, however, advised them to leave, as certain anti-foreign feeling was manifesting itself, which in a great measure was due to the wild rumours which had been circulated upcountry as to what had occurred here and at Pingyang. They were provided with an efficient military escort all the way down and promised that their goods and chattels should be well cared for during their absence. Chuchou itself is in a bad plight owing to the recent severe floods, which have hardly left a single building intact, and to this is added scarcity of rice. Under the circumstances it is no 
wonder that trouble is imminent, and the officials were certainly right in advising the foreigners to go.

A new Magistrate came by the Poochi-a Hunanese-and it is currently reported that the de facto Taotai of this port, also a Hunan man, will shortly arrive to take up his appointment, thus relieving his locum tenens, our present well-meaning but weak-kneed Taotai Wang. Whether this shuffling of official cards will prove beneficial to us remains to be seen. There also arrived by the Poochi this time a weiyuan from the Fu-t'ai specially deputed to inquire into the recent local troubles. The officials here don't in the least relish his coming, and when he calls on them offer the most paltry excuses for not seeing him.

The 500 soldiers brought here by the Chaowu from Ningpo. a couple of weeks ago have returned to that port by the same vessel.

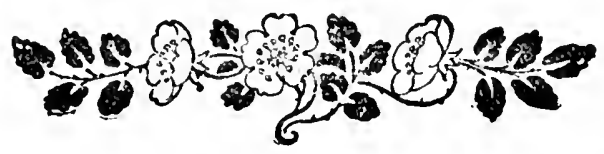




\section{THE FIGHTING AT NEWCHWANG.}

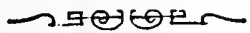

6th August.-On Saturday 4th, at 7.15 a.m., over I50 Boxers made their long-promised attack on the foreign settlement. They were armed with swords, knives and spears. An attempt was made by them to cross the barrier constructed near the river-side. Several members of the Volunteer corps were at once on the spot and attempted to drive them off by firing several blank shots. This, however, had not the desired effect, and as reinforcements had arrived fire was opened in earnest and resulted in Io killed and as many wounded; the rest beat a hasty retreat. Some 20 Russian marines had by this arrived who, assisted by the Volunteers, poured a few volleys into the retreating mob. The leader of the Boxers was pluckily captured by a Volunteer and was afterwards shot by a squad of Cossacks and Volunteers. He was most profusely covered with red ribbons and his flowing hair was adorned with similar material of red and yellow; his facial expressions reflected those of a hardened sinner.

At about 9 o'clock the Boxers were joined by some soldiers and were seen near the city walls amongst the reeds and high grass. From that time and until one o'clock some 400 Russians kept up an incessant cannonading and rifle fire. Reinforcements arrived in the shape of 500 cavalry and several companies of infantry. The Russians soon gained the advantage, and forced the enemy back into the city.

In the meantime the Russian gunboat Gremiastchy had moved to a position opposite the native city and another gunboat took up a position near the fort. At 2.30 p.m. the Gremiastchy opened fire with shrapnel, directing her shots well beyond the heart of the city and the enemy was seen streaming out of the city in an opposite direction. The other gunboat and the land forces attended to those. The 500 cavalry especially did good execution, and the slaughter of Boxers and soldiers became general. With short intervals the firing continued for three hours and but few shots fell into the main part of the city, which was on fire in several places, without, however, doing much damage. At one time the Chinese replied with machine guns and rifle fire and bullets were heard whizing dangerously near people in the Settlement.

The Taotai had meanwhile made off towards Tienchwangtai, I5 
miles away. At 6 p.m. the general commanding the Russian troops sent a messenger to the guilds that if all arms were brought in, the city would be spared. These conditions were accepted and hostilities suspended. After sundown the Russian naval flag was hoisted at the Customs flagstaff, where it proudly continues to fly. The Russian Admiral arrived yesterday and it was decided to establish a provisional government with a civil governor as its head. The Customs is to function as heretofore until a final settlement is arrived at. An inspection of the city on the following day proved it deserted. With the exception of the public buildings no signs of looting were seen. Very little damage was done by shells in the main parts of the city, the missiles being chiefly thrown beyond at the outskirts. The two Japanese gunboats in port took no active part in the fight.

The Boxer element is completely wiped out and there is at present no fear of attack either from local rowdies or soldiery, and the whole place is policed by the Russian forces. The only fear of attack to be anticipated is from the north where Imperial troops and hordes of brigands have joined hands. It means a deal of hard fighting to subdue the entire district. Where a few day ago Boxer flags were seen there are now innumerable miniature Russian flags and foreign signboards over Chinese shops, taken down before, are being restored. A Russian trooper arrived on Saturday from Port Arthur and while passing the gunboats engaged in firing the band struck up lively tunes and the cheering was incessant. The railway between this and Port Arthur remains still interrupted.

\section{Proclamiation by Russian Admiral.}

The following was circulated by the Consular Body on the 7 th inst :-

Yingkow, 6th August, 1900.-Sir,-The hostile behaviour of the Chinese authorities, who had first encouraged the rebellion and then declared that they could not maintain order, ended in the open attack on our forces placed in the city in accordance to the wish of the Consular Body. During the said attack the Chinese authorities had fled leaving the town to its fate. The avoid disorder and looting by the Chinese mob and with the object of protecting the commerce of the port and the property of foreigners the Russian Military Authority found it necessary to place the town under the guard of the Imperial Russian troops. It may be added that the perfidious destruction of the Chinese Eastern Railway by the insurgents and soldiers also necessitated our placing in Yingkow a force of troops to protect the same. Nevertheless the Imperial Government tried to avoid the extreme measure, Yingkow being a Treaty Port. It is to be understood that the temporary administiation that is to be established, in the interest of the Russians as well as the foreigners and Chinese, will not infringe the rights and privileges which they have enjoyed previously in Yingkow.

The foreign community has to note that the sole object of the provisional Russian administration is to maintain peace and order and 
restore trade, and I hope in these endeavours to have the sincere support of the Foreign representatives.

\author{
I have, etc., \\ Your obedient servant.
}

\author{
E. Alexieff, \\ Vice-Admiral.
}

The Consuls of the Treaty Powers,

Yingkow.

\begin{abstract}
Messrs. Bush Brothers sent the following account of the fighting at Newchwang:-
\end{abstract}

Newchwang, 6th August.

Owing to an attack on the Settlement made by the "Boxers" on the morning of the $4^{\text {th }}$ inst., followed up by rifle fire from the soldiers and licensed highwaymen, the Russian gunboats opened fire on the Chinese Town, which resulted in all the native combatants flying southwards towards the plains, where they were intercepted by the Russian fleld artillery and cavalry.

The bambardment was stopped to allow our Mr. H. A. Bush and some of the merchants, accompanied by a lieutenant, to proceed down and get the Guilds together. Some eight native merchants with one of the Yamên officials-the Taotai had fled, having been threatened with death by the "Boxers" for endeavouring to clissuade them from making an attack-were found, and returned with the foreigners to the settlement, where they had an interview with the General, who stopped further bombardment on the condition that all arms would be given up by ro a.m. the following day. The same evening the Russian Naval flag was hoisted at the Custom House by order of the General. On the 5 th inst. our Mr. H. A. Bush, a few of the foreign merchants, and Mr. Schmidt of the Russo-Chinese Bank, accompanied the troops on their march into the native city, to assist in procuring accommodation for the soldiers appointed to police the town, and to prevent misunderstandings between the Chinese and Russians. ViceAdmiral Alexieff arrived yesterday and informed the deputation of foreign merchants who called on him that the Russians would administer the town, and that the dues would be collected by the Customs as heretofore, but held pending final settlement. But for the barbarous behaviour of the Cossacks it would not be difficult to reassure the merchants. The native city is quiet and hongs are all closed.

Very little damage was caused to the town by the bombardment.

Newchwang, gth August.

Everything is quiet, and some people are returning to their homes in the city, but no business is being transacted. There are 7 Russian, 2 Japanese and I British men-of-war in harbour. Com- 
mander de Collogue of the Russian gunboat Otvajny has been appointed temporary governor of Newchwang. In last Saturday's fight I,500 Boxers and soldiers were killed, and thousands wounded, the Russian loss being trifling. It was simply a great slaughter. The soldiers and Boxers had a fight between themselves at Tienchwangtai, the former blaming the latter as having caused all the trouble. Over 150 Boxers were killed in the fray. The Taotai has taken train at Tienchwangtai for Shanhaikwan, taking his belongings with him. The 600,000 piculs of beans lying for some weeks at Tienchwangtai are being conveyed down into port and hundreds of lighters and cargo-boats may be seen coming down daily. The Russian transport Ariel left yesterday for Taku with I,500 troops. There are no merchant ships in harbour. The ladies and children sent to Japan before the trouble are now being recalled.

\section{Newchwang, I I th August.}

Mr. Ostroverkov, Consul for Russia, has been appointed temporary civil Administrator of Newchwang and Commandant de Collogue, of the Russian gunboat Otvajny, military commandant. The British gunboat Pigmy and the U.S. cruiser Nashville arrived two days ago, but both have left since. There remain 5 Russian and 2 Japanese war craft. There was heavy cannonading heard from the eastward yesterday and lasted quite five hours. It appears the Russians attacked the Chinese troops and Boxers in force between Tahshihchiao and Haich'eng and defeated them with heavy loss. The Chinese have fallen back on Haich'eng, 25 miles away. The Chinese merchants continue the re-export of goods and the shops still remain closed. Beans and beancalie are coming down river in very large quantities, but transactions are effected for cash only; this commodity being scarce very little changes hands. There are two merchant steamers in harbour.

\section{Newchwang, I5th August, Ig0o.}

On Sunday, I2th, the Russians encountered the Boxers and Chinese troops near Haiching and some hard fighting was done on both sides. Eventually the Chinese were repulsed and four Krupp field guns and large quantities of ammunition fell into the hands of the Russians. These guns are far superior to any the Russians have in this district and will prove a decided acquisition. The Russian Korcely was.sent for and arrived yesterday. Several thousand troops are also expected, as Chinese posters from Chinese sources warn the populace that Yingkow will be attacked and advising the people to leave.

Four days ago it was known that 500 mounted soldiers had arrived at Tienchwangtai from Shanhaikwan. These with other troops and Boxers brought up the total to 1,000 men. Some anxiety was felt which increased by the appearance of several hundred mounted Chinese soldiers near the Russian settlement on Saturday night last. The garrison at that place was small at the time and the foreigners at the place spent the night on board a merchant ship 
which was moved near the place. Fortunately, through the Chinese defeat at Haich'eng, the Tienchwangtai band drew off towards the former place. Two more Maxim guns are landed in the settlement. The lekin office in the city has been re-opened and the work is superinended by Mr. A. Schmidt of the Russo-Chinese Bank, assisted by local customs officials. The Russian authorities have issved a proclamation requesting Chinese to stop, which has had the effect of arresting the exodus to a certain extent. One or two ships arrive and depart daily, but not much business is done.

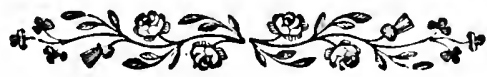




\section{A NATIVE'S EXPERIENCES IN PEKING.}

Ma Loh T'ien, a former pupil in the Chefoo Mission School, has lived in Peking the past year and made his escape on June 26th. A Manchu soldier befriended him by lending him a soldier's garment and escorting him out of one of the city gates.

Mr. Ma says that since the Chinese New Year Boxers daily met in the temples and Yamens and were drilled in the use of the sword and exercises supposed to make them invulnerable to foreign swords and guns. It was reported that more than one half of the Imperial soldiers became Boxers and also attended the drill exercise. All the members of the Boxer fraternity were readily recognized by a peculiar mark on the forhead made by knocking the head on the brick pavement whenever they met for drill. About the gth of June word came to the city that the Boxers had captured the hien city of Chohchen and were strengthened by a large number of recruits from the Shantung province, also that not only the native converts in the city but in the entire district were massacred and their homes looted and burned, also chapels were burned.

Large numbers of Boxers came to the City and increased daily until all fear and secrecy disappeared and they drilled in open day in the public streets. Officials, wealthy men and merchants contributed either silver or grain for their support. Later on every one said and believed that the Empress-Dowager gave orders to pay the Boxers money from the public treasury. At this time new proclamations exhorting all to keep order were being constantly posted but torn down immediately. The people said these proclamations were solely intended to blind the foreign officials and keep them from learning the true situation. The people said if the officials were honestly striving to protect foreigners and native converts why did they encourage Bosers to drill in their yamens and contribute liberally for their support when they knew they were intending to massacre all as soon as the set time arrived. At night the Boxers threw pieces of brick and stone, also burning faggots, into the courts of foreign houses. About the 12th or 13th of June, men women and children, in all probably one hundred Protestant missionaries and about two thousand native Christians, assembled at the compound of the American Methodist Mission. Many of the natives were refugees from the 
country and some were covered with wounds and scars. Many were the only survivors of the family. At this time there was a guard there of about twenty foreign soldiers. No sooner had the missionaries and native Christians left their houses than the rabble, assisted by the Imperial troops, began to loot. Furniture, doors and windows were carried in open day along the public streets. After everything of value was secured the houses were set on fire. After a day and night spent at the Methodist Compound Mr. Ma was afraid to remain longer and escaped to the house of a friend living outside of the Chen Gate. There Boxers set fire to a large drugstore in which it was said were foreign drugs. Large native shops where clocks and other foreign articles were sold were also set on fire. Everything foreign must be destroyed. The fire spread until it was estimated that no less than 2,700 large business shops and residences, not counting many smaller ones, were entirely consumed. Thus the chief business centre in Peking was blotted out. The Boxers killed anyone they saw either trying to escape with valuables or trying to put out the fire or protect property. There were no Christians in that part of the city, or rather suburb. During this burning the streets were crowded with Boxers and sight-seers, but, strangely, no one was suffered to loot.

Mr. Ma became alarmed and fled again into the city and spent a week with a friend living about 200 yards from the Methodist Mission.

About the 20 th or 2 Ist June the German Minister, when riding in a chair, was shot by lmperial troops. The people all said they must have received orders from the Empress-Dowager as they would not have dared to do this on their own responsibility. The same day all the Missionaries fled for greater safety to the British Legation, and the native Christians to a large Yemen close by. It had been vacated by the native officials a few days before. There was a small guard, he thinks, of French and American troops on the street during this removal. During the afternoon of the same day a military officer rode down that street near the Foreign Legation carrying a flag and notified the Imperial troops that it was the wish of the Empress-Dowager that they should kill foreigners wherever they could find them. Later in the day the Boxers crossed the Legation Street and had an encounter with the foreign guards. The result was that the street was soon filled with dead Boxers. From this time till Mr. Ma left, June 26th, there were daily conflicts between the Foreign guards and the Kansu troops led by General Tung Fuhsiang and Chihli troops led by Gen. Jung Lu. Same days it was said from 200 to 300 native troops were killed, at other times 30 or 40 , and the onlookers were compelled to carry the dead bodies out of the city. The remarkable thing was that the Foreign troops were seldom seen, as they kept behind walls. Their firing was so deadly that the native troops did not dare to travel on the Legation Street, or even on the wall within reach of Foreign guns. The native houses between Legation Street and the city wall, also near the British Legation, were soon all burned and the inhabitants killed by native troops.

It was reported that one day the Foreign Guard rushed into a 
temple which was filled with Boxers, none of whom escaped. Also that the Foreign troops ascended the city wall at the Chen gate and went to the Ho-ta gate, where they met Ioo Chinese troops, only eight of whom escaped with their lives.

It was also said that the shooting of the Foreign troops was so deadly that the Chinese soldiers would not dare to approach. Finally they decided to surround all the Foreign captives, cut off all supplies and starve them. I was said that fully 30,000 Chinese troops undertook this task. It was reported that the Chinese officials were filled with terror by the report that near the German Legation was erected a fort on which was a cannon trained on the Tartar city.

It was said the same was true of the Catholic Cathedral. So great was the fear that the Tartar city would be set on fire that one of the Princes went and spent a day and a high official several days trying to restrain the Boxer soldiers.

After the first day or two it was said the Boxers seemed to subside, leaving the Imperial troops the task of attacking Foreigners and firing into the Legations. The houses of native Christians were looted and burned, and the Christians massacred wherever they could be found. Women and children fleeing from the vicinity of burning houses were killed, and many who were not Christians also perished.

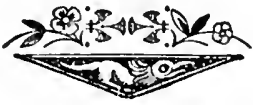




\section{K I A T I N G.}

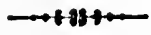

July I2th-CRumours of the happenings in and around Peking have gradually spread, causing a certain amount of unrest among the people. The usual threats of expulsion or extermination were repeated more than once, but the days appointed for carrying out the threat passed off quietly, the officials showing by their activity that they were prepared for any emergency.

Nothing serious happened until July 12 th. That evening lightning struck the Baptist Mission Chapel in this city. No damage was done beyond splintering one of the large ports, but a meeting was in progress at the time and the news, with many embellishments and exaggerations, spread like wildfire. The Chinese consider that none but the worst of criminals are dealt with in this manner by the gods, and the report that the foreigner was not only killed but lay a blackened corpse confirmed them in their suspicions, so the cry was raised, "If the thunder god beats the foreigner why should not we assist him." The next morning a surging crowd surrounded the place almost before the missionary knew what was taking place, and it was only the prompt action of the official which saved the place. He came with his runners and remained all day, and at night the compound was guarded by sixty soldiers with the satisfactory result that in a day or two all immediate danger had passed away. There are several who look upon the lightning stroke as providential, leading to premature action on the part of some who were plotting mischief, but the prompt action of the authorities has cowed them for the present.

Some of the Missionaries had gone to the mountains for a much needed rest, and others were preparing to follow, when H.B.M. Consul's order calling upon all British subjects to proceed without delay to a place of safety took all completely by surprise and put a stop to preparation of that kind. The people were as kind as ever, the officials were active and apparently prepared to keep order and protect life and property. The missionaries could not understand the situation so a telegram was despatched stating facts, but the answer was "deliberate opinion not altered by ephemeral local conditions." Shortly after a cable from the Home Secretary of the Canadian Methodist Mission ordering the members of that Society to withdraw was received by the Consul and forwarded to Chentu. However loth the 
Missionaries might be to leave their work there was no alternative but to "obey orders."

The workers in Yacheo have arrived here and expect to proceed down the river to-morrow. They report that a Catholic Mission 40 li from Yacheo was rioted and the priest in charge barely escaped to that city. The workers in Chentu leave to-day, those in Kiating to-morrow. All quiet although there is some suppressed excitement on the street, due no doubt to the knowledge that the foreigners are preparing to leave.

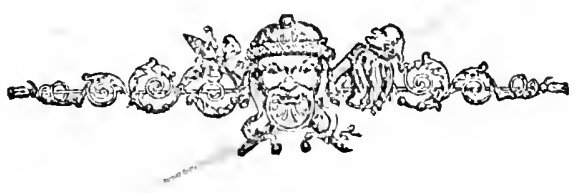




\section{THE TROUBLE AT AMOY.}

26th August.-Some months ago a meeting was held in the Amoy Club amongst a few trading members of the community for the purpose of formulating a scheme of defence of the Island Kulangsu.

A committee was appointed, rules, signals and places of assembling laid down, but the unfortunate outsiders are to-day in the dark about what the Amoy Defence Committee has decided upon, and if the emergency should arise for the Amoy and Kulangsu residents to seek shelter they would have to take their risk and run about like a fiock of sheep without a leader, as so far nothing has been done. The defence committee appointed is not known, their plans not communicated to the residents, and they are just where they started some months ago, and the mountain of strength has given birth to the proverbial mouse, and this does not add to our sense of security. In the event of trouble there would be a grave charge to be made owing to the supineness of the various representatives, and the credulity of the senior Consul.

A rifle club has been started amongst the residents of Amoy and good practice is put in at the Rifle Range, and shooting is steadily improving.

H.B.M.'s Consul has greatly assisted the members of the Club, in lending some of them Martini Rifles and allowing them to get their ball ammunition at the Government price. Others use Winchesters.

The Commissioner of Customs has served out Winchester rifles to his staff, with 50 rounds of ammunition.

All missionaries have been called in from the outlying stations and our community is looking up in numbers.

Up to now, the natives of Amoy have been perfectly quiet and orderly, and no trouble was anticipated, but the mine has been exploded, and the usually quiet and orderly natives of Amoy are in a great state of excitement.

During the trouble up north we have been protected by one or two Japanese men-of-war, and for the last three weeks the Idzumi (late Chilian cruiser Esmeralda) and Takachiho, both fast cruisers, have been in Amoy for our protection.

On the $24^{\text {th }}$ inst. at about 2 a $\mathrm{m}$. the Japanese Temple at the back of the Foreign Settlement was burned down, and during the fire a landing party, fully armed, from the Japanese man-of-war, landed and visited the scene of the fire. During the day the British Consul 
sent out a circular notifying the community that the fire was caused by a mob of rowdies, and that no trouble was anticipated. The Chinese version is that the Japanese priest could not pay the rent of the house, and that he had not paid the rent for many months, and to cover up his doings he set fire to the temple.

On Saturday, the 25th inst., at I p.m., the Japanese men-of-war landed on the British concession 100 men fully armed, with one machine gun, and placed sentries at the Taiwan Bank, and all along the Back Street (Market Street) of Amoy. This naturally greatly excited the Chinese, and the Amoy Bund was crowded with an excited and inquiring Chinese crowd. The sailors were not withdrawn before Sunday morning, when they with others, 250 strong, with two machine guns, landed to the south of the British Concession, placed sentries on the hills and along the roads leading into Amoy. The aproaches to the Japanese Consulate in Kulangsu are protected by pickets of sailors, night and day.

All these warlike demonstrations by the Japanese were uncalled for and the Chinese are now giving trouble. Boxer placards have been posted all over the place, and the Chinese are now leaving Amoy for up country in the steam-launches at the rate of 3,000 per day and many shops are closed. Trade is at a standstill. Coolies for unloading steamers are not to be had, and all is pointing toward serious trouble in Amoy.

The Island of Kulangsu is our haven when trouble begins in earnest, and the few of the community that are residing in Amoy (the Customs outdoor staff and two assistants in a Foreign Hong and the Hongkong and Shanghai Bank) will have to leave and go across to Kulangsu. I hear by rumours that we are all to make for a certain place-puzzle-How to get there? And what to do when we arrive, at the "certain place" is only known to our Defence Committee; and I am told they have not made any arrangements in regard to food, water, ammunition, etc., and as trouble is now brewing, the so-called Defence Committec should let outsiders know what is what, and communicate to all the Foreign community their plans-if they have made any.

I think we can trust the landing party from the Japanese men-ofwar in harbour to take care of Kulangsu, as they, as far as I have scen of them, are a smart and active, well disciplined lot of men, but at the same time the many able-bodicel men in Kulangsu should try to help themselves and not totally depend on the "Jacks" from the Rising Sun for their protection. For if the Chinese should rise, the Forts in Amoy could shell the principal houses on the island of Kulangsu. "Then women and children and "old" men have to be taken to a place of refuge, what place? and will they have food, etc., for their comfort?

I am not an alarmist, but I look the situation straight in the face and wish to point out how helpless our women and children would be under the present organisation. 


\section{SHANSI MISSIONARIES.}

Definite news has come from Hankow of the arrival there of another party of Shansi Missionaries. These include Mr. and Mrs. Lutley, Miss J. Hoskyns, Miss A. Hoskyns, Miss Johnson, Misses French, Gauntlett, Higgs, Palmer, Rasmussen, and Mr. and Mrs. Dreyer.

Two children of Mr. and Mrs. Lutley died on the way down. It is not thought that this party has suffered from ill-treatment, being known to have been under official escort all through Honan. The two children reported as dying would most likely have succumbed to the unavoidable hardships of travelling at this season of the year.

From reliable sources also we hear of a party of ten or twenty missionaries from Shansi who have arrived at Ulinfu, in the north of Shensi. They are reported to be in trouble with Boxers, but it is hoped that through the known friendliness of the Governor of Shensi, who stands out so favourably, in sharp contrast with Yu-hsien, Governor of Shansi, some means will be found of bringing them safely down to the coast. Who these "ten or twenty" may be is not at present known. They may be missionaries from any of the stations of the different missions in the north of Shansi. Further news of this party will be looked for with great eagerness by the many friends of the missionaries there.

No confirmation has been received of the "thirty" who were rumoured to have escaped from Tai-yuan-fu, and also said to be pursued. Those who are said to have reached U-lin may be from Taiyuan-fu, but the presumption is that they have come from districts north of Tai-yuan-fu.

The flight of the Empress-Dowager into Shansi cannot possibly make matters worse for the missionaries who may unfortunately be still there. Yu-hsien has already "touched bottom" in his treatment of them, but should Her Imperial Majesty reach Shansi and Singan, then it is to be feared that Shensi will no longer be that safe asylum for foreigners which it has hitherto been. It is to be hoped, however, that by that time fear of the consequences may so possess the minds of the Empress-Dowager and her court that no vengence will be taken on friendly officials who have so nobly striven to do justice and mercy to missionaries and converts alike.

The latest news of Yu-hsien is that he has a band of some 
hundreds of mounted Boxers who are visiting in turn each district in Shansi and compelling officials who would otherwise be friendly to hunt out the Christians, torture and destroy them. Immediately after his arrival in Shansi, in the latter days of April, he began operations by sending out Boxer instructors to the different Hsiens, who not only began to enlist recruits but also by placards prepared a hitherto friendly populace for what their Governor has since got them to do. Till his advent in Shansi that province was perhaps of all the eighteen the province in which missionaries and foreigners generally could feel most secure and were least likely to meet with insult or injury, and now of all places in China it is the most unsafe. Yu-hsien, the Father of the Boxers in Shantung, has again earned this title in Shansi. 


\section{THE POSITION AT TIENTSIN.}

We are indebted to the kindness of Dr. Hykes, of the American Bible Society, for the following extracts from a letter which has been received from Mr. Gammon, the Tientsin agent of the Society, dated 23rd August:-

I find that soon after my departure a Chinese shell came into the upper storey, completely wrecking two rooms. 'The large bed, baby's crib, bureau, stairs and everything are simply blown to splinters; a chest of drawers full of clothing is to be remembered only by one of the boards that formed one side; the wall is destroyed, the floor blown up and a general chaos the result of this one shell.

As to the situation, I am sorry to say that I must change my views regarding the time when work may begin again, but that is due to a new factor in the calculation, and not to any error in the way I looked at it before. It is now certain that there will be an immense army of occupation here during the entire winter. The British have I2,000 troops coming in addition to those already here, and America will be represented by at least i I,000. 500 more marines and the 3 rd Artillery arrived yesterday. This means that every available shop, house, godown and piece of land will be occupied by troops-there will be little room for citizens, and, on account of this occupation, mission work will be entirely suspended except very locally. It is worthy of note that preaching has already been done in Tientsin city, and there is absolutely no reason why I cannot sell bools there.

You will have heard that Peking has fallen. I have always believed that our friends would be saved. Perhaps you have not heard that the Chinese had undermined the position (I suppose at the Legation) and that in a few days the whole thing would have been blown up. General Chaffee has the southern city, where all looting is forbidden, and he has issued a proclamation that fair prices will be paid the natives for provisions. This is a great contrast to other parts of the capital, where looting and burning is going on unabated. The Russians and Japansse now surround the Palace, which, for some reason, they have not entered. The Germans insist that everything be burned to the ground, especially the Palace, and I believe this to be the right thing, hard as it seems. The Chinese understand no other form of the display of power. Strange to say, in spite of the 
utter defeat of the imperial troops, the Boxers have not given up hope of success. On the day of my arrival (29th) they had assembled for another general attack on the settlement. The U.S. 6th Cavalry went out to meet them and killed four hundred, besides bringing in many prisoners. About 1,600 Chinese troops are with them. Of the prisoners, those who were found or seen with arms, or who had evidence of being Boxers, were shot on the 2oth, those supposed to be less guilty were severely flogged, their queues cut off and then turned loose, while some of the younger ones were kept for labour. There are fifty-eight prisoners ("Boxers") in to-day, taken by the U.S. Marines, who will probably be executed. This morning there was an engagement outside the mud wall, in which the Germans poured heavy shrapnel into the Boxers. It was soon ended. One Japanese was brought in wounded. The 6th Cavalry went up to Peking on the 2 Ist and had an engagement before they had gone fifteen miles. The river is in possession of the troops, and hundreds of Chinese boats are being sent up with army stores. \$5,000 rations for the Americans were sent up two days ago. The Russians have completed the railway as far as Yangtsun, and it will soon be through to Peking. I00 of the Peking people are now on the way down (from Tungchou on the river to Yangtsun, where they can take the railway) and will be here to-day. I shall be able to help them as to lodgings and food. It is wise to send them in parties of 100 as we could not take care of them all at once.

Adventurers are flocking here, many with loads of beer and whisky, and their devilish freight is allowed free transportation on the railway.

We are now under a provisional government in which all are represented, and I suppose it will be a long time before a Chinese Government is restored. It is now known that the Empress-Dowager, with the Court and 400 carts, fied to the capital of Shansi, and it is reported that the Japanese are after her. The latter I cannot confirm. The old lady put to death three members of the Tsungli Yamen before her departure, because they gave her good advice.

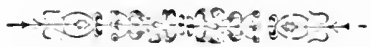




\section{TIENTSIN AND PEKING.}

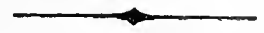

Dr. Hykes, of the American Bible Society, received the following letter from Mr. C. E. Gammon, the Tientsin agent of the Society, dated Tientsin, 25th August:- Out of chaos has come something like order. Our property will be taken over by the American officials, our house will be at least partly open to us (all, if we want it) and the Commissary Department of the Army are very kind in supplying us with every variety of American provisions at the Army rates, without profit, freight or duty. I am at present entertaining two Army officers, have had General Barry with me, and hope to have some of the officers who will be permanently settled here for the winter. By this means I secure my property, obtain many favours from the Army, and assist some of our officers to the comforts of home.

You have probably received many details regarding the fall of Peking, and I shall not endeavour to write many particulars, but some items may be of interest, It is now known that the Empress-Dowager and entire Court, escorted by Tung Fuhsiang, escaped from the ill-fated city after the Allies reached there. It seems too bad that the city was not so surrounded that none could escape. There was, comparatively, slight resistance to the entrance of the troops, but the firing from streets and walls after the Allies entered caused considerable loss. Our men, I am informed, were the first to enter, but after getting in were for some reason delayed, probably while waiting for orders, and the British came in behind them, passed them and relieved the Legations. I have heard the story of the siege from the lips of Mr. Chapin, and have been able to from a more or less correct opinion of the conditions then existing, Three boat loads of wounded soldiers and the American Missionaries arrived on the night of the 24th, and most of them are preparing to leave for home on the first government transport. The history of the siege reveals a strange fact. The Chinese were acting, as they supposed, on the defensive. They were constantly fearing an attack from the Legation allies, and it is for this reason that they bombarded them. For hundreds of yards the Chinese built barricades, some of which, on the wall, were actually captured by the allies, and at no time did they have the courage to make a rush, though by so doing they might easily have carried the place. The Empress-Dowager had given orders that no guns larger than, say, a 
six pounder were to be used against the Legation, and this saved them, for the larger guns would have utterly destroyed them, cooped up as they were in such limited quarters. 'The Chinese at onc time declared a truce, when it was agreed that firing and the further building of barricades should cease, but they were afraid of treachery on our part and in a few days began bombarding again. On one occasion they sent to the Legation a load of water-melons, which were acceptable, and I,O00 pounds of flour, which was not acceptable, since not even the Chinese Christians dared to eat any of it. Personally I do not believe it was poisoned, but they could afford to take no risk. This is to be analyzed, I believe. It was evident that two parties were at work, one of which tried to provide for them and save them while the others were doing their best to annihilate them. Some of the former were beheaded. While there is no doubt that they suffered many privations, the Legation people did not at any time bear a siege as severe as that of Tientsin. Theirs was more protracted and on that account they were reduced to eating horse meat and other kinds of repulsive food, and they suffered a much longer period of suspense, but in Tientsin the fate of the people hung more evenly in the balance, while the heaviest guns were brought to bear upon us, and instead of solid shell we were battered with shrapnel and segment. The Chinese here, too, acted upon the aggressive, while it is evident that in Peking the troops acted wholly upon the idea of self defence, that is, after they had been foolish enough to attack and lost heavily. True the Peking people were in danger as great as ours and for a longer time-or rather they might have been and suffered supposing they were, but the Chinese who opposed them did not realize that they had power sufficient to overcome them easily, to which we owe their salvation. But in spite of these facts, our friends suffered intensely, the strongest men becoming thin and the women changing terribly. They had a fearful and most trying experience.

As for Tientsin, I am more and more amazed, as I walk over the ruins and see the vast extent of destruction, that anything at all was left, more especially that any of us were left. I find on inspecting the Chinese ruins in the settlement and around the villages that many people were burned to death, their blackened remains being visible everywhere. Naturally the flames spread rapidly over the villages as they were lighted by our troops, and in the narrow alleys and crowded houses it was impossible for the people to escape in time. Words cannot paint the horrors of this war, and therc are some things - many things - that I could not commit to writing at all. Lives without number and property beyond calculation have been sacrificed to the ignorance of the people, and the end is not yet. I very much fear that the escape of the Empress-Dowager means further resistance elsewhere, and sincerely hope that she and her followers may be speedily captured. What the meaning of the immense armies on their way here is, I do not sec. Whether the Empire is divided up, as many think it will be, or a new government is set up, it will be a matter of months, and will be a most delicate matter to handle. There 
is grave danger of complications between the-Powers, and that will mean new terrors. It is perhaps wise for all who can do so to leave the country until matters are thoroughly settled.

We have received more information regarding the horrors of the massacre at Pao-ting-fu. Mr. Pitkin is believed to have been shot down first, and it is understood that our friends made no defence, telling the Boxers that they had always worked for the good of the Chinese and that if they wanted to kill them they might do so. After Mr. Pitkin was shot and beheaded, the others were bound aud taken three miles in the suburbs to the grave of a Boxer, where they were sacrificed. One or two of the ladies were unable to walk and they were carried. One of them begged for the life of her little girl, offering her own life freely, but the Boxers listened to no pleading and tears did not move them. Dr. Taylor worked with patients in the city almost up to the hour of his execution. After his death, and on account of his well known skill, his head was placed before an idol in the temple. The details are sickening, and it is to be hoped that some detachment of the allied troops may be sent to punish the people of that region, especially as it is reported that three or four foreigners are hiding in that vicinity. We do not any of us ask for revenge, but, as a home paper puts it, for justice. It is right and proper to punish crime, and Pao-ting-fu has fed one of the main roots of the growth of the uprising. Another fact of interest is that many in this vicinity who have done most to spur the Boxers on and to support them are the boatmen who have lost business on account of the railway. Indeed there are several villages composed wholly of boatmen and their families, and these have supplied the most bitter and savage of the Boxers. To them is probably due the destruction of the railway, and that was the beginning of the greater outrages. I have remarked before on the injustice of laying the present trouble at the door of the missionary. The Chinese (with the exception of the priests) are greatly indifferent to religious work, and ordinarily, while they might not take to the "foreign religion," they would not oppose it. But when native official corruption, drought and things of that nature, which affect the people so seriously, are supposed to be due to the work of missionaries, as the ignorant masses have been taught to believe, and when they see their territory seized by foreign nations and they are told that missionaries are the agents for this work, it is natural that they should rebel, and natural that they should hate every foreigner. I maintain that the Christian religion, as a religion, has nothing whatever to do with this trouble. The true cause is the charge that all the miseries the people suffer are due to foreign methods. They do not accuse us of teaching evil things, but they do accuse us of aiding our governments to seize territory, of bribing the native officials, of causing the heavens to burn their fields, of stealing their children for medicine, and many other things of like nature. 'The root of the trouble is therefore the terrible conditions under which they live, and which a few skilled leaders are able to trace to the missionary for the advancement of their own evil designs. The 
drought is not due to any religion, nor is the kidnapping, nor the corruption which exists in every branch of the Chinese official service : why then blame the missionary? However, this is a question that needs no argument.

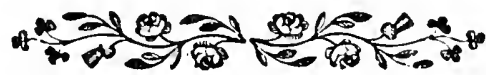




\section{TIENTSIN NOTES.}

August 27th.-On Saturday the first contingent of the lately besieged in Peking arrived here-some forty Americans, mostly missionaries. They all looked decidedly thinner and more careworn than they did two months ago, but it is to be hoped that sea breezes may soon reinvigorate their run down systems. Some 80 horses and mules had been slaughtered to supply the garrison with food, they say.

From all quarters we hear of the valiant service rendered by Rev. Mr. Gamewell, of the M.E. Mission, who was entrusted with the task of building the barricades for the protection of Legation Street. With the native Christian refugees as coolies working under him he raised strong barricades of sandbags, very high all round the place, winning the approbation of everybody, civilian and military alike.

To make sandbags everything that could be utilized for the purpose was resorted to. Even the splendid curtains of the Legations were not spared, and all the ladies worked nobly making the bags, on which the safety of all so much depended.

Yesterday it was fitting that a thanksgiving service should be held in Tientsin for deliverance granted to those in Peling and this place. It was arranged to take place at 9 o'clock in Victoria Park. A little before the hour a detachment at the Royal Artillery and Welsh Fusiliers marched into the park and took up a position at the west side facing the bandstand. A few minutes later an American band arrived, and while the audience gathered, played in magnificent style the "I2th Mass" and a medley of sacred tunes, among which were such well-known songs as "Shall we gather at the river," "Come ye disconsolate" and "Safe in the arms of Jesus." Seldom have the residents of this port listened to such music. By this time a great number of people had gathered. There were American and British soldiers and sailors, a few French and Russians, and officers of all nationalities. Most of those who had arrived from Peking were there, and all were pleased to see ex-Consul Bristowe, accompanied by Mr. Carles, H.B.M. Consul. At six punctually, Bishop Scott arrived, preceded by Mr. Mathews in full canonicals, bearing the Bishop's pastoral staff. They took up their position beside the band, and faced westward. The service commenced with the singing of "All people that on earth do dwell," and was heartily sung by the audience, led 
by one of the cornet-players of the band. After the church service had been gone through by the Bishop, assisted by Mr. Mathews, and special thanksgiving had been made, Rev. Mr. Lowrie of Paotingfu, with impressive eloquence, gave a resumé of our special causes for thanksgiving in connection with deliverances at Peling and Tientsin. He urged on all, while giving all due praise to noble defenders and deliverers, the necessity of acknowledging and thanking the great First Cause-the Almighty God. He likewise urged " in the name of Him who died for us all" that vows made to God when death was staring all in the face should not be forgotten.

Darkness was falling when this impressive service closed, and by request visitors left the park immediately, as with so many nationalities about a strict guard had to the kept lest the place should get damaged.

During the time Tientsin was invested by Gens. Sung and Ma, a Catholic Mission station half way to the capital, but off the main road, was besieged and sorely pressed by Boxers. Prior to this the Father in charge, a Frenchman, had gathered the converts around him and had thrown up entrenchments, which gave tolerable protection. Repeatedly the Boxers attacked, but were always successfully repulsed. These attacks, however, ran the little garrison very short of ammunition. By this time Gen. Ma had been driven from Tientsin and had made Yang-tsun his headquarters. Either Ma or Sung sent a peremptory message to the priest that the Catholics must all surrender or be utterly exterminated. What could the poor fellow do? He said he would surrender provided the natives with him were allowed to scatter among the villages. The Chinese agreed to this, and soon the foreign priest found himself in custody in Gen. Ma's camp. He had not been there lon's before the Allied Forces attacked the Chinese fortified camp. In the confusion that ensued he with his attendants managed to gret into the foreign lines without being shot and in a short time reached Tientsin, where he now is.

We have it on good authority that an American transport leaves for San Francisco on Sunday, and that most of the American Missionaries from Peking who are going home will sail on her. Several civilian black-sheep have of late the been spotted by the authorities in 'Tientsin and Peking attempting to do a little loot or blackmail "pidgin," without the license which seems to be the portion of those who have taken the "Queen's shilling." Some have been cautioned and some told to "get out." Could there be a greater contrast found than between the methods of warfare in South Africa and those of North China. Different people to deal with and the berrgars deserve it is the common argument. Eut the indiscriminate looting and worse which the soldiers of highly civilized powers have indulged in simply cannot be defendcel. Even the houses of our most reputed citizens have not been left alone by soldiers of the allied forces and it secms strange that officcrs, usually such gentlcmanly fellows, should allow their men such a free hand. The well behaved among the soldiers are in the majority, and for the sake of their good name the 
misbehaving minority should have a little more restraint put on them when the next military move takes place.

29th August.--It is rather interesting to notice the spirit of good comradeship that exists among the soldiers here. Especially is this so between the Americans, Japanese and British. Go where you will you will always find the American and British soldiers ready to sound the praises of the Japanese, whom they speak of as being the best men on the spot for "this job."

Another thing one is very pleased to notice, that is, that the native, of long-robed or coolie variety, are very much more respectful to foreigners than ever they have been around Tientsin. It is amusing to see how well the scholar and coolie alike gave the ordinary military salute to all foreigners they meet, especially in the neighbourhood of the native city, where for long "Yang-liuei-tsze" was the common greeting for all visitors.

Coolie commandeering still goes on, and every evening one sees large gangs of these going home from work, headed by one of their number bearing the flag of the the nation they are serving. Some of the Powers, however, do not get the credit of treating their men very well, so it is little wonder that numbers of them run away whenever they get the chance.

The road between Tientsin and Peking is considered safe now, so the refugees are able to come down with comparatively small escorts, but it is generally felt that unless the Boxer strongholds to the south of Tientsin are attacked and utterly destroyed, communication with the capital may be shortly rendered difficult. The high ripe kaoliang, still unreaped, along the river's bank affords splendid concealment for an army of snipers, who at any time may play havoc among the small and almost defenceless parties now going up and down.

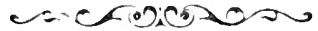




\title{
THE SIEGE OF PEKING.
}

\author{
By Rev. Gilbert Reid, D.D.
}

Peling, I $5_{\text {th }}$ August.-During the last two months the whole world has been aroused by events centering in Peking.. A month of real siege, and two months without chance to leave Peking: all this has formed an experience of solicitude, danger, hard work, much suffering and also many pleasant associations.

On the last day of MIay 459 officers and men of different nationalities came to Peking as our foreign guard. They proved our only defence from several thousand Chinese soldiers and Boxers whose Government was at war with the outside world.

By Sth June the Boxers had become dangerous in the south city of Peling, and were threatening the north or Manchu city. On June Ioth a relief force was reported as having left Tientsin, but as they occupied themselves in building the torn-up railway, they never came to relieve us. ITe relied on them reaching us sooner or later, but heard nothing of their real wherealouts till a message was received on 2nd August, announcing the fact that they had returned to Tientsin on 24th June, after tighting some battes and being in turn relieved by a parcy from Tientsin settlement. This retreat inspired the Chinese with jubilation and self-confidence, and rendered our position in Peking one of extreme peril. Having hạd a certain sanction from the Viceroy and the Tsungli Yamun to come to help protect us, they could probably have reached us with no resistance except from Boxers, if they had not made supreme the matter of repairing the railway and keeping communications open in their rear.

The tide of fury which swept up higher and higher to the capital from the Boxer movement alarmed us all by Sth June. The necessity to combine our forces and make preparations to ward ofi an attack was apparent. Outside the Legation section of the city, the main forcign population was missionary. The American missionaries consulted and decided to concentrate at the large and suitable quarters of the American Methodist Mission, just at the east end of Legation Street. The missionaries of the American Board at Tungchow, having just finished their annual meeting, were warned on the 7 th of June by the Taotai that no protection could be gruarantecd. As the Taotai 
was a progressive man and former director of the China Merchants, his word jwas taken as truth. A guard of American marines from Peking was asked for, but refused. Dr. Ament went instead and alone, taking a requisite number of carts to move the people. They left there at 3 on the morning of the 8 th, and reached here in safety.

The concentration of the missionaries at one place meant the desertion all of their houses and work. There was also a possibility of deserting the converts and attendants. Those, however, who could not find means of escape for themselves were allowed to go to the American Mission. The converts of the London Mission not being granted entrance to the British Legation, also went to the same rendezvous, and two or three of the English missionaries were there to help. There were 66 men, women and children, and over 600 natives. Twenty of the American guard were sent to give protection.

The Catholics were mostly gathered at the north Cathedral. Refugees came in from the city and country, until there were nearly 2,000 of them. There were a dozen Fathers, including Mgr. Favier, and about the same number of Sisters. Thirty of the French guard, and ten of the Italians were sent to protect them. There were several hundreds of the converts at the south, east and west cathedrals, and a French priest at each of the last two.

The members of the Customs service, including the instructors of the Tung IVun College, left their premises, which were away from the Legations, on I Ith June.

The desertion of so much property instigated the Boxers to attack, but there was no other course open, so long as the officials and the Throne seemed indisposed to suppress the growing disturbance. On I Ith June a secretary of the Japanese Legation was horribly murdered and mutilated by soldiers near the Railway Station. On the I 3 th, I4th and I 5 th of June the work of destruction went on by the hands of the Boxers, countenanced by the soldiers and some of the authorities. Pillage and fires ruined, these three days, as many as 13 churches, 7 hospitals, 7 schools and 33 houses. The foreign cemetery was desecrated, and bodies mutilated. Probably two French priests were massacred. On the $I 6$ th a still greater conflagration occurred in the south city, starting in a shop which sold foreign medicines and in a mill which had foreign machinery, and extending till it destroyed part of the tower and gate in the central part of the wall opposite the palace. Some 3,000 shops and houses and 26 banks were destroyed.

All this was the work of Boxers, while the soldiers did nothing to restrain them. Just in the midst of the excitement, the telegraphic communication was broken, and this, by previous arrangement, threw the responsibility for action on the Admirals at Tientsin. As we have learned since they threatened to take the Taku forts, and actually did so on I th June. This was a casus lelli, and was a wise move if the different countries had any decent preparations for protecting their people.

On June Igth the Tsungli Yamen handed passports to all the foreign Ministers, and gave them one day's limit to leave Peking. By 
an edict of June 2oth China declared war. Here then was the beginning of trouble for us. 'The Boxers were crowding the city, exulting in their prowess and invulnerability. The advisers of the EmpressDowager did not dare to offend the Boxers and were spurred on by a feeling of intense revenge against all foreigners. At the time they probably had no care for the foreign representatives and their families, but rather rejoiced that they too would be massacred, and that the whole country would be free from the last vestige of foreign barbarism. Folly and revenge ruled the government.

Early on Wednesday, 2oth June, excitement filled the bosom of every foreign resident in Peking. At first it was broached that carts would be provided to escort all to Tientsin. But the Yamen did nothing to provide conveyance, still less any escort. Baron von Ketteler, the German Minister, had written the night before to the Yamen, asking for audience with the two princes, Ching and Tuan, at 8 o'clock the next morning, and saying he would call at that hour. The Minister, with his secretary, M, Cordes, proceeded at the time mentioned in their sedan chairs on a mission of real friendliness, to try to warn China of the peril of the policy which had been entered upon and at least secure proper escort. They left their German guard behind to excite no needless animosity. On their way up the main street, perhaps twenty minutes from their Legation, a military officer with button and feather on his hat raised his rifle and aimed it directly at the Minister, killing him instantly. The secretary was just rising from his seat, when he was shot, but not fatally. He managed to get out of his chair and without further accident, but bleeding profusely, wended his way, in a round about course, to the AmericanMission. As soon as he saw a foreigner, he fainted away. German guards came to carry him to his Legation. The news quickly went from one to another. The thought of attempting a journey to Tientsin was given up.

The American missionaries were ordered to proceed to their Legation, and almost immediately to the British Legation as the international renderous. Only a few things could be taken, so much as personal servants could carry. The converts, including about 150 school girls, were permitted to fullow behind, though no one knew where they would be located or how they would be provided for. The houses, the university buildings, trunks and provisions were left behind, and the gates were closed. While the missionaries went on to the Legation, the thought occurred that a place could be provided for the converts. A few days before some 600 Catholic converts had been rescued from the south cathedral by two relief parties of foreign guards, and by a happy arrangement were stationed in a large open court of the palace of the hereditary prince, Prince Su, just to the east of the British Legation. The P'rotestant converts were temporarily established in the same place. 'The number of Catholic refurees afterwards grew to about I, $\$ 00$.

The one who had made the arrangement for the Catholics, and who was much respected by the Prince, was Rev Francis Huberty 
James. About ' 4 o'clock in the afternoon, Mr. James was passing along the north side of this nalace on his way to the British Legation. IVe saw him motioning with his hand; a shot was heard, and he disappeared. Our only conjecture is that he was killed. The murder of two eminent Europeans on the same day-China's seal to her declaration of war!

All the non-combatants were directed to establish themselves at the British Legation, which had been decided upon as final defence in case the other Legations would have to be forsaken. All through the afternoon of the 2oth the foreign community came passing in to the Legation, each building being set apart for the use of some one nationality or company. The siege had begun. No one knew the outcome.

The American missionaries were all tumbled down into the chapel, with no food, kitchen or beds, except the bedding brought with them. A few with their converts went back to the mission three times and carried away trunks and stores and bedding. The other foreigners that day gathered together all the stores they could from their own homes or from the two foreign shops. While no preparation had been made for a siege or defence, things got into shape in a most remarkable manner.

The line of defence was about I,000 yards east and west, from the Russian and American Legations at the west to the Italian Legation at the east, and some 600 yards north and south from the Austrian Legation at north-east and British Legation at the north-west to the city wall at the south. Between were the French, German, Japanese, and Spanish Legations, the quarters of the Customs, the Hotel of Peking, the Club, Kierulf's store, lmbeck's store, Hongkong Bank, house of Peking Syndicate, the palace of Prince Su, and several native houses and shops. The Germans and Americans also occupied positions on the wall. This was the parallelogram of international defence.

At the British Legation were over 400 foreigners (not including the marines) and over 350 Chinese, men, women and children. About 2,300 Chinese were congregated at the palace of Prince Su, all of which was turned over to their use the second day of the siege.

The guns with our force were Colt's automatic with the Americans, the Nordenfeld with the British, a maxim gun with the Austrians, and a one-pounder with the Italians. On 7 th July was utilised what was termed the International Gun. It was an old English gun of ' 60 found that day in a Chinese shop by a Chinaman. The shells fitted to this gun were Russian, the Russians having brought shells but no gun. It was placed on an Italian earriage and had an American gunner.

Hardly had the cosmopolitan company assembled at the British Legation, when not only the food supply became an important question, but the whole matter of fortification was seen to have been left almost neglected. Less had been cone than at the American Methodist 
Mission, and yet there was the possibility of needing the Legations as a place of defence. Rev. Mr. Gamewell of that Mission, who had shown skill in making fortifications, was chosen by Sir Claude Macdonald as chief of fortifications. Day after day and many nights, he toiled, until at the end we began to feel ourselves quite secure.

A general committee was also appointed, Rev. Mr. Tewksbury (Chairman), and Rev. Mr. Hobart, American; Mr. Cockburn and Mr. Bredon, British; MIr. Popoff, Russian; Mr Morisse, French ; and Mr. Kruger, German. Other committees were formed to assist the military.

The men among the refugees proved to be of incalculable service in the manual work and the work of fortifying. Though many Europeans cared nothing about saving the converts, they were quick enough to accept the indispensable help which the Chinese rendered.

Captains Strouts and TVray, of the TVeihaiwei force, and Capt. Halliday, of H.B.M. ship Orlando, all of the Marine Light Infantry, were the British officers in command; Lieut. Baron von Raden of the Navy was in charge of the Russians; Capts. Meyers and Hall, Marine officers, of the Americans; Lieut. Darcy, Naval, of the French; Capt. Thomann von Montalmar and Lieut. Winterhalder, both Naval, of the Austrians; Lieut. Paolini, Naval, of the Italians; Lieut. Count Sonden, Marine, of the Germans; and Lieut.-Col. Shiba Military Attaché, Capt. Morita and Capt. Ando, of the Army, and Lieut. Hara, of the Marines, the officers for Japan. In an informal way, and as chief host, $\mathrm{Si}$ - Claude Macdonald, formerly Major in the Army, was commander-in-chief, though Col. Shiba or Capt. von Montalmar was senior of the active officers.

The day after our siege began, we had our first sign of weakness. The Austrian guard was stationed at the north-east point of defence, with chances of being fired upon from north, east and west. After a little skirmish they withdrew from their main and outermost barricarle to a barricade further south, just north of the French Legation. This left the Austrian Legation and the Custom House, with all of Sir Robert Hart's valuable books and papers, exposed to the coming wrath of the enemy.

On 22nd June came a second and more serious retreat. Through a misunderstanding that the Americans were going to leave their Legation, the Austrian commander, as senior, directed his men and the other guards to fall back on the British Lcgation. Thus Austrians, French, Italians, Germans and Japanese came rushing into the British Legation from the east. and on this move the Americans left their position on the wall and their Legation and along with the Russians came rushing in from the west. Each officer soon detected the mistalie. All realized how weak we would be placed, if nothing was defended except the British Legation. Sir Claucle Macdonald especially saw the importance of holding the Palace of Prince Su as greather security to his Legation. In a few moments there was a rush back to positions, and with more enthusiasm than before. The 
Austrians, however, did not hold the barricade north of the French Legation, where they had just been, but joined the French in making the French Legation the limit. The Italians likewise did not return to the barricade in front of their Legation and just east of the French Legation, but took up a new position in the garden of the palace grounds of Prince Su. The Japanese also took up positions in these grounds, and with the Italians made protection on the east to the British Legation. The Germans and Americans reoccupied positions at their Legations and on the city wall. The property of the Austrian and Italian Legations, like the Belgian and Netherlands, was left exposed to the enemy. The day was serious in casualties2 killed, I dying from wounds, and 5 others being wounded.

The same day came the first experience with the enemy's plan to burn us out. The attack was made on the British Legation. About five in the afternoon dense smoke and flames suddenly arose close to the Legation wall, on the wall, and behind two of the Legation houses. The arrangements for fire had been thought of, but not fully made. Where were the wells? where were water buckets? Where was a water pump? Where was a ladder, axes, and other utensils? These were the questions as the excited throng ran to and fro trying to find out who was head. In brief, under the leadership of Mr. Tweed, of the H. K. Bank, and Mr. Tewksbury, the wood of the building of the servants' quarters adjoining the wail was torn down, water was poured on, and the flames destroyed the building outside our defence without doing harm to ourselves. The large water supply of the British Legation proved its finess for general headquarters.

Again, 23 rd June, came an attack from fire, which proved more disastrous than the Chinese themselves could possibly have wished. Vell suppied with kerosene, the Chinese started a fire north of the British Legation and near the north stables and the Minister's quarters in one of the buildings of the Hanlin Yuen. The fire was prevented from extending inside our wall though a wind was blowing from the north. An opening was made through the wall that separated the Hanlin and the Legation, and Captain Poole conducted a party through to drive away the Chinese, and after a few shots was successful. In the afternoon of the same day the Chinese started another fire in one of the largest buildings of the Hanlin. As the flames, thick and black, rose upwards the danger seemed great, but as the wind had shifted and blew more to the north, it was decided to let the fire do the work of destruction with no restraint from us. Smaller buildings near the Legation wall were torn down for better security, and the whole Hanlin gradually became our northernmost point of defence, with strong barricades. The library of the Hanlin was destroyed, except a few books which we ourselves saved. Here incleed was a most remarkable sight-the Boxers out of spite against the foreigners bringing ruin to the leading representation of official Confucianism under the presidency of the most noted foreign hater, Hsü Tung. The Hanlin, exponent of conservatism, and the Customs 
property and records, exponent of progress, were alike destroyed by the same fire.

One other attempt was made to set fire to the British Legation on $24^{\text {th }}$ June, but, being unsuccessful, the Chinese tried elsewhere and with consiclerable success. The first one was also on 24 th June made against the Japanese position in Prince Sus grounds. That day or thereafter nearly all the buildings were gradually destroyed. The Japanese and native converts had less facility for resisting. The enemy thereby manared not only to destroy this palace, which was a sccondary matter, but to advance their own barricades and drive back the defences of both Japanese and Italians. Our new line of defence was made stronger than any we had before. The converts were moved into other buildings.

Fires had a large part in ruining a part of the French Legation. Outside our line of defences the Austrian, Italian, Belgian and Dutch Legations, the Russian Bank and one foreign store were destroyed by fire. Each day from June $13^{\text {th }}$ to June $29^{\text {th }}$ there were seen fires somewhere in the city.

From the first clay there was rifle firing, which grew into a regular fusilade by $25^{\text {th }}$ June. That night and five consecutive nights the fusilades were hideous in noise, if not specially dangerous. It seemed as if an assault was really to be made for our complete annihilation. On the night of the 29th it began at 10 o'clock and continued without intermission until 4 o'clock, the shots coming into the British Legation from all sides, and with the sound of the firing, the echoes, and the explosion of bunches of firecrackers, there was a torrent of rain with flashes of lightning. The noise and commotion were hellish.

The rifle firing was mostly at night, but the injury inflicted was greater in the day. There was some sharp-shooting, showing that under proper drill the Chincse could make good soldiers. Many of those wounded were from stray shots or from carelessness. At night the main thing for our men to do was to lie low and save their ammunition.

Firing from guns began on $23 \mathrm{rd}$ June, and became real cannonading by the 2 Sth. There was a large three-inch gun at the gate to the west of the American position; another at the gate to the cast of the Germon position; a large Krupp gun north of Princè Su's palace and French l.egation: a smaller gun for a few days west of the British L.egation; and probably three guns in the Imperial city north of the British Legation. In proportion to the number of shells or cannon balls fired the harm done was very slight. From 5th July to $13^{\text {th }}$ July the number of shots fired as actually counted was 2,614. The total number could not have been less than 4,000. Bomb-shell shelters were prepared in the British Legation, but never used. The greatest harm to buildings was on the French and German Legations and the Hotel de Peking. Only If out of iso persons were killed or wounderl by shells.

Our sorties all proved worse than failures. The first on 24 th 
Junc, under Captain Halliday, was made from the British Legation to capture the gun which fired from the west. The gun was not reached, and Captain Halliday was so severely wounded that until the troops came he was unfit for service.

The second sortie was made on ist July to capture the large sun to the north. There were two routes taken from the grounds of l'rince Su. One route was taken by a few Italians and British under the Italian commander, Lieut. Paolini. The second was taken by the Japanese under Capt. Ando. The former course proved a bad one, leading right up against a Chinese barricade. At once the trap was sprung. Two Italian marines were killed, the Italian commander, two British marines, and a student of the British Legation, Mr. IV. C. Townsend, were wounded. In the Japanese party one was kilied.

A third sortie to capture the same gun was made on 6th july by the Japanese under Capt. Ando. The gun was not captured, but just when it was reached Capt. Ando was killed and two Japanese were wounded.

The guns and most of the rifles were fired by Chinese soldiers, as the regimentals proved to us when they were captured. Still, as the edicts early in the war slow, the aid of Boxers was called in by the Throne. On 24th June the edict was issued appointing Prince Chuang, one of the hereditary princes like Prince Su, in supreme command of the Boxers. Kang Yi, Grand Secretary and Minister of the Cabinet; Ting Nien, Sub-Governor of Peking; and Duke Lan, also Sub-Governor, cousin of the Emperor, and uncle to the heirapparent, were appointed to command second to Prince Chuang. The same day 7,200 piculs of rice were ordered to be given by the Board of Revenue to Kang Yi for distribution to the Boxers. All this was done the morning after the Hanlin was burned in order to better attack foreigners. On the following day recognition was continued by the Empress-Dowager giving 100,000 taels, not only to the two divisions of Manchu troops, but to the Boxers. In those days the Empress-Dowager handed herself over completely to the Boxers, and harl confidence that her war would be waged successfully. She even exhorted the Imperial nobles not to be behind the Boxers in courage and loyalty. Then and even afterwards the Christian adherents were condemned, warned or insulted.

Also on $25^{\text {th }}$ June, in the afternoon, a board with Chinese characters was hung up on the bridge north of the British Legation by a man carrying a white flag. It gave an Imperial message that there would be no firing and that a despatch awaited us at the bridge. Our messenger started, but when near the place saw soldiers raising their rifles as if to fire. In any case, judging from the circumstances, there must have been only trickery and treachery. The Chinese were not yet in a state of humble supplication.

On 3oth June and Ist July came a serious encounter with the Chinese on the part of the Germans. On the former lay the Chinese placed a gun east of the German position on the wall, and began to put up a new barricade nearer the Germans. The Germans with a 
weak barricade and only rifles, but with plenty of pluck, began to fire. The Chinese from a sheltered position answered hotly. The result was a bad one for the Germans, the worst of the whole siege. Two were killed instantly; two were wounded, who soon died; and four others were wounded, but recovered. The same day three others were wounded, and one died from wounds.

Early on the Ist of July the Germans retired from their position on the city wall to their Legation. The Americans further to the west saw their German comrades rushing down the ramp, and Capt. Hall, realizing that his men would now be exposed to firc from both east and west, and in fact were already being fiercely shelled, gave orders to his men to retire to their Legation from the other ramp. The Minister and Secretary, both participants in the Civil IVar, saw clearly that this retreat would endanger their Legation, and that, if the guns should be placed nearer, they would endanger the general defence at the British Legation. The British Minister and Capt. Myers were consulted, and the order was given to return to the wall and hold it at all hazards. All of us were willing to assist, and so spent the Sunday morning in making sand bags, filling them and transferring them to the American Legation. The barricade between the Legration and the wall needed to be strengthened; defences needed to be provided up the side of the ramp; and stronger barricades needed to be made on the wall to protect from the east and west. The converts were urged on in face of danger, and several were injured. Work was postponed until night, and then carried on through the following day. Parts of the work were under fire from sometimes four directions, but were performed with caution and so with security.

The Chinese were also busy in barricading, and having a larger number of men, could accomplish more. They began a new barricade 30 yards west and extended it cross-wise into a bastion almost up to the American barricade. The two were so near that bricks were thrown by the Chinese upon the Americans. A plan was formed to make an assault upon the Chinese that night. 'The aid of British and Russians was given, and about 2 o'clock on the morning of the 3 rd of July the advance was made. Capt. Myers led the British and Americans by the south end to the bastion and inside the barricade of the Chinese. As he passed through, he struck his leg against a spear, which inflicted a painful wound. The Chinese were taken by surprise and fled clear down to their second barricade. Two of the American marines were killed. The Russians took the direct course along the north edge of the wall up to the Chinese barricade which they afterwards held. One Russian was wounded. By the combined attack some 40 of the Chinese were killed and some rifles and ammunition captured. New and very strong barricades were built making the position almost impregnable.

The French and Austrians at the French Legation had more and more a dangerous position to hokl. Shells, fres, rifle shots, and mine explosions all fell to their lot. On the i2th of July the Chinese were 
discovered making a mine into the Legation from the east. The Chinese did only a little firing, but wounded four of the French, one, M. Gruintgens, was a civilian who had studied Chinese at the College de France, and had come to China early in the year as interpreter on the Lu-Han Railway. He was wounded severely in the throat, and after a day of suffering, endured in great calmness, he passed away.

The I 3 th of July was the day of most severe assault, and the only real forward move from the Chinese. About dusk the mine which had been dug exploded, burying three in the ruins, one of whom was Dr. von Rosthorn, Chargé d'Affaires for Austria. In a few minutes a second explosion came, which blew Dr. von Rosthorn out of the ruins, having only a slight bruise. Several of the Chinese were also buried in the ruins. The explosion destroyed part of two buildings. Fires were started which destroyed the main building of the Minister. The Chinese at the same time kept up a heavy firing. The French and Austrians, though forced to give up over half of the Legation and occupy only the western part, maintained a steady fire. Besides the two buried in the ruins, one French marine was killed, the French commander, Lieut. D'Arcy, two French marines and one Austrian were wounded. The Chinese are reported to have lost over 200.

All through this uproar, the Chinese began an attack on the German Legation. They entered the Club adjoining, when the Germans rushed forth upon them, killing some and driving the rest back to the wall. Three Germans were wounded.

Other Chinese passed beyond the German Legation at the foot of the city wall towards the west. They set fire to the house of the Peking Syndicate. The Americans from behind their brrricade saw the move, fired and drove the enemy back to their own barricade.

There must have been an unusually large number making this attack. The bugles blew, and the turmoil kept up for nearly two hours. All the eastern line of defence was under tremendous fire, but, considering the numbers, our men made a gallant fight and splendid resistance, enough to prevent a similar attempt. While our combined forces had to give up a position on the wall at the German Legation, a position in the French Legation and the grounds of Prince $\mathrm{Su}$, we advanced by occupying a stronger and larger position on the wall at the American Legation, a position in the Hanlin and latterly a Mongol market west of the British Legation, where the Chinese at the beginning had done their heaviest firing.

Of those who amid the hnndreds of shells were killed through their explosion, we mention Captain Thomann von Montalmar, Austrian officer, who after accompanying the guard to Peking was detained from leaving and was therefore senior of the officers, unless we except Col. Shiba; Mr. H. Warren, a student of the British Legation; and Mr. Edward Wagner, son of a former French ConsulGeneral in Shanghai, a member of the Customs service, and acting as Postal Secretary.

The rifle firing, though slack in the day-time, had its serious effects. Our own men, after the first few days, seldom shot except to 
hit. The Chinese sometimes aimed, but more often fired into walls or space. Some of our number were hit in the British Legation from shots fired in the palaces of Prince Su, and others were hit in the American Legation from shots on the city wall. Several who were directly attaclied have been mentioned above. The surgeon with the American detachment, Dr. Lippett, was accidentally shot, while standing in the doorway of the American Legation. His wound was among the most serious, but after 40 days he is now slowly recovering. Mr. D. Oliphant, a student of the British Legation, was shot while cutting down a tree in the Hanlin, and died in a few minutes. His brother, Mr. N. Oliphant, of the Imperial Bank, was injured while putting up a barricade for the Japanese. The "Times" correspondent, Dr. Morrison, was wounded while passing near a dangerous place in Prince Su's grounds. At the same time Capt. Strouts was more seriously wounded, and died in about two hours. A secretary of the Japanese Legation, Mr. Narahara, after nearly two weeks of suffering in the hospital from a wound, died through blood-poisoning. Among the American civilians I was the only one to be shot, probably from a jingal, but largely through carelessness as to where I was going.

The British detachment numbered S2. Of these three were killed and sixteen wounded. Of the civilians two were killed and seven wounded. The Russians numbered 75, with 9 Cossacks. Of these four were liilled and I4 wounded, and two died from sickness. Of their civilians one was killed and one was wounded. The Americans numbered 63. Of these seven were killed and ten wounded. One civilian only was wounded. The Germans numbercd 50, of whom eleven were killed and sixteen wounded. The French (not including 30 at the North Cathedral), numbered 45, of whom eleven were killed and twenty-one wounded. Of their civilians three were killed and four wounded. The Ausirians numbered 35, of whom four were killed and ten wounded. One civilian, the Chargé, was wounded. The Italians (not including 10 at the North Cathedral) numbered $3 \mathrm{I}$, of whom seven were killed and twelve wounded. The Japanese detachment numbered 29, of whom five were killed and thirteen wounded. Of their civilians they lost the most of any country, five killed and five wounded. The total, killed and died, 54 of the regulars and I I of the civilians; wounded, I I 3 of the regulars and 20 civilians. Of those killed 5 were officers and of those wounded 9 were officers.

The converts, who were daily pressed into duty, ofientime in places of danger, had a list of 9 killed and 12 wounded.

Of the civilians killed or wounded nearly all beionged to a temporary voluntecr force, most of whom carried arms and the rest did patrol duty. The largest force was at the British Legation, consisting of men from all occupations at all represented among the besieged. There were 92 in all, made up of 46 British, I 5 French, I 3 Russians, 4 Germans, 3 Amcricans, 3 Italian, 3 Beggian, 2 Dutch, 2 Portuguese, and I Austrian.

Capt. Poole, formerly of the Indian army service, and now in the 
home service, was chief. An ex-army officer, Capt. Percy-Smith, being on a visit to Peking, rendered valuable assistance not only for the voluntecrs but the regulars. Lieut. von Strauch of the German army, and now connected with the Customs service, was also in charge.

At the French Legation was a second volunteer band of 19,12 of whom were French, 3 Belgian, 2 Austrian, I Italian and I Swiss. Dr. von Rosthorn was one of the number. His brave wife remained at the French Legation until there were no suitable quarters, and then she moved to the German Legation, being the only lady remaining away from the British Legation except two ladies at the Hotel.

The Japanese volunteer force consisted of 26 Japanese, proportionably the largest of any country, After a while they added on 26 Chinese Christians, 4 being Catholics and 12 Protestants.

With the Italian detachment was the accomplished Secretary of the Italian Legation, Don L. Caetani, son of a previous Minister of Foreign Affairs at Rome.

The members of the German Legation remained at their post to assist their soldiers. A Dutchman, Mr. van Zuylen, was with them. At the American Legation were Mr. Squiers, and Mr. Cheshire, Secretaries, while Minister Conger spent the longer part of this time there. Mr. Pethick, American, and Mr. van Duysbero; of the Netherlands Legation, did splendid service.

Thus less than 600, which gradually diminished to 400 , defended one wide circuit against a foe which at one time must have been as many as 10,000 . The foe for nearly a month kept up a severe attack in one form or another, and had no compunctions, because innocent women and children, high representatives of Foreign Powers, or old friends in the pay of the Chinese Government, were the objects of their wrath. It was all done with the consent of the Chinese Government.

Beside the military part of the siege, including the work of fortifications, a serious problem was that of providing a supply of food not only for nearly 1,000 foreigners, but for over 2,500 Chinese. Little thought had been given this subject before we were suddlenly in the midst of a forced imprisonment. The members of the British Legation staff had of course a supply of canned goods, but each group had to form plans for itsclf, which resulted in greater comfort for some than for others. The purchase of vegetables was no longer possible. As to meat there were a few sheep, sufficient for the sick, wounded, and the favoured only a few weeks. There were fortunately a good number of horses and mules in the Legation, or brought in the first day. Thus our meat supply kept up until the end. As to flour, there were only a few bags of white flour for the whole company a week and more. Fortunately again there were native shops within our line of defence, and therein there was an abundant store of rice, coarse wheat, and still coarser grain. A mill was started and kept a-going, grinding brown flour, both nutritious and really palatable. A public bakery was also started. Coffee, tea and sugar lasted, and butter for 
occasional use. There were wines for those who wanted them, but in moderation only.

The main anxiety was concerning the little children. It was difficult to keep a supply of condensed milk, for the grown-up were disinclined at the outest to forego its use. In various ways the children were cared for. There were several cases of sickness among them. The only deaths from sickness were of children. There were five of these little once called away to their happier home, one child of Mos. Kruger, two of Mrs. Imbeck, one of Mrs. Inglis, and one of Mrs. Book. The sickness among the Chinese, and especially the children, was much greater, owing to poorer food and accommodation.

The Chinese authorities sent us some melons and cucumbers, and Jung Luh sent a few bags of rice and flour, which might suffice for one day's rations, if used sparingly. In any case the home Governments were informed that we, or rather our Ministers, were both provided with food and protected by the Chinese government. For a few days, eggs were sold to us but beyond this there was no market. Just a few days before our troops were to arrive the Ministers asked that a market be allowed. The Yamen gave permission, but no provisions came.

In a siege such as we have described medical work and a hospital were most essential and proved a blessing which at least 120 persons will appreciate through life. The physician to the British Legation, Dr. Poole, brother of Capt. Poole, was appointed chief by this Minister. The German surgeon, Dr. Velde, was his associate. The sanitary part of the Lcgation was under the special charge of Dr. Dudgeon, an old resident of Peking, and two American missionaries, Drs. Inglis and Ingram. After Dr. Lippet was wounded, Dr. Lowry, another medical missionary, was stationed at the American Legation. The French physician, Dr. Matignon, remained at the French Legation. A Japanese surgeon, Dr. Nakagawa, was stationed with the Japanese detachment. In the hospital was a splendid corps of assistants and nurses. Chief in charge was Nurse Lambert of the Church of England mission. Others were Dr. Saville of the London Mission, Drs. Gloss, Leonard, Mackey and Martin of American missions, the sickbed steward of H.P.M. ship Orlando, Mr. Tuller, an Italian and an American steward, Deaconess Jessie Ransome of the Church of England, two or three sisters from the Catholic Mission, several Russian ladies, and Mrs. Woodward, an American lady visiting at the American Minister's. We were favoured in having such a number of competent, well trained, kind and accomplished persons to care for the suffering and console the dying.

It has been a matter of surprise and gratitude that though thousands of shells and bullets came whizzing into the Lcgation, not one of the ladics and children met any injury, until the very last day of the siege, when a French lady was wounded. This, too, was in spite of the exposure that they underwent both by day and by night. These, not the Boxers, were the real invulnerables.

The Irotestant converts who were wounded or were sick were 
under the charge of Dr. Tsao, a member of the American Methodist Mission, and a graduate of the Medical College in New York. The Catholic converts had the services of Dr. Talayrac, a Belgian physician on the Luhan Railway. There were two separate hospitals, the one for the Catholics in the Russian Legation and one for the Protestants in rooms adjoining the British Legation. The Catholic sisters and several of the missionary ladies rendered what help they could amid very unfavourable circumstances.

Our siege was a real one, as communication was out off both by the diplomats with their governments, and by any of us with our friends. Prior to the siege the last message came from Tientsin under date of June $I 7$ th. We sent messengers to the relief force and to Tientsin, but some were never away, and others returned emptyhanded. Not until July I6th did we have any word, and then it was a telegram to Minister Conger from the State Department, transmitted through the Chinese Minister at Washington and the 'Tsungli Yamên, asking for information, but giving none. The first information came July ISth, from the Japanese Consul at Tientsin, telling us of the capture of the Taku Forts and Tientsin, and of the intended departure of foreign troops about July 2oth (but delayed till first of August). 'Two or three other messages came, and the Tsungli Yamên, having entered on correspondence with the Ministers, especially with Sir Claude Macdonald, now and then transmitted some telegrams with a little information. In the main we had two months of exclusion from the outside world. We were even kept in ignorance of Peling outside our defences. The north cathedral was beyond our help and knowledge.

For the burial of the dead an international cemetery was gradually arranged at the south end of the British Legation. The Americans were laid to rest in the Russian Legation side by side with the Russians. Japanese and Chinese converts who died found a restingplace in a court just south of the grounds of Prince Su. Most of the French and Germans were buried in their own Legations.

An informal truce began on July i 7 th, when two Chinese came in from the enemy's ranks, suggesting that we stop firing. The Chinese on their side ceased firing. On the ISth an edict was issued commanding protection and compensation for missionaries and merchants. There seemed to be less inclination to prosecute the war, and quite naturally so, as 'Tientsin came under foreign control on the I 4 th.

Later on occasional firing began again, and a more vigorous attack by August 4th. The edicts again showed defiance, by allowing no mercy to Chinese Christians fighting for their defence, by the decapitation of two progressive officials, Hsu Ching Ching and Yuan Chang, and by the favour extended to the foreign hater, Li Ping Heng. At the same time Li Hungchang was given full powers to negotiate peace with Foreign Governments. On the nights of 9th, Ioth and I Ith of August, there were still heavier attacks.

On the I 2 th the Tsung-li Yamên sent to Sir Claudle Macdonald a note asking that an appointment be made at 4 o'clock of the same 
day to consider their proposals of peace. During the day there had been several sharp attacks made by the enemy-the followers of the Princes and Nlinisters of the Yamên. Sir Claude, actingr for his colleagues, designated I I o'clock of the following day. 'There was no demand on the part of our Ministers for complete surrender before conferring. There was cven no demand for an armistice. From $50^{\text {'clock }}$ in the afternoon till $50^{\circ}$ clock on the morning of the $13^{\text {th }}$ there was a continuous fusilade, lasting longer and sharper than any that had occurred during the whole siege. During the I th a French officer and one marine were killed, and one German, one Austrian and one Russian were wounded. All this made ridiculous any thought of peace. Furthermore on the 13 th the Tsung-li Yamen administered a rebuff to foreign diplemacy by writing back that they could not confer from press of business, and adding that we had broken the agreement in opening fire and killing over twenty of their officers and men. Later they wrote that they had ordered their men not to fire on us and would court-martial any who disobeyed. That night we had the sharpest general attack and after mirlnight we heard the first glad sound of relief from beyond the city wall to the east. In the afternoon of the I $4^{\text {th }}$ came the first appearance of the relief force at the British Legation. They were the Sikhs, who were checred lustily by men and women of every nationality.

A splendid spectacle was the harmony of our international company from Europe, Asia, and America, toiling and suffering together, all creeds and classes of men, eager to make impregnable our common home. Never before was there such an international company besieged in war.

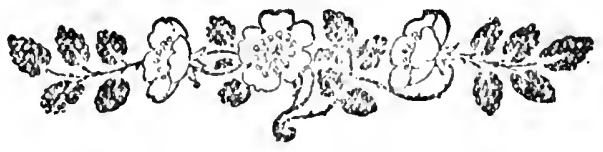




\section{THE TAKING AND OCCUPATION OF PEKING.}

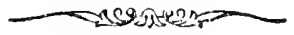

The following is the report of Captain J. Poyce-Kup, of Messrs Jardine, Matheson and Co., who was on General Gaselee's staff, to the head office of his firm at Shanghai :-

On arrival at Tungchow (I2th August) it was arranged that the allied forces should each send out a strong reconiaissance on the morning of the I $3^{\text {th }}$ to advance to within about sirs mites of Peking, and that on the I 4 th the main bodies should arivance and concentrate, the general attack on Peking to be on the I 5 th. About 2 a.m. on the 14th, however, we were awakened at Tungehow by heavy cannonading in the direction of Peking, when the whole of the British force received immediate orders to march, and on joining our advance post about 9 a.m., near Peking (about 6 miles from the walls), we found that the Russians and Japanese had commenced their attack that morning, which accounted for the fring we had heard.

The British having been given the extreme left, as the Climese were reported to be strongly entrenched at the S.E. corner of Peking, and as heavy opposition was thus to be expected there, our allies hoped that we would not be in Peking until long after they were. The contrary, however, was the result, as owing to the precipitate attack of the Russians and Japanese $\mathrm{N}$. of the canal the Chinese, being under the impression that the main attack was there, withdrew their troops from the Chinese City to reinforce those defending the Tartar City and when we sudkenly appeared (having been hidden by the dense and high crops) before the E. Gate of the Chinese City we found it practically undefended and gave the Chinese no time to get their men back, but marched straight into the Chinese City which seemed almost deserted. I had, however, with the assistance of some Chinese still left in the streets, but little difficulty in guiding our forces to the sluice gate in the Southern Wall of the Tartar city just opposite to the British Legation, our advance on which was covered by a party of Legation Guards who held that portion of the wall, and although we were met by an enfilading fire from the Clinese at the next gate on the $\mathrm{E}$. ( $\mathrm{Ha}$ Ta Men) we crossed the moat without difficulty and entered the Legation at about 2.30 p.m., some 2 hours 
before anyone else arrived, the Americans being the next in, and the Japanese and Russians a long time afterwards. Our march from the further side of Tungechow of more than 15 miles in a broiling sun with the attack on Peking immediately following was no mean feat of endurance, although the actual fighting was but slight.

The appearance of the Legation was anything but what we had expected, as everyone looked well and all (especially the ladies) had donned their best bib and tucker in honour of our arrival. If it had not been for the incessant and deafening fusilade kept up by the Chinese (of which no one took the slightest notice, by the way, they all being so used to it) we might have thought ourselves in the midst of a huge garden party!

Since the taking of Peking matters seem to be at a deadlock, the Imperial party, high officials and army having all apparently melted into thin air. The army, I hear, is concentrated to the S. WV. near Paoting-fu, and Prince Ching has just been prevailed upon to return to the metropolis under a Japanese and British cavalry escort, although I have an idea that the Russians, who have taken possession of the Summer Palace without any reference to their allies, may have entertained His Highness en route.

Ever since the battle of Yangtsun, after which the Russians refused to advance unless the order of march was Japanese, Russians, Americans, British (the French electing to remain at Yangtsun, whence they followed on, however, as soon as they saw they could get through with safety), I have had a suspicion that the Japanese have come to some understanding with the Russians, as otherwise these latter could not have played the high-handed game they have all through, as the British, Americans and Japanese would have been too much for them, and since our arrival here I have seen nothing to disabuse my mind of this idea. The Japanese appear sometimes amazed at the overbearing attitude of the Russians, but I think this is more for effect than anything else.

The triumphal march through the Forbidden City took place on the i 7 th August, and scemed rather a ridiculous procedure. Detackments of every regiment and branch of service in Peling formed part of the procession, headed by their bands (in the cases of those who had them), but somehow the Russians managed to get about 1,500 to 2,000 men into their part of the procession. After the march through officers were allowed to return and inspect the Palace, when many availed themselves of the opportunity to do a little looting-the Russians again being foremost here. Although most found their capacious trouser pockets sufficient to contain the few "souvenirs" (as they called them) they took, one was seen going off with a sack load. 'The Germans were not far behind the Russians at this, and I do not know how the Americans and Japanese behaved, but the British I can vouch for took absolutely nothing.

We have just made a move in the right direction in offsetting the Russian Railway aggressions by taling charge of Feng Tai and Lu Kau Chiao (including Marco Polo's Bridge there-the highway 
to the rest of China), at both of which places we have established military posts. The one at the latter place reports being in touch with the enemy at a distance of about 5 miles. The Russians have the Peling Station ( Ma Chia $\mathrm{Pu}$ ) and a post about 2 miles down the line on which they pretend to be working-their idea seems to be to procrastinate all railway work as much as possible, and they are said to be making very slow progress with the line upwards from Tientsin. The big bridge at Yangtsun is but little damaged, as also is the bridge over the Hun Ho at Lu Kau Chiao.

The military question of the day seems to be if (as apparently is the case ) a large allied army is to be kept here during the winter, how are the necessary supplies to be obtained? The British force would appear fairly secure in the above respect, having stores in hand here and the best transport (except the Japanese) between this and Tientsin, but it is not so with our allies, notably the French, who have been leading a very hand-to-mouth existence, and the Germans do not appear to be well furnished with stores or transport either. As far as I can see the British plan is to withdraw as many men as possible before the winter, but every one else seems only anxious to get as many men in here as possible.

To return to the march up. The battle of Peitsang was won by the Japanese, that of Yangtsun by the British, since when the Japanese took the lead (almost at the double) and kept the Chinese on the move right up to Peking, rushing them through Ho-hei-wu, Changchiawan and Tungchow, after which their men were so clone up that they slept by their guns, the wonder being they had kept up so long. The rest of us hardly fired a shot after leaving Yang-tsun until we reached Peling, the biggest engagement on the way being the bombardment of Changchiawan by the Japanese, which lasted about a couple of hours. IVe suffered considerably from the heat after leaving Yangtsun, the Americans especially feeling the sun, owing a great deal, I fancy, to the want of protection afforded by the small felt hat they wear, and falling out in great numbers. Peling has been divided up for purpose of police and garrison as per the rough sketch on next page, and the districts under both British and Japanesc control are gradually assuming something of their normal aspect. The French burn and shoot right and left, however, and the Germans, when asked if they had taken over the section reserved for them and temporarily held by the Russians, replied-"Oh, yes; we shot about 70 yesterday." 


\title{
THE CATHEDRAL SIEGE IN PEKING.
}

\author{
[By the Rev. Gilbert Reid, D.D.]
}

If the siege of Peking is a story of marvellous preservation, the story of the siege of the North Cathedral is a story still more marvellous.

The Roman Catholics in Peking had four large places of worship, north, east, west and south, according to the location in the city. The north one was properly the Cathedral, as the Bishop resided in quarters connected with it.

During the days just prior to the siege there were left just two missionary headquarters free from attack, outrage, massacie, conflagration and destruction at the hands of the Boxers, namely, the North Cathedral amongst the Catholics, and the American Methodist Mission, with its Peking University, among the Protestants. The Protestant headquarters were abandoned when the British Leganion was made the general international headquarters on June 2oth, and were soon totally destroyed, leaving only one Protestant place of worship in the whole city, that of the Chnrch of England in the British Legation.

Of the Roman Catholic edifices, the South Church, or, as it is generally called, the Portuguese Cathedral, was the oldest Christian edifice in China. Next in order came the West, then the East, and lasty the North. 'The last two were built by the architectural and artistic skill of the same man, the present Bishop of the Diocese, Monsignor Favier.

The erection of the North Cathedral was a part of an interesting political diplomacy. From the year IS64 there had been a North Cathedral, the only Christain edifice within the Imperial City. Of more note, it adjoined the Imperial Palace, and so closely that one from the summit of the Cathedral could look over into the palace grounds. This was an offence and an aggravation to the Throne, and especially for the present Empress-Dowager. She had a high wall built to "shield her from the baleful effects of a foreign religion." This did not suffice. She made different overtures to the French Minister to either have the edifice removed or to make an exchange for another location. Such an exchange was effected in the year i 886 . A large site of twenty acres was given, situated also inside the 
Imperial City, and with a pecuniary recompense of over $£ 75,000$, a new North Cathedral was erected. Connected with the Cathedral proper were buildings arranged around open squares for the Bishop and priests, for a printing establishment, for a foundling hospital and a dispensary.

When the Boxers began their attack, they succeeded on successive days, June $13^{\text {th, }}$ I $4_{\text {th }}$ and 15 th, in burning to the ground the Eastern, Southern and VVestern Churches. The North Cathedral, situated nearly an hour's distance from the Lcgations, entered on siege by itself. For two months there was no communication between the two places of defence in the same city.

There were congregated within the North Cathedral thirty French officers and marines, ten Italians, thirteen Firench fathers, twenty sisters and 3,200 native converts. There was food enough for about 500 usually living in the place, but the task of feeding six times that number was a serious one. At first the Chinese had eight ounces of food per diem, but toward the end they were only allowed two ounces. The men worked well so long as their strength remained, but afterwards could not do much more than crawl around and keep up mere existence. The supply, such as it was, chaff, grass and leaves of the trees, could have lasted only a few days more, and then famine and pestilence would have occurred. The foreigners fared better, as their strength was indispensable for the defence.

The attack began first from Boxers on June 15 th, when fortyeight of the enemy were killed. By June 2oth, the day war was declared, the soldiers appeared, and ever afterwards continued to be the chief factor. On that day they also began cannnonading, firing with one grun straight into the main entrance of the Cathedral grounds. The marines made a rush upon the enemy and captured the gun, which was the only gun they harl through the whole siege. The cannonading thus began earlier than at the Legation, and was also morc severc. The Jritish Legation never had more then three guns playing upon it, while the North Cathedral for as many as three days had fourteen guns, and as an ordinary occurrence as many as four, one being fired from the Palace grounds and another from the Palace of Prince Li. There were twenty-eight days of successive shelling being four days longer than the whole period in which there was shelling on any of the Legations. During these days as many as 2,400 shells were fired, and on one day, June 24 th, 3 So shells burst into the grounds.

The only defenders of the Cathedral and its vast crowd of helpless refugees were the thirty Frenchmen and the ten Italians, who were scnt from the foreign guard. 'This was better than the British and Americans allowed for the Protestant headquarters, there being no British guard allowed at any time, and the American guard of twenty ordered to return to their Legation on June 20 th. The forty foreigners who fought at the Cathedral were stationed at six different places, where stronger fortifications were made. The French were supplied with 2,000 rounds of ammunition, but the Italians had less. 
As soon as one of the number was killed a Chinaman would take his place. Night and day this small number had to keep watch and be ready to resist every device of the enemy. The shelling left its effect on nearly every building as weIl as on the Cathedral itself. But the greatest injury came from the effect of powder explosions. Four mines were dug and exploded, all being at the north end, where the Foundling Hospital was situated. As many as eighty persons were killed from one explosion, and four hundred in all, 120 of whom were children. The loss among the natives was almost entirely from the mines. 'The Foundling Hospital is now a total wreck, and a fitting illustration of the real design of the enemy.

At the beginning as many as 600 of the native converts were armed with swords and spears, but when the Chinese soldiers began firing shot and shell, such equipment proved useless. Forty rifles and one gun were the defence against, say, 2,000 rifles and a dozen guns.

However superior the strength and number of the enemy, they made no attempt to assault and enter the place. The shots from the French were too well aimed to encourage such an attempt. A kind providence rested over the place, and the united prayers of each morning brought their blessing in rich munificence. The enemy who fought and the Empress and advisers who schemed had clearly one intent, and that was the annihilation of the body of the Christians, who never fired a shot except in self-defence. To the credit of Catholic France and Catholic Italy this calamity was prevented. The defence was one of sublime heroism.

The head of the mission was the leader of courage. Bishop Favier, while untrained to martial deeds, maintained cheerfulness and hope, and by calmness of spirit and trust in God kept in check any panic amongst the converts and all despondency among the marines. Half of the Italian defenders and both of the French officers, with three marines, were killed, or one-fourth of the total. However desperate the position, the Bishop never lost heart, and now that the awful havoc here and in the country round becomes known, he shrinks not from the task that lies before him, but resolves to begin anew the foundations of the church, confident that past horrors and present gloom will be changed speedily into glory and prosperity.

The Allied forces entered Peling on the I 4th August, but nothing was done to relieve the North Cathedral until the I6th. If relief had been immediate, or even on the morning of the I 5 th, the escape of the Court might have been cut off. As it was, there was a force of 1,200 men, composed equally of French, Russian, British and Japanese, to attempt the relief. When I reached the Imperial City gate a little after nine on the I6th, the French were still pouring shells through the gate into the city, but hesitated to march in. Along with a few others I climbed over the Imperial walls and entered the Cathedral grounds by a side entrance. There was very little resistance to our troops, and so they marched on, past the entrance to the Cathedral into the Palace grounds north of the Palace. There were fired a few 
shots by the Chinese along the street, but none from the palace quarters.

Thus the relief of the North Cathedral resulted in the occupation of the palace grounds, leaving only the circuit where the palaces are untouched. The American were unfortunately left out, but they had succeeded the day before in occupying all the Forbidden City at the south up to the fourth gate, which looks directly into the Palaces. The palace of Prince $\mathrm{Li}$ was afterwards occupied by the French, though within the American section. The French had this part of the city set apart for their control, and thus secured in silver upwards of $£ 60,000$, part of which was transferred to the North Cathedral on the indemnity fund.

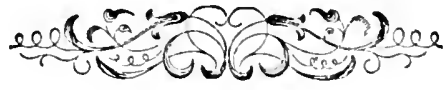




\section{TIENTSIN TO PEKING BY BOAT.}

The river from Tientsin to Pelsing is in the hands of the military authorities and is the main line of communication with the capital.

To judge from the activity of the Japanese and British, and the number of transports and men employed by both, there is no present intention of evacuating this part of China. 'The river is well patrolled and strong guards are placed at short intervals. At Peitsang the Japanese, Americans and British combined ruard the place and control the bridge of boats there. These three powers work well together, and apparently share a common admiration one for another.

In addition to the river route long lines of carts drawn by both mules and men are strung out along the road and make the journey in shorter time than the cumbrous boats.

The country is deserted by its ordinary inhabitants. In some cases the villages are still burning, and everywhere along the river the boatmen conbine to strip both houses and fields of anything portable still left in them.

When they come to a village between the posis the boatmen scatter through the houses and carry off furniture, doors, windows, farm implements and so on to the river bank. The loot is then thrown into the water and fished out by the men on the boats with boat hooks and soon reduced to a convenient form of fuel, only a few of the better things being reserved for future use.

Leaving Tientsin some of the men tried to carry off two only from among the million bags of salt there stored and guarded by the French, but a few shots from the soldiers rounded up the whole convoy and ended in the apprehension of an innocent man and a search of the suspected boats.

At Yangtsun there is a badly constructed bridge of boats across the river that causes much delity and some loss of property. The day we were there a long convoy of mule carts belonging to the British, in charge of some Indian soldiers, had the right of way and blocked the river traffic for a considerable time.

One of the carts, rather heavily laden, drawn by two fine mules, lurched over the side of the bridge, carrying the mules with it and the whole was speedily engulfed in the muddy stream below. The same thing had occurred to a French convoy at Peitsang a day or so previously.

At Yangtsun the Russians have an cxtensive canly with forges 
and a corps of men for the repair of the railway. The fine bridge across the Peiho at this point was unharmed by the Boxers, who contented themselves with tearing up the rail bed, leaving the bridge intact.

There is a grood deal of grumbling going on about the administration of the railway by the Russians. Both Germans and British assert that a change of operators will soon take place, each claiming the post for its own nationals respectively.

Yesterday we strolled out along the bank of the river and while waiting for the convoy to overtake us went into a neighbouring village to "makce look see." One solitary man stood at the farther end of the village street and promptly took to his heels as soon as two men in khaki came into view.

There is a wholesome fear upon all the country side and unless some steps be taken to reach the well disposed among the frightened people the question of ultimate supply for the vast number of people already here and those coming will be more difficult than it needs to be. The harvest is ripening fast but uselessly unless men are at hand to gather it. If allowed to waste, the ensuing sufferings of the Chinese and the enhanced prices of outside supply will be a serious problem to dea! with.

On Sunday evening, September I 6 th, we heard heavy firing along the river in our rear. This was the signal for hurrying up the boatmen and and by dint of much pushing we reached a Japanese post where we found quite a flotilla of boats tied up for the night. By the time our shouting, cursing coolies got aboard for supper and rest, they were too tired to do anything than crawl beneath the easiest found cover and go off to sleep.

Not for long, however, as a violent thunderstorm with much wind broke over us and roused all hands to get out and see to the anchors lest we find ourselves adrift upon the river in the darkness.

This day we passed several festering corpses on the river bank, around which the gorged and indolent vultures sat in large numbers. One body, that of an Indian soldier, lay on the sandy bank, brought down evidently by a recent freshet. The lhaki uniform was clogged with sant, and the hand and foot were raised as if in action and death had caught the pose.

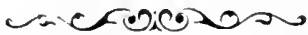




\section{PEKING DAY BY DAY.}

30th September.-The last place in which to hear anything of Peking is at Peking itself. The loot shed in the morning, the Legation auction in the afternoon, with the usual run of meals graded to an Indian scale of living, and that completes the daily routine: but loot is king. Whenever the Shanghai papers arrive we hear of probable evacuation of this city, but everything here is arranging itself as if permanency of occupation were a foregone conclusion.

Winter has given us an advance intimation of its intention, and the call is for winter clothing.

The city presents a very doleful aspect to the eye. The streets are in large measure deserted, many indeed are in ruins. Trade is quite at a standstill outside the demands of the foreign troops, and one misses entirely the hum and bustle formerly characteristic of the place.

The British troops are quartered in three main camps-one at the temple of Heaven at the extreme southern limit of the Chinese City, one at the south-west angle of the Tartar City and the principal one at the Legation and adjoining streets. The buildings of the great departments of government, such as the Board of War, the Board of Rites, etc., are used for various administrative purposes under the new regime. Great alterations are being made, thoroughfares opened, roads cleaned and tons of books, papers and other accumulations are being burned. It is a curious comment on the mutation of life to sec documents written in both Manchu and Chinese being carted off to the refuse pile to await burning. A big yard adjoining the Imperial Palace has been converted into a local Tophet, where the fire is unquenched. Holes have been driven through semi-sacred walls and the foot of the alien overruns the most exclusive preserves.

A somewhat singular thing is that most of American and British residents not in military lines live in the Russian districts. Huge rich houses have been allotted to the various missions which are allowed to recoup themselves for their losses by the sale of whatever things they may find in the place.

One mission premises is in the charge of a plucky lady missionary who performs the function of a district magistrate in addition to the care of a large number of Christian converts and scholars. It is no uncommon thing to see one or two Boxers tied up in this lady's courtyard, and the casual caller may be surprised at the sight of her examining prisoners and dispensing justice to them.

The capture of thieves and Boxers does not seem to be the exact 
function of a lady, and a missionary lady at that, but this one is doing fine work in her newly occupied compound beside the ruins of her former mission. The care of three hundred native Christians, the disposal of a big house full of Chinese goods, and the policing of a large turbulent district is a task that might employ the abilities as well as the resources of more than one man-but this plucky woman does it to the admiration of all bcholders.

Ist October. - The town is agog with prospects of an expedition. International it can hardly be called in its wider sense, since three of the principal Allies are not to be represented on the force. German and British soldiers are to form the column which we all hope will move out in three days for the city of Paoting-fu.

To-day we had a little scare. The Russians sent a despatch to the British saying that fifty thousand Chincse were marching on the city, therefore the guards at the gates should be strengthened. The compounds of the various regiments were soon in an orderly tumult, every man rushing for his arms and accoutrements; rifles were stacked and every thing looked like active service for a while. But towards night things settled down, and it began to be whispered around camp that Russia was trying a fake on us to get the troops out of Fengtai on a false alarm, when she herself could step in and take possession, as she so deftly did on a like rumour at Machiapu.

3 rd Octolver.-The sumber palace, which has been in the possession of the Russians since the occupation of Pcling, was to-day vacated by them, and has now been garrisoned by a detachment of British troops with whom are associated a detachment of Italian soldiers, though why a number of British troops should be taken from the scanty number now in Peling for such a purpose is not quite obvicus.

There are a goodish many discordant notes in the concert of the Powers, and a fair amount of speculation on the future. It is safe to say that every one is tircd of the continued inaction, and gorged with loot to a greater or less degrce.

The one anomaly is the Impcrial Palace intact amid the ruins, guarded by troops at all sides, but if common report may be beliered it also has received its share of the looters' attention. It is surely in order to bring the ycllow tiled exclusive buildings that dominate Peking into line with the sencral desolation of the city, and so make it an object lesson to the cntire Empire.

The changes now being carricd out in the "six boards" will startle the old inhabitants of those musty dwellings. Roads are being constructed, doorways are opened through, and a general clearing up for ages past is going on.

Tons of precious documents (precious to the old bureaucracy) are swept up and conveycd to Tophet in a yard adjoining the Palace, where the smoke of them goos up daily:

Private and important documents are blown with the common dust in a fashion that would completcly flablbergast the moss-grown officialism now forcibly ejected from its wonted sp heres. 
5th October.-The Ninth Regiment U.S. Infantry left to-day for Tientsin and parts beyond. It seems scarcely the thing to recede from the position won by hard fighting here at Peking. The real need is for advanced work, and for this reason there is general regret that this fine regiment should be recalled.

To-day we hear that the Germans have made a move in the direction of Paoting-fu, welcome news, though more than a tinge of disappointment is felt by that part of the British force which had expected to go on this expedition, and now find themselves left.

The Germans are surely entitled to a "show" all to themselves and thus win for themselves and their country the prestige of avenging the foul murder of their ambassador. At the same time, individual action in a concert of Powers is an anomaly not explicable to us at present.

Regarding the railway we hear a curious piece of news. It is talked among the men here that by German "decree" the railway from Shan-hai-kuan to Yang-tsun is given over to the Russians and from Yang-tsun to Peking the Germans themselves are to take the road. This is astounding and directly conflicts with all sense of justice. That a railway built largely by British workmen, in which also British capitalists are largely involved, should thus be summarily handed over by "decree" to other Powers indefinitely is an enigma on any other supposition than that Britain has received compensation elsewhere. Query, is it in the Yangtze Valley?

Does German isolated action foreshadow ultimate partition and also indicate the lines thereof? If the north is for Russia, the adjoining districts for Germany, then Britain and the rest must seck compensation farther south.

The opinion of men on the spot here is that British interests in the north are not of sufficient magnitude to warrant a conflict or even a misunderstanding with Russia regarding this territory, but that a mutual agreement between these two highly interested Powers should be made, removing all friction and so open the way to a lasting and beneficial understanding and co-operation.

6th October.-Yesterday the British and Italians occupied the summer palace on its evacuation by the Russians.

When the latter left the place a few red button mandarins went in as caretakers in the Chinese interest, but were summarily ejected later when the new occupants arrived. The Russians had carried off many of the rarer articles of value from the palace, but a considerable remnant was left when the British arrived. With this force the chief diplomatic servant of the British Empire to the Court of Peking also made his way to the summer playground of the fugitive Empress, and for a time active looting was the order of day, the "Tommies" being used by their superiors for that purpose. Such a course as this, however undignified it may be on the part of high officials of the state and army, could not be grumbled at if men in the lower ranks of the service were allowed some kind of a show as well.

Recognise looting and then, making due allowance for difference 
in rank, give every man a chance. This is not done and hence the unfairness of the proceedings. When a certain a mount of cream has been skimmed by these privileged individuals from the loot pot, out comes an order against lootine that deprives every one else of his chance of doing it unless he takes serious risk of disregarding the order and so defy the authorities.

This whole loot business is a bad and demoralising thing. It should be prohibited once for all and an end put to a condition of things little short of a scandal.

Around Peking, and even inside the city, the Boxers seem to be taking heart of grace again and turbulence is on the increase. Robbery with violence gocs on, not only among the Chinese, but some of the Boxers carry the war into the premises of scattered unprotected foreigners.

The Japanese quarter is in the best and most prosperous condition of any in the city.

There the people have largely returned to their homes and avocations, and the hum of city life is in the air.

In the quarter of the Chinese city under the energetic control of Captain Barrow of the British force something of the same kind is also observable, but something of the nature of an advance into the surrounding country is essential if the prestige of our arms is to be maintained. The opinion is strong among the Chinese that having taken Peking the allies are either unable or unwilling to do more and the conditton of the country twenty miles out from the city is certainly unsafe. It does not speak much for the impression made on the Chinese that it is not advisable nor allowable for one to go from Tientsin or even from Tungchow to Peking without an escort. During this splendid weather, when forage and provisions are obtainable in any direction, a couple of mobile detachments of two or three hundred men apiece might be sent out under the command of some energetic younger officers whose names are yet to be made, and the whole country side might thus be cleared of malcontents and confidence restored among the harassed villagers.

Sth October.-Rain and cold winds have prevailed to-day. The force is shivering in the murl, and making strenuous demands for warm clothing. One of the entertaining sights of Peking is the show made by the stalwart Baluchis or Sikhs, with their pagoda-like turbans over flowing locks surmounting an array of Chinese women's robes of many patterns and colours, worn in picturesque confusion and prodigality.

Ioth October.-There is a bright sun shining to-day after the gloom and rain of the past day or two. A brisk wind is breezing up and already the dust is eddying around every convenient quarter, and blowing in stifling clouds down the broad desolate streets.

It is either slush or dust-no mcdium. The slush is impassable, the dust is impossible. The one fills the city with quagmires and sink holes, the other fills you by every possible avenue, nose, mouth, eyes 
and ears-all full of Peking dust. And such dust ! a little reflection makes the situation unbearable.

We hear that typhoid is rampant in some sections of the city. Typhus is rife in the German quarters: dysentery in the French, but every day tends to lessen the chances of the fever spreading.

Preparations for the Paoting-fu expedition are going on gaily. Great is the disappointment of the men who are forced to stay behind here, and so miss " the show."

French, Germans, English and Italians go together and I hear they are carrying a large lot of dynamite.

I th October.- $\mathrm{Li}$ Hungchang arrived to-day under Russian escort, whether as guest or prisoner is undecided.

The expedition got itself into shape for starting in glorious weather and high hope. A rather curious coincidence-the arrival of the peace commissioner and the departure of a punitive expedition, but probably the latter may hasten the work of the former in direct ratio to the punishment inflicted on the guilty city to which the column goes.

I2th October.-Li Hungchang called on the British Minister and had to be helped up the steps of the Embassy. The old man is very feeble but mentally keen and as shifty as ever. No word of the interview has transpired.

An interesting bit of news is received from the expedition. It is reported that the Chinese Imperial army lies across the road the expedition must take in its march, and refuses to either fight or clear out.

It will be interesting to watch the result. Sir Alfred Gaselee will hardly leave so truculent and unamiable a set of men on his line of communication, yet how to remove them if they persist in their present attitude and not fight them is a problem of no mean dimensions. Meanwhile Peling is very quiet and the task of amassing supplies for the winter goes on unceasingly in the British lines.

The Russians are moving out and their old quarters are being occupied by the Germans and Italians.

'The former have served notice on several families in their lines that the British flag must be removed from their roof-poles: the latter have served a notice of removal upon an American family residing in a part of a large palace within their lines.

In neither case will the notice produce much effect, I think. "Sit hard and keep quiet" is an effective order of campaign in relation to such a crisis.

I 3 th October-Yesterday I heard an interesting rehearsal of his experiences by an American missionary who has just returned from Tungchow, where he has been for the past fortnight trying to settle up the vexed questions of compensation for outraged Christian families in the villages round about that city.

He reports about one hundred murders among the Christians and adherents of the mission scattered through thirty villages.

An escort was provided by the U.S. authorities as a means of protection, but the mission was one of adjustment and pacification, 
hence force was in no case to be used other than that needed to protect the party personally.

The plan of settlement agreed upon was indemnity for houses and furniture destroyed: ground for the erection of Christians churches and for cemeteries for Christian use: and suitable monuments to the murdered folk.

This basis was accepted gladly by the elders in the implicated villages and security given for the money compensation and the transfer of the necessary land.

The report of the attitude of the Boxers was, however, not reassuring. The report shows them to be more hostile than at any previous period, while proclamations are out calling upon the members of the organisation to asscmble and carry out active measures against the foreigners and the Chinese Christians.

The magistrate of one county ncar Tungchow has been slain, another has thrown up his office because unable to control the sitution, and everywhere there is a recrudescence of the worst spirit of the Boxer movement.

Any movement in this quarter would be likely to affect our line of communition with ' Iungrchow and the coast, and might prove to be very embarrassing in the depleted state of the forces at the present time.

Street talk in Peking is that Li Ilungchang has come up to organise the Chinese forces for victory. Tungchow is to be attacked and the foreigners destroycd, then the victorious army is to move upon Peking and wipe out the hated foreigner, For the success of such a move, however, it will he necessary for the Chinese to secure the absence of "the while angel" which hovered above the Legation during the previous siege and so diverted the shot and shell that it came out of the conflict practically unharmed and unhit.

Igth October.- In a howling cloud of dust, dust in the air, and in favoured ridges on man and beast, the Cuunt von TValdersce arrived in Peking to-day.

Attended by a numerous staff, brilliant probably had the dust not tarnished it, with an escort of Indian and American cavalry, the new commander of the Allied Forces entered the Imperial City shortly after the noon gun had boomed out its customary notice from the British Legation lines.

On Monday we were startled by much gun firing in the forenoon, but were reassured later to find it was a pacilic noise- the rejoicing of the French soldiers at the arrival of their own special general, who thus arrived in time to welcome his more illustrious German confrere. To-day there was a general parade of the troops in the city and from the Ha-ta-men to the Imperial city the Iield Marshal passed between clouble lines of soldiers, none looking smarter or better set up than the i Sth Sikhs and the Baluchi regiment: the former in their winter clothing faced with yellow braicl well set of by their dark slinned faces overtopped by enormous shapely turbans; the latter in red rtousers and white spats, a set of men much above the average in 
height and size-every inch of them alert and full of military energy.

An escort of American troopers and Bengal Cavalry formed the Marshal's escort while a motley crowd of horsemen, iwagons and dusty travellers closed up the extended procession.

Li Hungchang, feeble in health, but apparently nimble in mind, goes round from one embassy to another in the interests of his alleged mission under the care of Russian guards who "tote" the old man round with bayonets fixed.

Query! Is he guest, host or prisoner?

20th October.- There is a strenuous repetition of the Boxer propagandism.

Everywhere Chinese are talking of another rising, this time by the "true Boxers" who are now to be distinguished by a white girdle and head band. The date fixed is the ninth day of the ninth moon, the original date of a concerted national rising.

Outside the Chiemen a party of armed Boxers attacked a wealthy storekeeper and killed the old man, wounded his son, and began a loot. The son, however, raised an alarm, the Boxers ran, and ran clean into the arms of a German post. There are several Boxers the fewer because of it.

In another quarter of the city a noted Boxer levied blackmail in the name of a well known American missionary, and in this confidence became the terror of the neighbourhood. Some men were sent from the Mission to "inquire" of him regarding this little procedure. They were met with a bayonet and retired with three wounded. The German soldiers speedily came on the scene, arrested the unwisely aggressive Boxer, charged him with his offence and asked "Are you a Boxer?" -to which he stoutly answered "Yes I am": Result was a short shrift beside a stone wall and a dead man carried out.

Another case even more significant was that of an interpreter attached to the British forces who with some companions sought admission to a house in order to inspect the back wall of a house needed for the troops. The owner refused to open his door, which had to be forced from the outside. The intruding party was met with the business end of a Winchester rifle. Retreat in good order and quick time ensued, a guard was called, the place re-entered, a scuffle followed, and the unwise aggressor was carried off to the delights of a prison and the enforced companionship of his co-Boxers.

North-east of the city there is a large tract of country almost wholly in the hands of the rebels; the Magistrate has been killed, and a reign of anarchy is in progress.

October 25th. -The news from the Paoting-fu expedition is satisfactory so far as it goes, but it doesn't go far. The city is in the hands of the Allies, a party of long imprisoned and hardly beset missionaries has been rescued, and now a part of the column is returning here, leaving the Germans and Italians in possession of the guilty city.

An international council sat to determine the guilt of the different 
officials and award punishment, but the finding of the Court has not yet been published.

In Peking itself all is quiet and the absence of news is phenomenal. Meetings of Ministers and others take place but nothing leaks out as to their doings. The whole situation is an impasse of the most perplexing description.

Sir Claude MacDonald was escorted from the city where so much more was expected from him than he has accomplished, that his departure lends a ray of hope, or better perhaps it is to say that it excites a certain expectation that the new Minister may infuse some vigour into the British share of the international problem.

The next item is to welcome back the Paoting-fu contingent and then amuse ourselves with speculation as to the next move: only give us movement, anything but the dull round of present Peling stagnation.

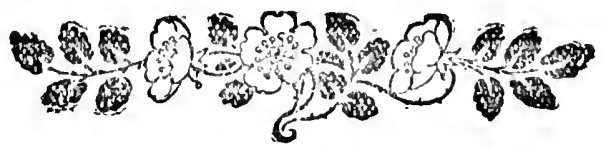




\section{THE PAOTING-FU EXPEDITION.}

Tientsin, 24th October.-News has arrived here of the Paotingfu expedition having reached Kaoyang-hsien on the Igth instant. The official at Reuchiu did all he could in the way of supplies for the troops, and also built a very good bridge across the river, thereby facilitating the advance of the column to Kaoyang. At this latter place a good deal of pride and obstinacy was shown in the behaviour of the people. A correspondent writes "They would not even carry out the provisions which were prepared for the troops," and hopes they will be treated as they deserve, but fears they will not.

He adds "We stopped the Imperial courier yesterday and took his papers from him, finding nothing important however except a communication from the authorities at Paoting-fu to the surrounding magistrates, stating that "foreign soldiers had arrived at Paoting but it is not known for what purpose they had come; that they had been ordercd (sic) to camp outside the city, and certain villages had been assigned to them for camps."

It is reported that the French troops who succeeded in getting possession of Paoting-fu almost before the allied force had left here, were a kind of advance guard! Strange, however, that they left for "destination unknown," but it is possible that their chief object in starting out was to rescue the French priests who for almost five months had with their converts been so bravely defending themselves near Paoting-fu, the attacks upon whom were lately linown also to have been tiercer than ever. IVe are glad also to know that these same men have now been relieved. The story of their defence will prove a wonderful story. But again, if it is true as stated, that this French force has consented to ransom the city of Paoting-fu for 'Tls. 400,000, will the allied force be thercby prevented from executing punishment on those who were concerned in the murder of so many American and British missionaries last June? However, as the united forces are at Paoting-fu by now the question will probably be settled, and I hope not by a mere money payment.

Reuter's agent here has received a telegram from Peking which says:-"All Paoting-fu missionaries surviving and handed over to the French." We are anxious to know if the party who for so long have been sheltered in Chengting-fu had got on to Paoting-fu, as had been arranged, and would therefore be included as "surviving" in Pao- 
ting-fu. WV hope before long to see them all here. Hunted and driven so long it will be a change for them to feel secure again.

VVe are reminded by some of the correspondence on Missionary massacres in Shanghai papers lately to hand, that "any fool can be wise after the event." Even in N. China it was the general opinion that the Peking Government upon seeing the world in earnest would at last back down, and stamp out the Boxer movement. The shelling itself was no more a surprise to us here than the announcement that China, so lately beaten by Japan, was now prepared to defy the world! We know that "whom the gods wish to destroy they first of all cause to be demented," but China hitherto had rarely if ever refused to listen to such vastly superior force. Her action was absolutely unprecedented, how then could it have been foreseen?

Your native contemporaries in Shanghai in talking of the present statc of things here little understand the freedom which natives now enjoy and the glorious opportunity the occupation of Tientsin by foreign troops has given to many to become rich. If the few rich have suffered and many poor, yet it is probable that the majority of the poor may be better off at the end of the war than they were at its commencement. The thousands of coolies who are in daily cmploy, household servants, interpreters, etc., etc., are mostly getting double and treble the wages they could obtain before and the country people who bring their produce are just minting money. They expected to get rich by joining the Boxers and looting us, now they sell us their goods for what they like to demand instead. The shopkecping classes have suffered most and were perhaps the most innoccnt of designs on the foreigners.

So far but few troops have really left here but we still hear of their being "about to leave."

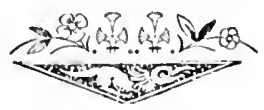




\title{
THRILLING EXPERIENCES OF C.I.M. MIS- SIONARIES IN CHIHLI.
}

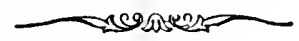

\author{
(A Detalem Account of the Wanderings and Marvellous Escape of \\ Mr. and Mrs. C. H. S. Green, Their 'Two Chlldken, Vera \\ and Jolin, Agei respectively Five and Three \\ Years, and Miss J. G. GreGg.)
}

$\rightarrow$ sеตе

\section{Written by Mr. and Mrs. Green.}

It was very soon after our return to Huailuh on March 30 th that gradually increasing rumours of trouble with the Society known as "The Boxers" in the district north of Paoting-fu reached us, and by the micldle of May things seemed to be getting really serious, though one learns by experience to "liberally discount" all rumours in China. Authentic items, however, were sent us by Mr. Bagnall, our missionary at Paoting-fu, in the fortnightly mail, and these reached their climax by the couriers who arrived at Huailuh on June 2nd bringing news of the destruction of the railway and the attack on the party of engineers in their endeavours to escape to Tientsin by the river.

This meant that all communication with Tientsin and the outside world for our part of China was entirely cut off. Even this mail contained no foreign matter for us and we neither received from nor were able to send away word to friends from about the middle of May. On 'Tuesday, June I2th, I received two wires, within an hour of each other, one from Tiertsin and one from Paoting-fu, asking me to send a special messenger to Shuenteh with word to stop Mr. IV. Cooper coming north to Paoting-fu and advising his return to Shanghai via Honan. I had already sent a letter two days previously by cart, strongly advising that he should not attempt to get to Tientsin at any rate by the Paoting-fu route.

To save time I sent off one of my own servants (he was away before the second wire arrived) with orders to travel day and night, if possibly he might catch dear Mr. Cooper before he left. He was 
back by Friday afternoon with word that Mr. Cooper left Shuenteh by cart for Paoting-fu the same day that my courier left Huailuh.

I immediately wired Mr. Bagnall asking if he had arrived safcly, as I knew that he must pass at least one place where the Boxers were giving trouble.

We were filled with praise the next morning to have a reply, saying he had reached there safely. Also when two days later we had letters by mail from Mr. Cooper and Mr. Bagnall to tell us although the clouds seemed gathering they were kept in peace and that all Mission premises were under military protection.

The continual drought in the Province caused much unrest among the people and no doubt tended to accclerate and strengthen the anti-foreign movement. There had been no rain practically since carly in July last year. The autumn crops had been a failure. The wheat for this year's spring could not be sown, so there were no spring crops, and now the time for sowing the autumn crops was fast passing away and still no rain.

'I he anti-foreign party, taling advantage of this, issued broadcast inflammatory placards saying that there would be no rain until all foreigners were exterminated and various other very injurious accusations. Although there was much idle talk and growing coldness of attitude to us in our district, we first began to be uneasy when we found that these placards were being posted in the neighbourhood.

This was the same week that the railway was destroyed, news of which had already rcached us from native sources. After prayer and talk together I was led to send a letter to our local official, telling him about the injurious placards and asling him to lo what he thought was right in the matter. He quickly sent a very kind reply by one of his secretaries assuring me that he would suppress such foolishness and give us protection. This being our first dealings with the Magistrate, a new arrival since we went on furlough, we were glad to find that at least our local magistrate was not "anti-foreign."

From this time forward the local natives and our own dear Christians and inquirers became more and more uneasy.

Daily rumour and reports were current of the murder of foreigners, native Christians and Catholics. Also threatened attacks upon the large Catholic Mission premises at Chengting-fu, twenty miles east of us, and even upon our own places, began to be circulated. Many of the more friendly natives visited us and sought to assure us that, whatever happened elsewhere, the Huailuh people would never do so, or allow any violence, that we must continue to pray for rain as all would be too busy to listen to idle talk when sowing crops for atumn, and their hearts would be set at rest by the removal of a threatened famine.

We gave ourselves to much prayer and waiting upon God and encouraged our Christians to do the same.

Truly for them this was a time of fiery trial. They were "counted as the off-scouring of all things" and knew what it was to 
be "despised and rejected of men" and being "of the people" there was no respite such as we had in the privacy of our own home. In almost every case there is only one in a household and so they had to stand alone, but not alone for the Lord stood with them and strengthened them, and our hearts were made glad as we saw the grace of God manifested in them.

About midnight on June 12 th our household received a shock which more or less unnerved us all, coming at such an anxious time. It was full moon and exceedingly hot and we were sleeping with our own bedroom door wide open to get any little breeze there might be, when at midnight I was awakened by a slight cry from my little boy. On opening my eyes, there, right between our bed and the bright moonlight, at the door I saw a man in the room! Without waiting for second thoughts I sprang from the bed and went for him. The same cry that awoke me had startled the thief, and we moved simultaneously. My nightdress became entangled with my legs causing me to fall heavily in the court-yard outside. Although I was up again quickly and gave chase, he had gained on me sufficiently to make himself invisible when we got to the back court-yard, where are several large trees giving shade. After standing for a moment to make sure there was nothing moving, I thought it wise to call up the household and make a search. WVe soon scoured the place armed with cudgels, pokers, spades, etc., but he had made good his escape and had got clear away, while I returned to call the men. We found traces of him in other parts of the premises, but could find nothing missing. Alas! on going to dress next morning I found the complete set of clothing I had taken off the night before was non est and a few minutes after one of the servants found one of my socks on the top of the back wall, giving proof positive at least of the way of exit. All the natives were loud in their expressions of thankfulness that $I$ did not succeed in catching my man, assuring me that no Chinese thief goes unarmed, at least without a sharp knife, and that I was sure to have been badly wounded. The Christians maintain that our merciful God caused me to trip in the yard and thus save me from something worse than the grazed knee I received. The next day and onwards we were very careful to lock up all doors and put away all movables. The thief having learnt his way about came again the following night and made off with a valuable brass gong, hung on a tree in the centre court, which we used for calling the natives to service. TVe found trace too of his having tried other doors. The third night we planned an ambush for him, four of us waiting all night in a room at the back, close to the place where he climbed over the wall. We had evidence that he and others came to the other side of the wall, but probably being in some way alarmed or hearing some slight sound we may have made they did not attempt to come over. The fourth night we planned for our men to sleep in different parts of the compound and to be on the alert. About midnight again an alarm was given and we all sallied forth with our weapons and made a vigorous search. A 
cudgel was found left leaning against one of the doors at the back but no sight of the thief. These midnight alarms continued, whether real or false. several nights. I cannot tell why, but this matter coupled with the growing seriousness of the trouble throughout the province seemed to unnerve us all and it was only by a constant waiting upon our faithful God that we could get any heart rest. At any ordinary time we should have reported the matter to the Yamên and had it stopped quickly, but having so recently written to the official about the placards and more serious trials now coming upon us we did not act in the matter of the thief. Perhaps it would have been better had we done so for very exaggerated accounts of the affair were rife in the city and perhaps helped forward our next trouble.

It was just about a week after the thief's first visit that our table boy went out to buy provisions and was waylaid by a friend who whispered something to the effect that he was on no account to sleep on the foreigner's compound that night, as fifteen or twenty local blacklegs had planned a midnight raid upon the place pretending to be "Boxers." They intended to "hold us up" with fire-arms and make off with any plunder they could get. Although we usually ignore these kind of tales there seemed a good colouring of truth about this, and knowing lawlessness was spreading all around, the boy himself being very frightened too, we were led after prayer to once more send a letter to the mandarin asking for protection.

Again the secretary was promptly sent round with a letter and word of assurance, so that evening and the subsequent three or four nights a guard of eight or ten underlings patrolled the place outside. I was waited upon by two of the local policemen who assured me what diligent care they were taking of us each night, which is the Chinese way of asking for a tip, and of course being Chinese I promised one. All these days I was kept busy sitting with the numbers of natives who came to see me, chiefly out of curiosity, I think. IVe were now the principal topic of talk in the city and many came to assure themselves that we had not run away, as it was so persistently rumoured. Others again advised us to leave for a time, either to go into Shansi or else to the coast, offering to procure mules or carts if we needed them. The special messenger returning from Shuenteh brought word that on Sunday, June 25 th, the people there assumed a very riotous attitude, wathering a crowd, shouting, etc., but that they had dispersed quictly and our friends there did not anticipate any serious trouble just then. On June 27 th and 2 Sth the Shansi couriers of our own and other missions called at Huailuh as usual, cn roule to Paoting-fu, but by Saturday, June 3 oth, they had all returned, having only been able to get about two-thirds of the way there. The roads were guarderl by Boxers, and any one found carrying foreign letters was killed on the spot. One courier belonging to the Catholics at Chengting-fu had been killed that week and later we heard that several others harl shared the same fate. IVe were now cut off from any communication with Paoting except by telegraph and we realized that the danger was coming nearer to us, 
as Ting Chau, where the couriers were murdered, was only about sixty miles from Huailuh. On Saturday, June $30 \mathrm{th}$, an abundant rain commenced, which lasted more or less for three days and was sufficient to allow the later autumn grains to be sown, thus saving our district at least from the long dreaded famine. The character of the rain too led us to hope that it must have fallen over a very wide area. When at last the rain came, after long continued prayer and the strain of waiting, we could not keep back tears of thankfulness and perhaps from the little incident something may be gathered of what those days had meant.

Our ladies and the children when the storm approached were in the garden and the first peal of thunder attracted the attention of the little ones who ran to Miss Gregg clapping their hands in delight crying, "Oh, auntie! its thundering." "The rain's coming! Praise the Lord!"

We had a series of praise meetings that day and the Sunday following for the Lord's goodness in graciously remembering His people and these poor Chinese.

We trusted that now our troubles were past and rejoiced that the people would be all busy on their land and more peaceful times were at hand.

On Monday, July 2nd, I found a man willing to attempt to reach Paoting-fu by a circuitous route with one letter secreted in his clothing. He was about to start, but the rain coming on again he decided to wait until the next day. Just then I was led to send a note round to the telegraph office, asking the clerk, with whom I was on friendly terms, if he had any news from Paoting-fu or Taiyuen-fu. Our little household were at prayer when the messenger returned with a reply from the telegraph clerk to this effect:- "He had just learned on the wires that all the mission premises in Paoting-fu had been destroyed the previous day, and all the foreigners killed except two ladies who had been carried into the district yamên, and that many natives both Protestant and Catholic had perished." The Lord Himself gave the grace for receiving this sad news. I tried to believe that it might not be true and immediately wrote out a wire to Mr. Bagnall, asking if all was well. Word was sent back from the office that the wires had just been cut somewhere between Huailuh and Paoting-fu, but they hoped to have it repaired quickly. Early next day, Tuesday, July $3 \mathrm{rd}$, a reply came to the effect that there was "no receiver" at the China Inland Mission for my message. I then sent a wire to Shanghai with the information as I had first received it from the telegraph clerk. In the afternoon I wrote two hurried letters to send off special messengers, one south to Shuentehfu and one west to Sheoyang, with the sad news from Paoting-fu.

The same afternoon about 3 o'clock I was waited upon by two policemen for the promised tip to give the men who had been on night duty round our house. It appears that a local ne'er-do-well, seeing these two public men enter our place, had his curiosity aroused and he said, "What are you going to the foreign devils for? I'll go 
with you!" They, not wishing their business to be known, bustled lim off, and would not let him come in. The mischievous fellow, I suppose out of spite, went rumning all round the city and suburbs shouting, "They have set fire to the foreigners' place; such a lark, come along." A people who had been worked up to such pitch of excitement for two or three months needed much less than that to cause a rush and crowd, so that the police were only just nicely clear off the place when we were surrounded by a shouting, howling mob, who began to throw stones at the front door and in other ways became very rowdy. With all that had passed during the last few weeks to unnerve us, and our hearts still numb by the terrible news from Paoting, it will be understood what an ordeal this was to us.

My dear wife and Miss Grege remained in the inner court with the two children and I stayed near the front. Leaving there for a moment to encourase the ladies, I returned to find that our men servants, with true Chinese excitability, had opened the front door and were quarrelling and expostulating with some of the foremost of the crowd. I quickly got them inside again, shut and barred the door, remaining on the alert just within. I think the attitude of the crowd was more sport and curiosity to see what would happen than anything of a desperate nature, and I found that those immediately near the door were only children and youths. The grown-ups having withdrawn a few paces away were urging on the young folk to yell and throw stones, etc. I was led to go out alone and face the crowd, and ask them what the excitement was about. I dared not let the natives go with me, knowing that with their excitable nature there would soon have been high words and perhaps blows. The crowd fell back and many of them looked very sheepish as I went forward. But I found in trying to talk with them that very soon one more evil disposed than the rest came to the front, and by turning my words upside down tried to make out that I was cursing them, thus bringing the laugh of the crowd upon me. One or two of the more friendly then cried out, "Go back, teacher, it's all right; we are going to scatter now." So I returned, but it was quite dark before the crowd had all dispersed and quiet was restored again.

Shortly after our landlord called and stayed till near midnight, as he did again the following night, paying a third visit on the Thursday morning. Pretending to be anxious for our safety he urged us to leave, but his many and varied suggestions, as to what we should do, and where we should go, only proved that it was his property and not our lives he was so desirous to save. One can scarcely understand what an additional strain these interviews were at such a time.

Troops had been passing Huailuh for several days going North, it was said "to stop the Russians" who had invaded the empire from that quarter, and now came word that the. Governor of Shansi (Yuhsien) was on his way down with soldiers and a company of boxers, thit they hat alrearly reached T"aiyuan-fu, and were likely to cause trouble at any stations on the way. This official being a 
well known sympathiser with the Boser movement, and learning from the telegraph office that the Catholic Missions at 'T'aiyuan-fu had been burnt down, and some foreigners killed, we began to consider the advisability of seeking a place of retreat, where we could hide until he and his followers had passed through. A temple keeper, a few days previous, voluntarily offered us a room in his temple on a mountain near by. IVe sent a man to see the place, and make arrangements for our going if we decided to leave our home.

The next day, Thursday, July 5th, the tension increased. One after another came to urge us to hide. I sent out a man to gather any information he could from travellers coming down from the west, knowing that the troops only march about twenty miles a day and the ordinary traveller would soon be two or three days ahead. The whole city seemed to be in a fever. About 3 o'clock came a very unexpected blow.

A man arrived and was quickly ushered into my office, where I soon gathered that he was from Shuenteh-fu, that our mission there had been rioted on June 3oth; everything was destroyed or stolen and that the friends had escaped at midnight with just what they stood in to a village 12 miles away in the mountains, both the Hsien and Fu Magistrates refusing to see Mr. Griffith or have anything to do with them. He brought word too that Mr. Glover and family, in endeavouring to return to Lu-an from Shuen-teh, had been stopped and robbed, even the hired mules being taken off by the crowd; the nearest Hsien Magistrate had refused to have anything to do with the case. We heard later, however, that they had been sent on officially to Luan-fu. This man also brought us news that the L. M. S. Station at Hsiao-chang had been destroyed, but he did not know how the foreigners had fared. While he was yet talking to me, the man I sent out came in to say that a traveller from Shan-si had just told him the Sheo-yang Mission premises were destroyed. This was the nearest Station west of us, about three days' journey, and now we went to God in prayer for guidance; all the nearest stations around us, N., S., E. and IV., were destroyed; the Shan-si Governor and his troops were expected either on the morrow or the next day. So we were led to gather a few things together, just a change of clothes, etc., to leave the house under cover of night, and take refuge in our hiding-place on the mountain.

About ro p.m. we sent off three men with bedding, a few cooking utensils, provisions, etc., and just about midnight we, carrying the sleeping children, with one servant attending, set off for our three mile walk and mountain climb. It would be difficult to describe all we felt as we made our way over the rough roads in the dark, and it was just beginning to show signs of dawn when we reached the gateway of our retreat, tired and sick at heart, but realising our God to be "A very present help in trouble," and that we were offering for His sake. Nearly an hour passed before the temple keeper came to unlock the door and let us in. On unpacking our things we were distressed to find the oil stove on which we relied to make food had 
been broken; it was some time before I could make it usable, and we could get some refreshment. To our dismay, too, we found that the slighest sounds travelled most distinctly in these echoing hills and valleys; we could hear the conversation of the men working in the field several hundred feet below, and we knew that any sounds we made could be heard by them, so that it was one long strain all day to keep the children quiet in case our presence there should become known. There were temples too on the face of the mountain opposite, just across the valley, where lived priests and their labourers, and we had to be very cautious when coming outside of our room lest we should be seen.

The first day we saw no one from the outside world; much time was spent in prayer that God would guide us, and if possible bring us quickly through this troublous time and enable us to return to our home. We left three natives in charge of the house, with orders to hold the fort as long as possible, and one was to come up on the Saturday night, bringing us provisions and any further news of the situation. The temples, a small living room in connection with which we occupied, were very rarely visited by worshippers, except during the $4^{\text {th }}$ moon, which was a gala day there. The court-yard door was kept locked, so that any one visiting the place must go to our friend the keeper for the key, and he always accompanied them. Thus we had an arrangement with him, that he should give us warning of his approach, so that we could shut our door, and keep quiet until they had gone again. On our second day there, we had a fright. Towards evening, the oil for our cooking lamp having run short, Miss Gregg and I ventured into another building used as a kitchen, where there was a lot of sticks and dried grass, and tried to boil the kettle gipsy-fashion. While thus employed and with the door wide open, two men came by and went along into one of the temples to worshlp. They made no signs whatever that they saw us, so we, hoping they had not noticed, slipped quietly into our retreat, while they were burning incense, and remained there until they had gone again. Alas, this was the beginning of trouble for us, but trouble which our God turned into the means of our escape from death, as will be seen as I tell the sequel. It appears that the temple-keeper's mother was very ill, and he having to go off to the city seeking medical help for her his younger brother, who was not in the secret, brought up a worshipper who came along at the time; hence we had no warning of their approach. The worshipper, a man from the North suburb of the city, had seen us, and upon his return soon set the rumour afloat that the foreign devils were hiding in the temples on "Lien-hua-shan" (Lotus Mountain). 'The effect of this rumour did not reach us for a day or two, so I will go on to describe our experiences consecutively.

About midnight on this day, Saturday, July 7 th, our cook came with two inquirers, bringing us provisions and new's which filled our hearts with dismay; it would have been despair, but we had our Heavenly Father with us, and through this and all our subsequent trials 
we have realised His constant and keeping power. Our house had been looted by the rabble that day, and we were now practically homeless. This not only meant the loss of our all, but also the belongings of Miss Gregg and our fellow-worker, Mrs..Cameron, who was away in Chefoo. The Master had given us an opportunity to take joyfully the spoiling of our goods for His Sake.

It seems that after we left, the servants thought it well to gather the things together as much as possible, and even went so far as to remove several boxes, under cover of darkness on Friday night, and deposited them in their homes. On the Saturday morning two of them went next door to interview the landlord. They told him we had gone away for a time, and asked his help in keeping the place intact. Upon this, the landlord, professing to be in full sympathy, came round to our houses and at once advised that they should completely clear the three dwelling buildings of the main court, stowing away the things in the two rooms through at the back, the idea being to throw the place open to any who might come about, when word of our flight got round, and let them see that we had really gone and the place was empty. So they set about the work, our three men, the landlord, his brother and their partner. All our foreign padlocks were removed from the doors and some considerable amount of stuff was already stowed away at the back when one suspicious character after another began to arrive. Thicker and faster they came, and the affair soon developed into a general riot, every one making off with what they could lay hands on. The whole thing was planned by the landlord; he had been on the roof the night before watching our men removing the things. Now he locked the two back rooms with his own locks, ordered off our servants and would not let them touch another thing. At an ordinary time this could not have happened, but if it is understood what a state the country was in, what an anti-foreign spirit there was abroad, how the news of the wholesale murder of foreigners and the destruction of Mission property was rife, how the Boxers were doing their terrible work under the patronage of the Dowager-Empress and a certain party of the Government, how the officials were all afraid to show favour to foreigners and quite unable to give them any protection, then it will be seen what an easy matter it had hecome.

The mandarin, who would know quite well what was going on, took no step to prevent it. Some may wonder why I had not sought his protection instead of ourselves finding a place of retreat, and why I left without letting him know, but since my last communication with him the Government had taken a step which effectually prevented the officials from in any way defending or befriending foreigners. The Boxers had been officially recognized by the Peking authorities and some of their leaders promoted to the highest ranks and grades. They were now being used with the regular army in the effort to exterminate all foreigners and check the advance of European forces at Tientsin. Knowing this, I thought it no use to make his position more difficult and run the risk of its getting abroad that he refused 
to do anything for us. Now, however, I was led to go to him, as privately as possible, to see if he could do anything for us, or at least get his advice, which I felt would be friendly. I impressed upon the servants and the two inquirers who brought the news the importance of finding a more permanent and safer hiding-place, where if possible we could remain until this trouble was past, feeling that this state of things could not continue long. To move far away was out of the question as the districts all round were worse than our own immediate neighbourhood. Sunday, July $\delta$ th, was a day of much sadness and perplexity, but again we proved the promise "They that wait upon the Lord shall renew their strength." Towards evening I set off for the city, but, as I had anticipated, the mandarin was powerless to help me. He did not even come into the room to see me, our conversation being carried on through the Secretary who had been to our house twice. Explaining why he could now do nothing for us, he asked me to remember what he had done a week or two previously as an indication of what he would do if possible. He too was afraid of the Boxers. Several officials known to have proforeign tendencies had been lilled by them, and already a report was about that he had taken a bribe of Tls. 700 from me. If I could myself find some hiding-place away in the mountains for a time, it was the best thing that could be done under the circumstances. $\mathrm{He}$ sent a strong guard of underlings to escort me out of the city and help me to get quietly away again. An enormous crowd had gathered outside the Yamêm when it became known that I was there, but we gave them the slip. The few score who gathered at our heels before we got to the city gate were held back there by part of the escort and I was able to get away without any molestation, arriving at the Temple about I I p.m. By the next day, Monday, July gth, the report that we were living at "Lien-hua-shan" had reached the village near, which really had control of the mountain and its temples. There was quickly an uproar: the big gong was beaten round the village to call the inhabitants together. A council was held at which it was decided to send a representative to see if we were really there, and if so to order us off at once, or they would come that night in force and turn us out. About 3 o'clock this man arrived at the Temple in company with one of the priests. We were resting at the time and were suddenly alarmed by the sound of footsteps. The priest showed more or less kindness, but the man from the village was a real bully, and looked as though he would like to lay hands on us then and there. I quietly assured them that I would gather our things together and go at once. They then left us and we were face to face with the fact that go we must; but where?

Our first impulse was to turn to our Father, and we poured out our heart before Him, the "God of deliverances;" then with trembling faith, looking to Him to open a way, we set about packing up all we now possessed of this world's goods. We could not communicate with our friends in the city, and as for the Temple-keeper, who had promised to visit us daily, we knew not what had become 
of him, as we had seen nothing of him since our arrival. Having the two children to carry, we knew but little else could be taken with us, and not knowing where we might get the next meal we were all just trying to choke down some food when the keeper himself arrived. He first told us why he had not visited us; his mother had died the day before, and he had been unable to leave her. Since then he had been making funeral arrangements. The priest had proved his friendliness by going at once to him, telling our position and urging him to try and help us out of it. IVe knew that our prayer was answered as soon as we saw him coming, and our hearts overflowed with thankfulness to God as he said, "Don't be afraid, I have another place for you; it is a natural cave high up on the face of this mountain; plenty of room inside but a very small entrance; very few know of its existence; you will be perfectly safe there until they can find you a better place."

Shouldering a giant's share of our things, he then led the way; we carried a load, and dear Vera trotted alongside over the difficult stony pathway. The last 300 feet was a steep trackless climb, and the children had to be carried up, but after two or three trips we were all sitting breathless in His own "Cleft in the rock." Promising to go to the city next day, and let our servants know where we were, and indicating a spot right away down at the foot of the mountain where I could get water, he left us. On inspecting our new home we found how damp it was; only one small place on the ground, 5 feet by 3, seemed really dry, and here we spread our bedding-bag. Certainly it was beautifully cool, after the intense heat outside of the hottest month of the year, but we realised how injurious to health any prolonged stay there would be.

It was now about 6 p.m., and we partook of some food, the children asking piteously for a drink. We could only promise that they should have some water as soon as it was dark enough for father to go down and fetch it.

The last words on little John's lips as he fell asleep were "I'm so thirsty." About Io p.m. I ventured to creep out and climb down to the stream; unfortunately none of our utensils would hold more than about a quart; so taking a kettle and small bucket I made a successful trip, finding that it was quite as much as I could manage to climb up with. After a rest I made a second trip and secured enough for our needs the next day.

When the news reached the city next day that the village people had turned us out of the temple, our servants and friends were filled with dismay. Not having the least trace of us, they could only guess that we had not gone far owing to the children and the effects. So five or six of them set out and searched nearly all day in every nook and cave they could find. When the man went to the cook's house to tell him our hiding-place, he, poor fellow, was out searching for us and the messenger dared not leave word with anyone else. The search party had separated in order to cover more ground, and some remained until dark in their vain effort to find us. One of them, an inquirer, 
met a gang of eight or ten armed men who said, "Are you looking for the foreign devils too:" Others of the party had seen the same gang, and later on we learned they were a band of Boxers. The Governor of Shansi had only travelled some 20 miles from 'T'aiyuen-fu, his capital, when he was recalled on urgent business, but the troops and Boxers had come on and arrived at Huailuh that very day. Hearing that our house was empty, and that we were hiding on the "Lienhua Shan," a party of them tried to find us, and even searched the temple we had left the day before! We were hidden alike from friend and foe, for when He hicles none can find till He Himself show the way. This was the first of our wonderful deliverances from death, for they certainly would have killed us had we fallen into their hands.

Late in the afternoon our cook returned to his home tired and hungry. When told that a man of a certain description had called to see him, he knew it was the temple-keeper, and it flashed upon him that in some way he knew of our whereabouts; so, only waiting to get food, he set off again to the keeper's home, who about Io p.m. brought him along to our hiding-place. What a meeting! How we praised God together! The lad had carried with him a big stone bottle of Chinese tea and some eatables, and also the good news that on the Monday he with our servant had been into the country and found out what seemed to be a splendid retreat for us. It was too late then to arrange for our removal that night, but he promised to come the next night, with three or four others, and help us move to our third home, about three miles away. The two days spent in this cave were truly a trial to our faith. After sleeping the one night there, we all feit the cold; chilled to the bone we sat huddled together covered with rugs; our food supply was very meagre, in fact by mid-day on the Wednesday we had very little left. But the God who sent the ravens to Elijah sent us a feast of unleavened cakes and cucumbers by the hand of a man who had at one time been in our employ; his village was near, and he was friendly with the templekeeper. Succeeding in learning from him our hiding-place, he brought these cakes, just when we were feeling very hungry, and offered to take us into his home if we would go. Picture the little company sitting round in that dimly-lighted cave, a dough cake in one hand and a cucumber in the other! I assure you we needed not to pray "for what we are about to receive make us truly thankful"! The children especially felt the restraint of these two days. Ve dared not let them speak above a whisper, for there were shepherds with flocks of sheep on the mountain side nearly the whole of the time. With thankfulness too deep for words, we welcomed our relief party who, with us, could hardly keep back the tear's of emotion and joy.

Six men came so that we might be relieved from every burden. With Vera on the back of one and John asleep in the arms of another the long single file moved on. A bright full moon made the progress casier, though not so safe, and all were very glad when we reached the place about I.30 a.m., without having been seen by any one. 
We found a nice clean little room prepared for us, such as one rarely sees in a Chinese farm-house. 'The principal value of this place as a refuge was the fact of its standing alone, the nearest village being a mile away, and hidden from view by hills. These single house are very rare in this part of China. The household consisted of Mr. Kao, his wife, two little girls, and his elder brother. Arrangements had been made that they should cook for us, it being impracticable for us to have anything but Chinese food now. Recciving us very kindly, our landlord assured us that he intended to take good care of us and nothing should be left undone that could possibly lessen the trials of our imprisonment there; although we found out afterwards that he did not know the seriousness of our position. A splendid watchdog was an additional advantage. No one was allowed to get nearer than hearing distance without there being a vigorous warning. So here we have a house alone, completely shut off on all sides by mountians, out of sight and hearing of the nearest village, and a clean room; a strong-minded landlord, respected and feared by all the near villagers; a clean woman who could cook Chinese food admirably, and two little children about the same age as our own, whose laugh or cry would be a set-off against any similar noise our bairns might make; a good watchdog, and a household of one mind to keep the fact of our presence there a secret.

Surely this must be owned as the Lord's provision for us. There were disadvantages, however, for the hillsides all around were terraced and under cultivation, and this being a busy time on the land our court-yard was overlooked all day. Thus we were obliged to remain in the room and could only take air and exercise after dusk, when the toilers had gone over the hills to their villages. The well, too, being the only one in the valley, was constantly used by those who were working on their land, and only a very thin wall, through which the slightest sound could be heard, separated this well from our room; thus many times a day we were obliged to keep perfect silence. Then, again, they often came to borrow some implement, or to chat with the landlord; and although he did his best to get rid of them quickly, all this tended to make the restraint under which we were placed more trying and difficult.

It was here, however, that for the next four weeks we learned many precious lessons from our Master, and enjoyed much of His loving kindness and fellowship.

On the night following our arrival, two of our men came to bring provisions, and a reply telegram from Shanghai, in which anxiety for the safety of our station was expressed, and for that at Shuenteh. I had to reply that both stations were already rioted, and gave some idea of the danger and difficulty of our present position.

Very few nights passed, especially during the earlier part of our stay, without our men coming either with provisions or news of some kind; and though daily we hoped for an improvement in the situation, things seemed to go from bad to worse. Not very long after he had got rid of us, the landlord of our house in Huai-luh, now under his true 
colours, invited a teacher of the Boxers to the place, and soon a school of some twenty men and youths were in full possession of our premises, learning the mysteries of "Boxerism," which is the art of becoming invulnerable to knife or bullet and a fit subject to be possessed by demons. Fron time to time we heard of different Mission sations being destroyed. Through the kindness of the clerk, I kept in $\mathrm{t}$ uch with the telegraph office, though the wires were repeatedly cut in both directions. A message I sent to P'ingiao, one of our Shansi stations, was returned after nine days' delay with the words "No receiver" on it. This, with the terrible rumours of what was taking place in Shansi, although we could learn nothing definite, convinced us that the awful persecution was spreading in that province also, and lept us constantly in prayer for our friends there.

Again, as though to add sorrow upon sorrow, some of those who had helped us in our exile, falling under the temptation of the evil one, sought to gain advantages to themselves at our expense and serious injury. Sicliness too came to test us. Miss Gregg had a very bad attack of dysentery which lasted about a week.

My dear wife passed through nearly three weeks of great suffering with abscesses in her ear, whilst 1 myself was troubled more or less with neuralgia and indigestion nearly the whole time. Only the 1.ord Himself enabled us in the midst of so much suffering both of body and mind to bear the constant strain of answering and quieting the dear children.

The messenger who first brought word of the rict at Shuen-teh Fu had promised to return within a fortinght and let us know how our friends, Mr. and Mrs. Griffith and Mr. Brown, fared; but as time passed there was no news of them, and we were thinking of sending to inquire, when we were startled one night to hear from our cook that they were in Huailuh, having arrived the same evening. After spending a fortniglit in the momtains, they were turned away by the villagers, their money was all gone, and being practically destitute they walked back to Shuen-teh Fu in the night, and demancied protection from the chief official there. He promised to escort them to a place of safety and was sending them through into Shansi. Had there been time to get there and back before daylight, I would have gone to the inn to see them, but we could only send them a few of our things with a letter of sympathy, and follow them with our prayers as we heard of their destitute condition and the iil-health of Mrs. Griffith and her baby. The dread uncertainty of their destination, and the fear that in groing west they were only groing from bad to worse, seemed almost more than we could hear. Four days later, as a further surprise, word came that they were again in Huailuh. It appears that when they reached 1 "ingting Cheo, about 70 miles away, the official there would not allow them to be sent back to Shuen-teh. He told them that Mir. I'igot of the Sheo-yang Mission, 30 miles further on, had been killed by Boxers, and that it was almost certain death to proceed. 'This was indeed the Lord's deliverance for our friends, and we praised Him for it. On arriving at Chengtingfu, 20 miles east 
of Huailuh, Mrs. Griffith was very ill, and as to continue travelling by cart seemed risking her life, they decided to accept an invitation to go into the Roman Catholic Mission there, which was still untouched, thus we were able to correspond with them and know of each other's welfare.

With the third week of our stay at the farm came a new trouble. It began to be whispered abroad in the villages that we were there. This led our host to prepare a place for us in case of emergency. By cutting a passage way through the cliff that the house was built against, he joined one of the smaller rooms off the kitchen with two tumble down caves at the back of the building, which had once been used as dwellings. I eaving only a very small entrance on the house side, and no one but ourselves knowing of its existence, it could easily be concealed. The doors and windows of the caves were walled up, only leaving a very small hole to admit a little air and light, and the only means of entrance was by the secret passagre from the kitchen. With but a very short warning, we and our belongings could all be hidden, so that anyone searching the place would search in vain. But of course the caves were too damp and dark for us to stay any length of time there. Even with this additional security, we thought it advisable to seek another retreat. One of our inquirers urged us to go to his home, about 40 miles south, and we had a very warm invitation from the R.C. Bishop at Chengtingfu to join the friends there. It was on Thursday morning, Aug. 10, while we were in the very act of talking about these two offers and seeking to know our Lord!s will for us, that the decision was suddenly taken from us and we found ourselves in the hands of a band of armed Boxers. Warning was given that several men were approaching, and we quickly hid ourselves in the cave, while the woman covered the entrance with household chattels. The inquirer mentioned above. Mr. Keng, who was there at the time, joined us in the cave and listened near the opening so that we might know what was going on. Soon the tramping of many footsteps and loud altercations could be heard. Mr. Keng came to tell us in awed whispers that a number of Boxers were searching for us.

We felt that, if they had any reliable information that we were there, they would soon intimidate the farmer into revealing our hidingplace. Escape was hopeless. We were walled in securely; the only exit there was was through the house now being looted and searched. Looking up to our God, whose own peace garrisoned our hearts, we waited with bated breath to hear if they should discover the concealed doorway. The footsteps came nearer, the voices grew louder, there was a banging of utensils, then a short of triumph!

With one voice we lifted up our hearts crying, "Thou art worthy." We thought of the dear children whose piteous queries, "Will they klll us?" "Are they going to kill now?" pierced deeper than any Boxer's knife, and we told them that very soon we should be with Jesus, and I was led to go out and plead with these men for the lives of the ladies and little ones.

Groping my way along the passage, I stooped and lifted the 
curtain which covered the hole and was just creeping through when one of them fired at me. By the dull heavy thud on my head I knew I was wounded, and was conscious of falling through the entrance, then rising to my feet I seemed to spin round two or three times in the room, then I leaned against the wall for support. As I did so, I saw through the open door several Boxers run across the court-yard and heard one shout, "All get outside and on the roof." The blood was now streaming down my face, but clearing my eyes with my handkerchief I saw one of them on the roof opposite just firing at me. It was an old flint-lock and just flashed in the pan and missed fire. Then two others appeared further along on the roof, armed with guns, who sought to aim at me through the windows and doorways as I staggered from room to room, scarcely knowing what I was doing. I think I was looking for a way of escape.

Then I made my way back into the cave and said to my wife, "They have shot me in the head, dearie; 'tis certain death for us, only a matter of time now. WVe are not worthy, but He is worthy." Soon after, Mr. Keng left the cave. They knew they had us safe and had not been watching the entrance, and as they did not know he was with us he managed to conceal himself in one of the other rooms and escaped when all had left. Fearing we might be armed, they dared not venture into the dark unknown passage, and now we heard them battering in the recently walled up doorway of the cave from the fields outside. Some few bricks were removed, letting the full light in upon us, and we retreated into the darkness of the second cave. Then the battering ceased, and soon the farmer himself came through the passage and joined us. Poor fellow! his face was a terrible picture of fear. He told us how they had robbed the place of everything movable worth taking away, and now threatened to set fire to the house unless he could persuade us to come out of the cave. They promised not to kill or injure us in any way, but would take us to the local Magistrate and let him do what he liked with us. This was so far removed from any known Boxer policy that we were sure it was only a ruse of the farmer to save his property. To die in the cave or outside in the yard was all the same to us, and if the man's house could be saved why should we prolong this terrible waiting? So we sent Mr. Kao to tell them that we would come out into the yard, and, after briefly committing each other to our Faithful Creator, made our way through to the litchen. Not a soul could be seen through the open doorway, but as I stepped on the threshold I saw a man standing on each sicle against the wall, with their huge ghastly swords uplifted. Stepping back for a moment to tell the ladies to be prepared, I walked out with one of the children in my arms, the ladies following with the other child.

We were immediately seized and those great knives brandished over our heads. Then the word was given, "Bring them round to the back," and they dragged us out of the court, round the buildings and up an embankment leading on to the flat roofs of the north rooms. Here, without releasing us or re- 
moving the swords from our necks, they demanded to know what things we had and where they could find them. Seeing the distress of the children they told us to tell them that they would not kill us. Having secured all that was left of our clothing, bedding, etc., they proceeded to search our persons, even to the tearing off of my wife's wedding-ring, keeper and spectacles. 'The only thing Miss Gregg had with her was a small Bible which she was led to slip into her pocket as we left the cave. It was examined by two or three of them; then, although divided in opinion, the leader handed it back and said she might keep it, adding, "If you read that you can get to heaven."

Thus our gracious God made provision for His children, and this little treasure, positively the only thing we now possessed beyond the few clothes we were wearing, has been an untold help, blessing and constant comfort to us through the rest of our trials. "I have esteemed the words of His mouth more than my necessary food." Once on a later occasion it was taken from us, but He prevented its destruction, and after six days' wanderings it was again restored.

Much to our surprise, having secured all the booty, they led us off to the city as promised, and actually hired two men to carry the children, seeing how weak I was from loss of blood and that our progress was too slow.

What a procession! The villagers had turned out en masse on the surrounding hills and saw us led away, each overshadowed by those awful knives, while those who carried fire-arms walked in the rear. About half way we met the local school of Boxers, who I suppose had not yet graduated sufficiently to take part in the more active business, but who could in this way share in the glory of taking us to the city. With them came our landlord, bringing a supply of watermelons for the loyal follows who in the Emperor's name were ridding the district of those dreadful foreigners. As I passed quite close by him he hid his face with his hand, no doubt hoping that I should not recognise him. Leaving the road leading to the nearest city gate, they took us along by the North wall towards the East suburb, and when I overheard them say they were going to our own home my heart failed me, as I felt sure it must be their intention to kill us there; once in their hands no foreigner had ever been known to escape. I knew too, from the dialect, that these men came from the Paoting-fu district and shuddered as I imagined they were probably part of the company who killed all the dear missionaries there, including our own Mr. VV. Cooper, Mr. and Mrs. Bagnall and their little girl.

There was real sympathy on the part of many in the enormous crowds lining the streets as we passed along, and among them was the tear-stained face of our own serving women, to whom Miss Gregg shouted as we passed, "We are not afraid, God is with us!"

On arriving at the familiar doorway, the crowd was held back and not allowed to enter, while we were taken up into the dining room and the door was immediately fastened. The uncertainty and 
suspense were terrible, but when they proceeded to examine and wipe their swords, I said to the ladies, "They are going to kill us now." Then word was given that all should repair to the back for worship (this plays an important part in the Boxer propaganda), and we were left alone in the room, with the door sccurely fastened. Seeing an empty bedstead in the inner room, we passed through, and were very thankful to sit down after our three miles walk in the hot sun.

What a wreck our home looked! With unswept courts, broken windows, and bare empty rooms :

The dear children were soon asking innumerable questions as to what had become of this and that. Now the door opens and a man enters, the sight of whom fills my heart with hope; he was one of the local policemen. After some commonplace talk, he managed to whisper in my ear, "Don't fear, there are several of us here on the alert, and the mandarin will be here directly."

Could it be that after all they were handing us over to the official, as they said?

The joy of life given back and reep thankfulness to God began to fill our hearts. Truly this was as a cup of cold water to the fasting soul; the fainting boly too was very grateful for the pot of water handed through the broken window by some one who heard the children crying for a drink. When the official arrived we were formally handed over to him by the spokesman of the Boxer party, now dressed up with fan and gown, and using language which proved him to be an educated man.

Without much delay we were escorted outside and a new procession formed. Besides his ordinary retinue, the Mandarin had now an additional bodyguard of about 200 soldiers who were also used as a kind of city guard, and had been enlisted on account of the troubled state of the Empire. We walked between this long single file followed by the official chair and all the underlings, through the suburb and eastern gate, to the Yamen in the middle of the city.

Thousands lined the streets, and although I was now too faint and giddy to care, this walk to the Yamen was a great trial to the ladies. The Mandarin blamed me for not having sought him earlier, that he might have sent us away before this trial came upon us? When I tried to remind him that I had sought his protection, he immerliately talked about something else. As this was before all his staff and he had his "face" to save, and as I knew how helpless he was, I did not press the matter.

He said he would send us to Chengting-fu on the morrow, hoping the Bishop there would receive us, failing which we should be escorted from city to city up to Paoting-fu, and the Governor of the Province would find some means to enable us to leave the country and return to our own land.

Having already received an invitation from the Bishop, we thought of no laoting-fu or elsewhere.

He then gave orders that a lodging should be found for us within 
the Yamen precincts for safety, and we were accordingly led off to a small temple, professedly the only available place they had.

The relief of finding ourselves really out of the hands of the Boxers, and the deep thanifulness in our hearts to God for this second deliverance from death, coupled with the hope of soon seeing our friends in Chengting-fu, enabled us to look more lightly on the hardships of our surroundings.

On examining my wounds, we found that it was a full charge of No. I shot that I had received, and owing to my peculiar stooping position at the time my head, face, shoulder, arms and back had all taken their share. As blood, hair and clothing were now firmly clotted, we decided to leave it so until we reached Chengting-fu, where I could get proper surgical dressing and treatment. I suffered terribly that night, which we spent on some reed mats spread on the damp floor of the temple. Praise God, the dear children slept, but the pain, stiffness, and dread of the twenty miles jolt in a cart the next day were more than enough to keep me from sleep. How one longed for a soft pillow for the poor wounded head, but the only one I had was a couple of briclis. Every now and then the blood all seemed to flow to my head and I was obliged to get my wife and Miss Gregg to help me up and walk with me up and down the place for some relief. We were out very soon after daylight and had not been long in the yard when dear Mrs. Liu, our woman, arrived. She had tried the night before but could not get to us, and had been waiting outside the Yamên since long before dawn, hoping for an opportunity to see us. She had been told by neighbours that we had been executed in the prison, and that we died singing hymns. Her reply was, "I do not fear, our God is with them." The interview was most touching: she took up the two children in her arms with a loving tenderness rarely scen in this people; and when leaving she embraced and kissed my wife and Miss Gregg, regardless of all onlookers. Her calm strong fäith in God and loving helpful words, with the recollection of others in our little flock, enabled us to share St. Paul's joy when glorying in his Corinthian converts. "I am filled with comfort, I am exceeding joyful in all our tribulation." Returning home she sent us a thick wadded Chinese coverlet to spread in our cart, with some fruit and cakes for the children. By about 7 a.m. We had left the city; the country was looking beautiful, especially to us after our month's imprisonment. The rains had only just come when we left our home, and the whole plain was bare and barren; now it was a picture, with its luxuriant crops and trees. When about five miles out, a new trial came to us; the band of Paotingfu Boxers ovcrtook us! Each was carrying a bundle of the booty taken, and some were even wearing our garments. Although they did not actually keep alongside, they overtook us and we passed them again two or three times during the remaining fifteen miles of the way. When we stopped for lunch at the ten mile stage, they were at the same inn also taking food. The Lord wonderfully sirengthened me for the journey and, though I suffered considerably, I was a marvel to myself and others. 
On arriving at the East Gate of the city, we saw a large crowd gathered, and several Yamen people about. The cart was stopped and the official papers concerning us handed over by our escort. Then followed a long wait while the papers were taken to the Yamen. It was early afternoon, and the fierce sun, with the great crowd swarming almost on the cart, made the heat unbearable; but there we sat, bathed in perspiration, travel-stained and dishevelled, gazed upon by a continually moving stream of curious ones for two hours. It was during this trying wait, when we expected every minute to be taken into the city and to the Mission House where we should see our friends, that the Lord gave to my wife this text, "Delivering thee from the people unto whom now I send thee"; and in the cave that clay, as we sat momentarily expecting death, was given to Miss Gregrg the promise, "A thousand shall fall at thy side and ten thousand at thy right hand, but is shall not come nigh thee." These two remarliable texis, seemingly so inappropriate at the time, were used of God through all our later experiences to keep us in the assurance that it was His purpose to save us, and over and over again He led us to remind Him of His own word.

A stir in the crowd, and way was made for a military officer who told us not to fear, we were being sent home to our own country. Then word was given to drive on to the North suburb, but still outside the city. Even yet we never dreamed we were not to be allowed to enter, but thought they feared the crowd and so would escort us to the suburb nearest the Roman Catholic Mission, and then take us there under cover of night. Once at the inn, I thankfully lay down to rest, but alas! not for long. We were soon to be undeccived, for a man from the Yamen came to say we had better hurry up and order some food, as another cart was already waiting in the yard to take us on the next stage of our journey to Paotingfu?

In vain I pleaded that we had hoped to go to the R. C. Mission, that it was certain cleath to senc us to Paotingfu where the foreigners had already been killed, and that many places on the way were full of Boxers; also that it was inhuman to send a wounded man such as I was, with two ladies and the children, without a rest, to travel far into the night. He declared that I could rest as long as I liked at the next stage, which was ouly a village, but go on we must. The officials were afraid of the Boxers who accompanied us, they too being forbidden to enter the city.

It was useless to say more. I was only talling to an underling, and we were cntircly at the mercy of these people. We ordered food and tried to take some, knowing there would be none during the next stage.

'The Mandarin at Huailuh had given me 500 cash for travelling expenses, and now they brought me 1,000 from the official here for the same purpose.

Even while getting food they came again and again to hasten us. On groing out to the cart, we found the Boxers' bundles and weapons piled on the back; and we knew that after all we were not out of 
their hands, but that although at each stage we had an official escort from the Yamen we were really in the power of the Boxers. It is useless to attempt to tell all that passed in our hearts as we got on the cart, which soon started and left the town behind. What would dear Mr. and Mrs. Griffith and Mr. Brown suffer when they heard of our passing, that Boxers were with us, and that we were being sent to Paotingfu! The Provincial Governor there had only recently issued a proclamation which declared that all foreign teachers of religion were deceivers and propagators of devilish and injurious doctrines; that all who had joined their churches must recant at once, or they and their families, man, woman and child, would be killed, their houses burned and property confiscated; that the missionaries must get back to their own countries and would be protected as they proceeded to do so. This last, as we have proved, was only an empty clause. To this man we were now being sent, barely six weeks after all the missionaries and their families had been cruelly murdered in his own city and its suburbs.

The children slept most of the way, and Fuchingi, the next posting station, I5 miles distant, was reached about midnight. Instead of being allowed the rest we were promised, we were transferred to another cart at once, and proceeded on our journey to Sinloh Hsien, the next stage of 23 miles, which we reached at daylight the following morning.

Here the Boxers brought us some millet soup and a few bread cakes, and we begged a drink of hot water from some of the Yamen men. After sitting in the cart for about an hour and a half, we were once more transferred to a fresh cart and started for Tingcheo, the next 20 miles stage. This was the place where the postman had been murdered, and all around the neighbourhood the Boxers had pillaged and burned the houses of the Roman Catholics killing every man, woman and child they could find. It seemed so improbable that we should be allowed to pass through the place alive, that our hearts were kept lifted up to God that we might be prepared for His will whatever it might be; our desire was that He might be glorified in us, whether it were by life or by death.

The cart was stopped in the street of the South suburb of the city while some of the Boxers paid a visit to a local branch of the fraternity, and of course a great crowd gathered. As we passed along, the streets were lined on either side, the great crowd following in the rear.

Arriving at the Yamen about noon, we were very glad of the quiet afforded by the little prison room into which we were taken, and we also received some kindness from the keeper. We were no doubt an object of great interest to the half score or so of male prisoners who were chained up in the large wooden cage at one end of the room.

The keeper made us tea and lent us his boy to go and buy a couple of cheap fans, and a small piece of Chinese calico for a handkerchief, as we only had one left between us. Food also was 
sent for, and we were much refreshed by a rest and the little kindness received. I suppose it would be about 3 p.m. when word came that the cart vas ready, and once more a start vas made. Uangtu Hsien, our next stop, was 23 miles distant and the road was in a very bad condition. Heavy rain had fallen, and we were ploughing through mud and water up to the axle of the cart, for a great part of the way. Along this stage we had a proper official escort, and the Boxers were not allowed to have things quite their own way, although there were ten of them. There were six horse and six foot soidiers, besides other Yamen men. The man in charge who carried the papers was also mounted. I counted $2 S$ in all, Boxers included. About sunset a heavy thunderstorm gathered, but we only caught the fringe of it.

Even that was sufficient to wet most of the men through, but we were sheltered by the matting cover of the cart. It must have been near midnight when we arrived at Uangtu. Only those who have travelled by cart in North China will really understand what this journey must have been to us, pracícally without a rest, day and nignt, for forty hours. God most certainly gave the strength and grace, or no ladies could have taken such a journey, to say nothing of the children and one wounded as I was.

A shake-down was made for us on the floor of the prison room; first a spread of straw, then a reed mat, over which we spread our coverlet. The official's head man and others with him were moved to pity to see little John, as soon as the bed was ready, get down from my knee, crawl along on to it, stretch himself out full length and immediately fall asleep.

There was a prisoner in the cage at one end of the room, and five or six men slept on the brick bed at the other. But we were too far gone to care for these things, and lying down all in a row were soon fast asleep. Neither the ladies nor I had slept since the previous IVednesday night, and this was the small hours of Sunday morning. On rising we were able to have a wash, the first since we left Huailuh. Then the head man came along to say that a train of one carriage and engine was running daily the 30 miles to Paotingfu, our last stage, and that arrangements had been made for us to go by it, as the roads were in such a bad condition. He also spoke encouragingly to us, and told us that the Emperor had issucd orders for the protection of missionaries.

About 9 a.m. we left the Yamen for the station. Alas! there was a hitch somewhere, fo: as we came in sight the little train moved off. No one quite knew why. Some said the driver had left word he would be back soon, other said that he had gone for water. After waiting more than an hour in the hot sun, we moved on about half a mile, to wait under the shade of some trees by a temple. A messenger went to the town to ask a few sellers of catables to come along, and we were soon refreshed by watermelons and dough cakes. It was a long weary wait sitting on the cart, but later the ladies and children were allowed to get down and sit in the shade on the grass. Hour after 
hour passed, until at last about 5 p.m., word was given that we must go on by cart. This meant travelling all night, and 30 miles more of that awful jolting over bad roads. Again His grace was sought and given. The next thing to look forward to was a rest and some food while the animals were fed at a place ten miles on the way. Here we had a nice supper and the children got a little sleep.

Then, leaving again about midnight, we arrived at Paotingfu Aug. I 3 th, soon after daybreak, the city gates being still closed. As we waited there for the gate to be opened, it seemed to us that we understood as never before something of what our Lord must have felt as he went up to Jerusalem. Very soon we were able to enter and were taken straight to the district Yamen. Alighting from the cart, almost before I was aware of what was happening, we were separated, the ladies and children being taken to the women's lock-up, and I was marched off to the men's common prison. I found myself in a filthy yard with some twenty prisoners in various stages of dirt and wretchedness. Spreading my coverlet on the damp ground, I lay down and cried, not for the ignominy heaped upon me, but the thought of being separated from my dear wife and children at this time was unbearable. Perhaps I had lain there about half an hour when I heard a call for the "foreign man." Some one had been sent to fetch me back to the cart, which was still standing where we left it. I was rejoiced to find the ladies and children already there, and looking refreshed for the hair-combing they had been able to get through the kindness of the female prison keeper.

They told us at first that were to be taken on to the Governor's Yamên, but a little later I learned the truth, that the district magistrate had refused to receive either us or the official papers concerning us, and intended to send us back at once to the place we came from.

A fast increasing and excited crowd was surging about the cart, and a number of the city Boxers appeared with their guns and great swords and took up their position all around us. Not one of the Boxers or official escort who had brought us were to be seen. The heat became intense and we sat like that for at least two hours.

On first rejoining the cart, I had heard the spokesman of our Boxer party say, "There will be trouble here very shortly." To that man, under God, we undoubtedly owe our lives on this the third wonderful deliverance from death. He had gone to the Mandarin and pleaded for us, showing him that we should certainly he killed as soon as we got out of the city, even if we were allowed to get that far. Ultimately the official had relented, and gave orders that we were to be received into the Yamen and he would see what could be cone with us. So it came to pass that, with some considerable shouting and husting, a way was made through the crowd for several underlings, who again took us off to our respective prisons. I had only been set down five minutes, when I was again called out and taken to have an interview with the Mandarin himself. He spoke kindly, professed sympathy with us in our distress, declared that the western Powers, 
including my own honourable nation, were to blame for the present state of things, having "rebelled" against the Government and taken Tientsin, but since we had come to Paotingfu, they would devise some means for protecting us. I asked as a favour that we might all be together no matter where it was, so he gave orders that a room in the women's lock-up should be cleared for us, and I was taken off to join the ladies and children there. The joy of finding ourselves together again, and the reaction after the tension, were too much for my now weakened body, and I could only lie down and cry.

It was a nice and fairly clean room we had; two women were in charge, and they went out to buy anything we needed. And now, taking this the first opportunity since I was shot, my wife and Miss Gregg set about cleaning rny wounds and seeing what could be done to remove some of the pellets. With the aid of a broken-pointed penknife (found in my wife's pocket a day or two after our capture) and a needle, five or six were extracted, and at different times Miss Gregg has succeeded in getting out several others, but many were imbedded too fast and must wait for proper surgical instruments. Though troubled much by mosquitoes, we had a fair night's rest, retiring early and rising late.

The next day, Tuesday, Aug. I4th, about 10 a.m., one of the Yamen men came to say that arrangements had been made for us to be taken to Tientsin by boat, and that we were to start that day! Such a lot of running to and fro from one official to another had been going on all night about us, and everybody had been "troubling their hearts" and planning for us, with the result above mentioned.

The Mandarin sent me $\mathrm{I}, 000$ cash for travelling expenses; his son who came to see us, moved to pity, sent another I,Ooo. We were advised to procure what we needed for the journey before starting, so that no risk should be run by stopping to buy on the way. By travelling day and night we should probably get there in 48 hours, with the strong current in our favour.

At 3 p.m. two carts arrived to take us to the riverside, and we were officially sent off by the Mandarin's head man and several secretaries, \&c. On arriving in my own country, I was told to be sure and tell our Emperor that the Governor of the Province at some considerable trouble had sent us home !

Twelve runners with gowns and dress hats went before the carts, while several Boxers with drawn swords also acted as escort. Arriving at the riverside we were soon in the boat. Eight of the Boxers who brought us from Huailuh then came on board, with four or five of the local men, and in a little while we were making good progress down stream.

It seemed too good to be true that we should so soon be in Tientsin and our troubles at an end. Yet our God had worked so many miracles on our behalf and we knew He was able to do this thing also. Yet, I am afraid there was some misgiving in our hearts when we saw that there was no official representative in our escort. Three miles out, the local men left the boat and we went on far into the night, 
anchoring in midstream for about two hours to give the boatmen a rest, then on again long before daylight.

Soon after sunrise we were passing a walled city which I remembered was thirty miles from Pao-ting Fu.

A little later, while in the act of eating our humble breakfast of dough cakes and apples, the boat stopped and was moored to the bank. Saying something which I did not quite understand, the spokesman and the leader went ashore together.

My wife cried, "O Charlie, something is wrong ; do ask the other men what it is." I spoke to one of them, but he only wrung his hands and said, "This is terrible! terrible!" Then the two men returned and the leader said, "It is all a lie about your being taken to Tientsin ; it is impossible to get there. The river is held by Boxers at several points on the way down, and it would be certain death for ourselves as well as for you to attempt to get through. Our orders from the Governor were to bring you so far down the river, then kill you and put you out of the way." As he spoke he pointed to his long ugly knife, which I had seen him sharpening since we left Pao-ting Fu. Then he went on to say, "We don't intend to commit such a sin ; we have no quarrel with you, but you must leave the boat now and make the best of it for yourselves." "They advised us to go just over the bank, which was a public pathway, and hide in the tall reeds until evening, then go west to the city we had just passed, and see what the Mandarin there would do for us. They also told us that it was our landlord at Huailuh who had sent for them to come, and we knew that he had said that, if he could get rid of us, his house, which is morgaged and which he cannot redeem, would again become his.

Protest was useless; we were simply stunned and as if in a dream. Gathering together our few belongings, the bedding, bundle of food, and the cloth containing our cash, part of which we left as too heavy to carry, we took the children in our arms and went ashore. Getting quickly over the embankment, we were soon out of sight among the reeds and thick undergrowth, without having been seen by any one. Making sure of being completely hiden from any who might pass along, we spread out our bedding and sat down to think and pray. Both were difficult for a time, until we had somewhat got over the shock of this sudden turn in our affairs. Slowly we began to realise that for the fourth time our God had delivered us from a cruel death, touching even the hearts of these Boxers for us, and especially, I believe, for the two dear little children. All the way from Huailuh we had maintained a quiet, respectful demeanour towards them and they played with the children, often buying them fruit, cakes, etc. Many times during the days of our hiding in the temple and cave, and at the farm house, we had said how much easier it would be without the children, but in our late experiences the Lord has undoubtedly used the children to move the hearts of our enemies, giving us favour in their eyes; thus reproving us for murmuring about them.

Only one of the Boxers, the leader, had kept himself aloof all along - a big, brutal looking man, whose face will ever live in my mind. 
It was he who shot me, and I feel sure that it was since leaving Paoting $\mathrm{Fu}$ that he had been made willing to let me escape. Tears came into the eyes of the spokesman, when, on stepping from the boat with John in my arms, I turned and putting my hands together in Chinese manner thanked him. We have been convinced that without a Boxer escort we should never have reached Pao-ting $\mathrm{Fu}$ in safety; those whom we passed on the way would certainly have attacked us. They have a kind of "honour among thieves" that one company docs not interfere in the affairs of another. Why those who captured us persisted in bringing us so far from Huailuh, unless their original designs had been over-ruled by God, we can never" tell. "Blessed be the Lord.

who only doeth wondrous things."

But to return to the little band of refugees hiding in the reeds. What a day that was! Most of it spent in prayer. At every sound of footsteps on the bank we held our breath. Asking my wife what the Lord was saying to her, she replied, "I still have my text, "Delivering thee from the people. . . . unto whom now I send thee." Miss Gregg's answer to the same question was, "I have been waiting all day for a little bird to bring us a letter !"

We laughed at the time, but you will hear more of this "little bird" later on. What should we do? Knowing that we were in the very heart of the Boxer country our position seemed so hopeless. Could we by offering a large reward persuade some passing boatman to conceal us under the hatches of his boat, and attempt to get to Tientsin that way? It was less than 100 miles, and down stream might be done in about 30 hours. After praying for some time over this plan, I crept back over the bank and hid myself in the reeds on the river side, to watch the boats as they passed, hoping if I saw a likely boatman to hail him alongside and make the offer. I was soon convinced how useless it was in the daylight to attempt to clo such a thing without being detected. There was a constant passing to and fro along the bank, and the boats on the river were so numerous that I linew I could not hail and speak to one without being seen by many others. Listening to make sure no one was coming, I made a dish orer the hank, and as I did so saw two men approaching.

Knowing I had been seen, I stupped until they came up, then giving them a Chinese "Koh-t'ou" I briefly told our distress and asked their help. They were sympathetic friends in affiction, being refugces from Tientsin, but of course they were unable to do ainything for us. Promising not to tell anyone that they had seen me, they passed on, but not before a youth going in the same direction came by, who with a scared face gave me a wide berth.

I must have been an object, with dirty blood-stained undercoat and trousers, no gown, worn out shoes, unshaved, wounded face, and dishevelled hair of six months, and I had lost my quetie : No wonder he was frightened. Rejoining the ladies, I exprained that we must wait till dusk, when there would be fewer boats and people, if we hoped to carry out that plan. About the middle of the afternoon we heard the tramping of many feet and voices along the bank. IVe 
knew it was a band of Boxers looking for us by the shouting and shooting off of guns into the reeds. In about half an hour they left and all was quiet again. IVe were terribly bitten by mosquitoes, and all day long the children were pleading for a drink. IVe too were suffering much in the same way; but, apart from the risk of going to the river to fetch water, I had nothing to bring it in. By about 6 p.m. they were so distressed that I took their two little straw hats, one inside the other, and made a dash to the river and back without having been seen, but, alas! although I ran all the way, only a few drops remained when I reached them, just enough to wet their lips.

When it was quite dark and everything seemed quiet, we all went to the river side and quenched our thirst from the straw hat drinking cup. And now by the repeated lightning and gathering black clouds we knew a storm was appoaching. I hailed several boats, but not one would stop, all no doubt fearing we might be robbers, for this was a time of anarchy and lawlessness, especially in the country between Pao-ting Fu and Tientsin. All around was weird and black, with constant lightning and distant thunder. We returned to our place among the reeds, hoping the storm might pass over without rain. Then came the fierce wind bending the reeds low to the ground, and very soon the rain began to fall. A reed is at any time a poor thing to trust in, but never take shelter from a Chinese thunderstorm in a bed of reeds !

Covering the children as much as possible with the bedding and our straw hats, we sat through those miserable two hours; all were very soon wet to the skin and chilled to the bone. Oh, Lord, was there ever a more heipless, hopeless desolate band of Thy little ones? The rain ceased, so leaving the now sodden bedding and the dripping reeds we made our way to the bank where we could warm ourselves by walking up and down. TVe were all very lightly clad, having only the few thin garments we were wearing when surprised by the Boxers at the farm. The chidren each had a little bodice, knickers, and cotton pinafore, and shoes without socks. The ladies each had trousers, vest, and a cotton "liuatsi" or upper Chinese garment, without skirts, which the Boxers had taken, while I had the two garments, trousers and "likua" or undercoat. Some course of action must now be decided upon. To the east about a quarter of a mile was a riverside hamlet, and half a mile to the west was the city. Which way should we go? Perhaps influenced by the advice of the Boxers, certainly guided by God, we decided to go west and made our way towards the city. About half way there we came to a cottage, and seeing a light in the winclow I said, "Let us ask them to help us." Making our way towards the back, we saw a youth crossing the yard carrying a light. Telling him who and what we were, we asked him if he could help us to get a boat. He was distressed at our pitiable conclition and talked of the wicledness and cruelty of the Boxers, then he said he would go off and see if he could persuade a friend of his to take us in his boat. Could it be that Lord had guided us to the very one who was willing to help? We knew that He was able for this 
also, and had $\mathrm{He}$ not reminded us of the promise, "For six troubles I will be with thee, yea in seven I will deliver thee." So encouraging each other in Him we took shelter under a tree, as the rain had begun again, and waited the man's return. He was not long away; his friend was sleeping in the city that night and the gates were closed, but he had called up another man who had a boat and who would be along direcly. Inviting us into the house he got water and offered us melons to eat. We were glad to put down the tired children who soon fell asleep on the brick bed, while we ate one of the dry cakes we had - with us.

Suddenly we were startled by an unearthly sound in the yard outside; it seemed a combination of a hiss and a growl. WVith a slash of a drawn sword the reed curtain at the door was dashed down, and we were again face to face with a crowd of fierce Boxers. "Betrayed!" was the first thought that flashed through one's mind. The next moment all was confusion. I was seized by the hair, dragged to the ground, and was consicous of blow after blow on different parts of my body, then of being trampled on by many feet as others rushed over me to seize my wife and Miss Gregg. I remember a pang as I heard the heartrending shrieks of the children, and then a sweet calm filled my soul and I committed my spirit to God. Comparing notes since we have each been able to testify that this was the calmest moment in our lives so soon to be given up to Him, we never doubting for a moment that we should immediately be killed. With joy my wife accepted this fulfilment of the promised deliverance, that it should be into the Father's presence.

Now we were dragged outside and thrown in the mud, and bound hand and foot, they using their feet as much as their hands to get our arms and legs into the position they wanted, though we were quite passive. Then I suddenly missed the cries of the children and was glad that the lambs had "gone before " and were spared more of these terrible sights. Miss Gregg was hauled by the hair into a kneeling position and her head pressed down on to a stone table in the yard, used for burning incense, and one cried, "Who will strike?" But other voices overruling cried, "No, take them all to headquarters first." As we lay there bound in the mud, one and another struck us heavily again and again with the backs of swords or the handles of spears. Miss Gregg now lay close beside me and, as blow after blow fell upon her, no sound escaped her lips, only a long deep sigh.

I could not see or hear my dear wife who had been dragged some distance away. IVord was now given to carry us off; the handles to two spears were put through my left arm, two men taking the ends on their shoulders, and I was taken off hanging between them by one arm, with hands tied to my feet behind me.

It was only about a quarter of a mile to the temple building they used as headquarters. I should have fainted with the excruciating pain, had it been much further. On entering, my face struck heavily against a large earthenware water tank, and the next minute I was thrown down in the court yard. Hearing the dear children cry, I knew that 
t'ey had been brought off at once, and not killed as I supposed. My wife and Miss Gregg were carried in a similar way, the former suspended by both hands and feet, the latter by one arm and one leg. Little John was tied hands and feet and carried, while Vera with hands tied behind was made to walk, having her feet bound when they got there.

Now all had arrived and there was much rejoicing and mutual congratulations that these "devils" had been captured. Presently a tall young man arrived who by his authoritative voice I soon knew was recognised as a leader. He came and put a brick under my head for a pillow and spoke encouragingly to me, telling me if I had anything to say not to be afraid to say it. I requested that if they intended to kill us they would do it quickly and not let us go through any unnecessary suffering. Being questioned as to whom we were, I explained where we were from and how we came to be there, but they would not believe a word I said. I suppose it must have been a strange unlikely story to them, as they were convinced we came from a neighbouring Catholic Mission against which they had a special hate, two of their townsfolk having recently been killed in an attack on the Romanists there. Later on they lifted me up and gave me a stool to sit on, that I might be better able to talk to them. In my new position I could see the ladies, and at my request my wife's head was moved out of a pool of dirty water, and Miss Gregg's hands were loosened and tied in front instead of at the back, a favour they would not grant for myself until next day, though I suffered intensely because of the shot wound in my left arm.

I was soon too faint to sit up and was glad to be laid down again on the wet ground, now so near the others that we were able to whisper to each other "For Jesus' Sake." Vera too seemed to understand and in her turn sought to comfort her mother by kisses and saying, "Poor Mother! Poor Mother!"

They could not pacify the childen who had been carried into the house, so at last they let them come out to their mother, and one after another they tottered with bare feet, their shoes having been taken from them, and sitting down on the wet ground buried their heads on their mother and sobbed themselves quiet. Just before daylight we were carried through into the main temple building where some reeds and a mat had been spread on the floor, upon which we were laid. A guard of five or six being left in charge, the remainder dispersed, understanding that our case was to be decided in the morning.

Thus for the fifth time we find ourselves delivered from death for, although we could not say how our case would go eventually, the Lord had stayed their hand and prevented our being killed on the spot when captured.

As we lay there, wet, muddy, bound and aching, we appreciated the time of quiet that followed which was spent in prayer and in encouraging each other in the Lord.

Shortly after sunrise, the people began to arrive, and for the next three or four days there was one constant stream of curious people crowding into the temple to look at us, and I assure you that the being "looked at" was not the easiest of the many things 
He has cnabled us to endure "for His sake." Soon some of the leaders appeared on the scene, and for over three hours I sat there, bound and propped against the leg of the incense table, to undergo a severe cross-examination. Of course, I told the truth, and at last I think they werc obliged to own themselves baffled, as one confessed that I had a mouth full of Huailuh dialect, another that he had seen a boat the previous morning answering the description given, while a third declared I could not be a Romanist Priest because I had two wives and children!

Our cords were now removed and-food was given to us, and we were told that they had decided to send two of their number to Paotingfu, to obtain of the officials there confirmation of what I had said. One fact alone I had withheld from them and that was the Governor's order to the Boxers to kill us. I simply told them that they had cleclared it was impossible to take us to Tientsin, as promised by the Governor, and had made us leave the boat.

Feeling sure they would learn the truth at Paotingfu, there seemed very little hope of our lives when the deputation returned. This was Thursday morning, August 6 th, and the men did not return till Saturday evening. All that we went through in the interval I cannot attempt to tell. During the day the crowds kept me incessantly in conversation, answering the same questions over and over again. Many hundreds of Boxers visited us from all the country round, carrying their ghastly weapons, and by their looks thirsting for our blood. The heat and the myriads of flies were additional trials, while at night, although we were not bound after the second night, the nosquitoes, vermin and rats were terrible, so that with the hard uncomfortable bed and our aching bodies sleep was out of the question, until the Saturday night, when we slept I suppose from sheer cxhaustion. We enabled the children to sleep by keeping up a constant fanning over them. Those told off to guard us each night scemed designedly to talk as if something were going to be done with us next day, keeping us in constant uncertainty. To the praise and glory of God I bear record that we all of us realised and enjoyed His sustaining grace and keeping power, but at the same time I must humbly confess that I sometimes grew impatient under the continual strain of being questioned and insulted by the crowd.

On the Saturday night I was fetched round to their meeting room to hear the result of the deputation's visit to Paotingfu, and found myself in a room full of respectable tradesmen and scholars. These were the civil members of the Company of Boxers whose military people had captured us.

I learned that the society had only been formed here in self defence, as only in this way could they be safe from the depredations of the numerous societies in the district; and that their city had no resident magistrate, but was governed by an adjacent larger city, with the help of the neighbouring tradesmen and gentry.

The Governor had been very angry when he heard we had been let go alive, and that these people did not kill us as soon as they 
found us, and he had now given to them the same order that he gave the others. The civil part of the society we were now held by being much stronger than the military, they had overruled any other wish there may have been, and determined to protect us and send us down to Tientsin when the way was clear. They had won over the rougher element by the promise that as long as we were there and they had to guard and protect us, the whole comyany, about forty, should be provided with food, and towards this expense all the tradesmen subscribed liberally. Truly it was "a wonder to many" that we had not been killed again and again, as we should have been had we fallen into the hands of any other society in that district. Only a quarter of a mile below where we left the boat, a native Roman Catholic had been killed the very day when we were hiding in the reeds, and we should certainly never have passed a place five miles further down the river. And here we were, a little helpless company, allowed to escape by those who had the highest authority for killing us, while a whole city of gentry and tradesmen were turned to be our protectors and friends!

Yes! Those who know not our God may well marvel at all $\mathrm{He}$ wrought on our behalf. No doubt their decision was largely influenced by their superstition; the fact that we had been spared by one band of Boxers made them afraid to injure us. One and all declared that it was, because I had accumulated so much merit that Heaven itself had intervened on our behalf and prevented man's will from being done upon us. Thus for the sixth time our lives were preserved, and we were guarded day and night by some at least who would have killed us if they had had their own way.

There was some doubt as to whether they would be able to hold their own against the number of Boxers who were expected on the following day, Sunday, to attend the funeral of the two who had been killed by the Romanists. I suppose between three and four thousand thronged the town, but although there was some discussion, and a lot of threatening to make off with us and kill us, they were restrained. From the night of our capture little John drooped; persistent diarrhœa set in, he lost all his flesh and in a few days had scarcely strength to stand alone, while his terror when the people got at all noisy, or he saw their weapons, was most distressing. On the Monday my dear wife sickened with dysentery and was soon utterly prostrate. For two days we even despaired of her life. We had no means of giving her relief, and as to dieting it was out of the question. Vera had bad diarrhoea most of the time, but retained her appetite and her brightness throughout, and was a great favourite with all the people. I suffered every night with neuralgia, while all, especially Miss Greggand myself, really knew what it was to suffer from hunger. Only two meals a day were provided for ourselves and our keepers, and they were of the coarsest kind and generally undercooked. Not being accustomed to it, we could not like the natives eat sufficient at the 7 o'clock morning meal to last till the afternoon meal at between 4 and 5 o'clock. This matter of food therefore became one of our special 
requests day by day as we laid our needs before the Lord, praying that some heart might be touched to give the children something extra in the way of a dough cake, fruit, etc. Very few days passed without our receiving many little kindnesses in this way from the people who thronged to see us, and each evening we could praise for answered prayer. By the third night we had recovered our bedding. I told the men where we left it and they found it and dried it for us. Most grateful we were for something softer to lie on. The little Bible and the cash had been taken on the night of our seizure; the latter we never saw again, but the precious Book was restored to us on the sixth day, by request, looking as though it had been well handled. It was a new experience being without money. Occasional odd cash were given to the children, and these were jealously stored up until there were enough to buy a cake, or some sugar candy, as a special treat. One man out of the goodness of his heart gave me 30 cash saying, "I am sure you must be pining for a smoke; this will buy you a little tobacco." With this little fortune we were able for several days to buy my wife a basin of millet soup, as she could not take the other food during her illness.

About a week after our arrival we were able to have a wash, and a day or two later I was allowed to have a shave. Miss Gregg, having gained permission to go down to the river with an armed escort, contrived from time to time to wash out some of our garments, but of course having no change we were obliged to be minus that garment until it was dry again. The vermin were a constant source of trouble to us, in fact it was impossible to keep ourselves free from them.

The daily and nightly discomforts, mentioned above, continued throughout our stay, with the addition of cold in the night during the last week or so. One day, carly in the afternoon, when there were few people about, I was standing over the ladies and children as they slept, keeping away the flies with a fan, and looking rather gloomily, I am afraid, out through the open trellis work of the door. Our guard were all having a nap, and one solitary sightseer was peering through at the foreigners. Presently a little crumpled tuft of paper was dropped through on to the floor. I saw him throw it, but thinking it more an act of contempt than anything else I took no notice of it. The man had moved off to the outer door, then stopped, and seeing that I had not picked it up he came back, motioning to the floor where it lay, and again walked off. My curiosity was now aroused and I took it up, opened it, and found within, in a good bold hand, these words-"Don't be afraid, for Chinese robbers nearly all have been killed by both Chinese and foreign soldiers. Peking and Tientsin belong to Europeans. Now I will go to Tientsin and tell your armies to protect you. You may tear it into pieces when you have seen." Looking up, I motioned my thanks, and my unknown friend left hurriedly. The idiom was certainly that of an English speaking Chinaman. I was so excited that I woke the laclies to show them. Miss Gregg at once claimed it as the "little bird" and letter she had looked for that day 
in the reeds. We were all elated and for a time our hardships all seemed much easier to bear for this little gleam of hope which the Lord had sent us. If this friend really went to Tientsin and made known our position to the British Consul, we felt sure something would be done for us, nor were we wrong, as the sequel will show. We listened daily for new's of the situation but could gather nothing definite from the conflicting reports that reached us, and now nearly three weeks had gone by since our capture, and still there seemed no better prospect of our getting down to the coast.

Could it be possible that it was barely a month since we left Huailuh? Many, many months seemed to have been crowded into that time. Our daily prayer became that the Lord would speedily open the door and set His prisoners free, and the prayer was answered, but in altogether a different way from what we had looked for.

On Monday, 3rd September, a large company of Boxers visited the place, and we noticed that their attitude towards us was more unfriendly than usual. One thrust the muzzle of his gun into my wife's face, and said something to the effect that they were "going to begin business to-day." The place was packed with them for more than two hours, insomuch that they were almost treading upon us. The children were especially frightened, and I was kept in constant conversation the whole time. If any of our own guard were about they usually politely asked them to move on when they had looked at us. We were greatly relieved when all had left again, but the following morning early we were conscious that something unusual was abroad.

We had just been reading together Psalm 146, and had laid hold of the 7 th verse, "The Lord looseth the prisoners."

We learned that the mandarin from the neighbouring town had come, but we could not gather if his visit was on our account. Soon after our morning meal, one of the head men came to tell us that they were in great trouble: the large party of Boxers mentioned had threatened to come in a body to-day and carry us off. The whole town and neighbourhood were in an uproar about us, and some of the leading gentry were endeavouring to "talk over" the men who had come to make the threat.

It was proposed to hide us in a small room away at the back of the temple, in the yard we were first brought into, and they would give it out that we had been sent off to Tientsin down the river. If the worst came, we and those resiclent in the suburbs would move into the city, close the gates, and resist any attack which the country Boxers might make in force.

It did not take long to gather up all we possessed and move to the room at the back, a small, damp and fusty place which it would be certain death to live in day and night for any length of time. My dear wife, who had been improving slowly for a few days, went back very perceptibly the first day, and John was now so poorly that he must be nursed continually. Certainly we were free from visitors! But being left so severely alone, and not knowing how matters were going, only added to the depressing influences of those two days. The second 
day we could hear a great deal of shouting and much excitement going on in the street, and at night, when all was quiet, we learned what a difficult matter it had been to keep off the attacking party of Boxers. The Civil department held a monster meeting in the city, which was attended by some five hundred tradesmen and gentry, and by good words, apologies, and promises, they had succeeded in preventing an attack on us. So busy had they all been that not a soul had been near us since early morning, and they forgot to bring us our afternoon meal till very late. When the Secretary with one or two others came at last, we had just passed nearer the point of despair than we had reached all through our trials. Sick, ill, tired, cold, hungry and uncertain, the black pall of despair was settling down on my soul. As evening came on, with tears I implored my wife and Miss Gregg to pray for me, when suddenly there was quiet and music in my heart. I listened to catch the tune, then my lips tremblingly took up the strain and sang,

\footnotetext{
"Praise the Saviour, ye who know Him.

Who can tell how much we owe Him ?

Gladly let us render to $\mathrm{Him}$

All we bave and are."
}

The ladies soon joined, and, as the warm comfort of the Lord's own peace flowed again in our hearts, we did not try to keep back the tears that would come.

There was quite a consternation when they suddenly remembered that amidst all their troubles they had forgotten us. Very soon three or four different kinds of cakes and food were brought along, and while we ate we learned something of what had happened. Later, I was invited across to the meeting-room and was told that we were to leave that evening by boat for Paotingfu !

With many assurances they tried to set our hearts at rest, but to us it seemed like going to certain death again, until one gentleman, taking advantage of a moment we had alone, told me that the English Consul, having heard that we were prisoners at Sinan, had sent to Paotingfu, demanding protection and safe escort to Tientsin, and that a Special Commissioner had been sent from Paotingfu to fetch us. He had come with the Mandarin the previous day, but they being just in the midst of their trouble had refused to hand us over, having told the Boxers that we had left the previous day; but they promised to escort us to Ancheo, the neighbouring governing city, and hand us over to the Commissioner there.

At once we felt sure that our "little bird" had fulfilled his promise and had made known our dangerous and destitute condition to the authorities at Tientsin. It was our God who had enabled the Sinan people to restrain that horde of Boxers and just in the nick of time opened the way for our removal from the place.

This I record, with deep wonder, love and praise, as the seventh deliverance from death that $\mathrm{He}$ has wrought on our behalf, and these seven escapes have all been from definite and seen dangers; what of 
the many unseen designs and schemes of the Evil One which God had overthrown and from which $\mathrm{He}$ had delivered us?

One such has just come to our knowledge: during the brief stay that we had at Paotingfu the first time, armed Boxers had hung around the women's prison all the time, and one in particular had declared his intention to have a look at the "foreign devils," and a cut at them too, if he had the chance. The official, however, not wishing such a thing to happen within the precincts of his Yamen, had told off a strong guard to keep an eye on the building and prevent trouble.

So the door of our prison was opened and prayer answered, but not to go east to 'Tientsin, as we hoped, but to return to Paoting-fu, as His perfect will saw good.

We knew that owing to the Boxer movement being so strong and wide-spread, the way to Tientsin was practically impassable for a foreigner, and so had the Lord led us to trust Him that we went forward, knowing all would be well. "When He putteth forth His own sheep, He goeth before them."

About midnight on Wednesday, 5th September, we walked down to the riverside where two boats were waiting. Ourselves and six or seven of the escort embarked on one, some of the gentry and the rest of the escort on the other. I almost carried my dear wife who was too weak to walk.

Food had been made for us before starting, and now we were sent off with many expressions of good will from the little throng of tradesmen, etc., who had come down with us.

It was only six miles up stream to Ancheo, which we expected to reach easily by daybreak, but a heavy thunderstorm came on when about a mile out, and after anchoring till the rain ceased they elected to return to Sinan, get some refreshments and start again at daylight. Consequently we arrived on 6th September, about 8 a.m., having met two boats with soldiers who had been sent to look for us, as we had not turned up as early as had been promised.

Though short, it had been a most uncomfortable journey. There were no cabin divisions in the boat and, owing to the rain, the six men and ourselves were a!l crowded under the matting cover. Great numbers gathered on the banks to get a look at us, our fame having gone before. We were transferred to another big open boat, even less comfortable than the other, having only the matting covering without any screens.

Presently the Commissioner and local mandarin came on board and had a short conversation with us; then the word was given and a start made, we following close in the wake of the Commissioner's boat, which, by the way, was one of the most comfortable of the house-boat description.

I forgot, until the local official had left the boat, to ask for some money for travelling expenses, which it was his duty to provide, so we now found ourselves without money, without food, and a day's journey before us. The four soldiers and three Yamên men, who formed our new escort, together with the boatmen, all kindly shared 
their food with us and gave us a drink of tea. At the half-way place the escort told the Commissioner our position, and he immediately sent to buy us ten small dough cakes. In passing villages where there were Boxers, we all lay down, and they screened us as much as possible by hanging up garments at each end of the covering. How we enjoyed the fresh air, sunshine, and beautiful outlook on the fast ripening crops. Dear little John, who had scarcely smiled during the past three weeks, now pointed to this and that object which interested him. New life was put into us all, but I am afraid the trying experiences of the night more than counterbalanced the help we had gained during the day. When only about three-quarters of a mile from Paoting-fu and just before sunset, another storm came on, compelling us to anchor and, as the city gate would be closed, to spend the night there.

Again all sought the shelter of the matting cover, and the seven men and ourselves were all huddled up together through a very miserable night. It was impossible for all to find comfortable lyingdown room, and with our few thin garments it was exceedingly difficult to keep warm: WVe managed to cover my wife and the two children with the bedding, while we two stronger ones roughed it; but, as they all three suffered with constant diarrhoea, none of us got much rest. Soon after dawn, however, we moved on towards the city, and by sunrise were anchored close by the South gate. The Commissioner now came on board again and gave us 500 cash and more cakes. He asked how the Consul at Tientsin knew we were at Sinan, and a few other questions, then, promising we should not be separated, told the escort to take us down to the district Yamên. Little John clapped his hands with delight at the sight of the cash, exclaiming, "Oh, look what a lot of money we've got! Praise the Lord!'

We quite expected a cart would be provided. As it was nearly a mile away, I explained to the soldiers that I was afraid my wife could not walk so far, and they told me to carry her on my back, and they would help with the children and our few belongings! Although she was now exeeedingly light, I was correspondingly weak, so she attempted the walk, and with Miss Gregg's help, and by going very slowly, was enabled to get there; the Lord giving the strength. What a changed aspect the city now wore! One could hardly recognise it as the same place. Soldiers were in evidence everywhere; many of the shops were closed; the streets, usually so thronged, seemed forsaken.

IVe were told by our escort on the way up that there had been a panic when it was rumoured that foreign troops were coming to the city. Many of the tradesmen and people had fled, a lot of the disbanded soldiers had run wild and pillaged right and left, but the officials had nipped this in the bud and executed a few dozens of them. And that peace was now restored and there were no Boxers left in the city. 'The last statement we afterwards found was very far from true.

After arriving at the Yamên, there was about an hour's delay 
while our papers were examined and the officials decided what should be done with us.

At last the underlings came and would have taken me off to the men's prison again alone, but, refusing to budge, I said that they could take me to the Mandarin and I would explain to him. At this they went away, returning shortly to say that we were all to go to the women's lock-up. What a palace it seemed after our quarters of the past three weeks. How thankfully we settled down and for the time being desired nothing better! Very soon we were visited by one and another of the Yamên people who were profuse in their congratulations upon our escape, etc., etc. Nor was it long before a marked change in their treatment of us was apparent.

WVe rose now in the scale rapidly, extra bedding was brought for us (the cheapest available), and I was allowed to have a shave, the Mandarin's own barber being sent for the purpose. New paper was put in the window to keep out the cold at night, while again and again the women in charge were enjoined to look well after us and take care that we lacked nothing.

The next day, Saturday, September 8th, was the 15 th of the Chinese Sth Moon, a great feast day. The Mandarin sent us a meal from his own kitchen, with a present of moon-cakes and foreign sweets for the children. We were told that we should have rooms in the Mandarin's private quarters, but that, as there was no room there to spare, a suite of rooms was being prepared for us in another Yamên and would be ready on the morrow. An official was appointed by the Provincial Judge, acting as Governor, to give us daily attention and provide us with everything we needed. He visited us on Saturday to learn what we wanted, then came on Sunday with a new rig-out for each of us. What a relief to lay aside our dirty things and put on some clean, sweet, although cheap, clothing once more!

On Sunday our meals were sent again from the Mandarin's kitchen, and about 8 p.m. two carts, with four soldiers and others, came to take us to the new quarters. Thus by rapid strides, we were transformed from outcasts and prisoners into honoured guests! [Note -This change in treatment was no doubt occasioned by the receipt of a telegram from H.E. Li Hungchang, who was waited upon in Shanghai on September 7 th by the Hon. John Goodnow and Dr. John R. Hykes, Consul-General and Vice-Consul U.S.A., at the request of Rev. J. W. Stevenson, Deputy Director, China Inland Mission.]

On arriving at our new home we found two fairly large rooms, simply furnished, and moderately clean (for Chinese); a cook with orders to serve us up anything we might like to ask for, and the four soldiers to guard us day and night and attend to us just as we chose to use them.

Here too we found two more new coverlets, and an additional suit for each one of us of rather warmer clothing.

Mr. Cheng, the official appointed to look after us, visited us constantly to sec to our comfort and inquire after our needs. I must not 
forget to mention the courtyard and small garden where we could daily get fresh air and sunshine. Little John picked up perceptibly from the very first day here. My dear wife, too, although slowly and with repeated painful relapses, made progress to recovery, and in a fortnight was enabled to help and relieve Miss Gregg, who for five weeks had been a mother to my bairns. During the first ten days, all of us, notably Miss Gregg and myself, suffered acutely from painful and severe diarrhœa, while my old complaint of neuralgia continued to trouble me nightly. But as time went on good diet, clean surroundings, fresh air and rest, combined to put us all in a better state of health. We were able to buy "Condensed Milk" in the city, and this was an untold boon to all, especially the children. Many of the officials came to see me and gave me quite a number of presents, but whilst we praised God for every token of His care and especially for the lead pencils which came from the telegraph office and enabled us to begin our diary, we could not but be troubled by the fact that so short a time before these very people were consenting to the death of our loved ones. IVhat a solemn thing it was to be living in that city where so many of God's people had laid down their lives for Him, and as we heard from the three Christians who were permitted to visit us the details and horrors of those days do you wonder that our hearts turned sick within us?

About a week after our promotion, I was given permission to telegraph to Shanghai news of our safety, at the Provincial Judge's expense, although I was somewhat restricted in what I should say. In six days a reply came, "Halleluiah! Have wired news home. Wait instructions from Tientsin or Peking." This, our first communication from the outside world for four months, was pinned upon the wall, that we might continually refresh ourselves by reading it.

Towards the end of our third week here, I received a letter from the Consul at Tientsin, with a note added by Mr. Lowrie. This, too, filled our hearts with rejoicing as we learned all that was being done for our safety by the authorities in Tientsin, and also by our praying friends there.

About this time I was given facilities to write to our Shuentehfu friends, who are still at Chengtingfu, which place we learn had not been destroyed. Until they received this letter, they did not know if we were alive or dead. In fact they had given up all hope of seeing us again, as all the rumours were that we had been killed thirty miles down the river by Boxers.

A very real break comes into our diary at this point through my dear husband's serious illness. He was unable to write, and so I was led to continue our testimony to the Lord's goodness and mercy.

The long waiting time of between five and six weeks at Paotingfu was a very real testing time. The Chinese officials were always promising to send us to the coast, and just at the last moment some excuse was forthcoming, roads not safe, \&c. \&.c. 
They evidently had some definite purpose in keeping us. What was it? The most probable reason was to make use of us in the event of foreign troops coming into the district, and we were confronted by the fear that in the end they might make a final thrust at the enemy by killing us. One day, as Miss Gregg and I were talking about these things and feeling cast down, Vera, who was playing beside us and apparently taking no notice, looked up and said, so quickly and with such confidence, "Aunite, the Lord looseth the prisoners" (our Sinan text), then she again resumed her play. As we accepted her rebuke, our faith was strengthened and we could not but acknowledge that " out of the mouth of babes and sucklings the Lord has perfected praise."

How little we realised then the path which the Lord had for us to tread! For weeks our little darling had been suffering from dysenteric diarrhœea, sometimes better sometimes worse, and yet through it all so full of life that it helped to quiet our fears in regard to her, and we kept hoping that the change to the coast would completely restore her. We were as careful as circumstances permitted in reference to her diet, and it was good to see how she helped us by her self-denial. Whilst we were still praising God for my gracious recovery, we were brought face to face with the fact that in her case the diarrhoea was giving place to dysentery. All thought and attention were now centred in our darling. Again and again we thanked God for the condensed milk which $\mathrm{He}$ had kept in that City for us, and which we husbanded for her.

We saw His tender loving care in strengthening me that I might have the privilege of nursing. How can I describe those days! Sorrow too deep for words filled our hearts as we watched our darling suffer and were powerless to help her, though the Lord gave many seasons of semi-consciousness, in answer to prayer. Could it be that when deliverance was so near, the Lord wanted to take her to Himself?

$\mathrm{He}$ alone could and did still our hearts, and cause us to triumph over all the darts of the Evil One when tempted to doubt the Lord's love. The dysentery passed away and we were filled with hope. On October 8th she seemed much better, even asking me to make her some toys, though the desire for them passed away almost as soon as expressed. In the afternoon she began to complain of pain again, and that night she grew rapidly worse, though the dysentery did not return.

The next day we were shocked to see the change in our darling, but we did not realise that the end was so near. On the evening of 9 th, as I had been up most part of the previous night, my husband kept the first watch. About 3 a.m. I rose to take my turn, and as I looked at my darling I saw that a change had come over her. She was dying. I asked my husband if I should call Miss Gregg. I did so, and we three knelt beside her. She did not regain consciousness again, although she asked her father to lift her up and give her medicine, and about 4 p.m. October Ioth, after nearly a fortnight's illness, she fell asleep. In the solemn hush of that hour, God drew very near, and bound up our broken hearts, as with faltering lips we said, 
"He is worthy." WVe did not sorrow as those who have no hope, for we know that those who sleep in Jesus God will bring with Him, and that it is only "Till He come." His purposes through her had been fulfilled. She was undoubtedly used of God to preserve our lives. Her bright loving ways touched the hearts of the people and led them to spare us. Yes, her work was done, and in a very real sense her life was laid down for Jesus' sake and for China.

The next day the Chinese officials brought us a coffin, and our darling's body was taken to a temple near by, and remained there until further arrangements could be made.

This seemed to be the final strain for my dear husband. He had caught cold a night or two before, when watching our darling, and now there was an utter collapse.

He complained of much pain; to swallow solid food was an utter impossibility; any attempt at it made him quite faint, and what food he took passed through at once, undigested. Each day found him decidedly weaker, and again we resorted to prayer. We heard rumours of French troops appoaching, which filled us with hope and thankfulness, but we could not understand why the officials left us so severely alone during these few days.

After many false alarms, the first detachment reached Paotingfu on October I $3^{\text {th. }}$ This we heard from the soldiers who kept guard; no one else came near. How was it? On Sunday morning there was a sensation and a rush. The Provincial Magistrate was announced. Now, we thought, all is well. But he simply told us that the French were there on railway business, and would have nothing to do with us! Monday passed quietly away, my husband still getting worse. On Tuesday, Oct I6th, we decided to write to the French Colonel and ask the favour of medical help. Just as a soldier was on the point of starting, our eyes were gladdened by the appearance of a Captain $\mathrm{D}$ - in the doorway. The Colonel had just heard from a French and English spcaling Chinaman, whom the Captain brought with him, that we wcre in the city, and at once sent us an invitation to go into the French camp, an invitation which we were not slow to accept. About 4 p.m. an ambulance was brought for Mr. Green, and under a stong escort of French soldiers we left the city. We received much kindness from the French Colonel and all the officers during our stay there, the only disadvantare being our inability to speak French. Our conversations had to be carricd on through the young Chinaman mentioned above, and this made a real difficulty in reference to Mr. Green.

We learned from the French that when the officials were questioned as to why they had not mentioned the fact of our being in the city, they replied that they rather wanted to send us to the coast but that we did not wish to go!

The British troops from Peking were now drawing near, and almost as soon as they arrived, October 19th, General Gaselee and several officers came to see us. The General was most kind to us 
and offered to send the doctor round at once to see what could be done for my dear husband.

Imagine what the sight of English faces and the sound of English voices meant after all these months! They reminded us that we were now in the midst of friends. Yes, the time of our deliverance had come, and with grateful adoration, too deep for words, we praised God.

On Saturday, October 2oth, we were handed over to General Gaselee and taken to the Field Hospital, where Mr. Green had the best medical help, so valuable in his critical condition. My husband was found to be suffering from hill diarrhœa and a complete nervous break down. General Gaselee gave instructions that no expense was to be spared. Major Thompson was most kind and attentive, as were many others.

On Sunday, October 2 Ist, we had the intense joy of welcoming Mr. and Mrs. Griffith and their baby, also Mr. Brown, who had just arrived from Chengtingfu, where they had been for twelve weeks. What a glad reunion it was!

On Monday, arrangements were made for us to leave for Tientsin on the following day, by boat. We were quite a large party. Mr. and Mrs. Griffith and baby, Mr. Brown, two sick officers, a war correspondent, and several others besides ourselves. We brought dear Vera's coffin with us. Lieut. Bingham and Dr. Major Thompson were in charge, and there was a strong escort. Mr. Green got on very nicely until Friday afternoon, when his head began to trouble him. That night he was almost unmanageable, and he had not regained consciousness when we reached Tientsin on Saturday, October 27 th.

The doctor at the Gordon Hall, where we were first taken, told us that he was dangerously ill, and after further consultation it was decided that it was best to have him removed to our China Inland Mission Home. Here the difficulty of getting a trained nurse had to be faced, but again the Lord provided in His own wonderful way. Dr. Stevenson, a lady of the American Methodist Mission, offered her services, which were most gratefully accepted.

Sunday was a day of much prayer and anxiety for my loved one, but, praise God! on Monday morning he regained consciousness. He is still very very ill, but our hope is in God, and "He is able."

Looking into the future, we realise that, as it has been, so it must be step by step with God. We are as those who are "alive from the dead." How solemn! How heart searching! We cannot understand why we have been spared when so many of God's dear children have been called to lay down their lives for Him. We can only say, "It is the Lord." A more helpless little band there could not have been, so that the glory is all His own. We have often turned to Acts XII, where we read that "Herod the King put forth his hands to afflict certain of the Church, and he killed James the brother of John with the sword; and when he saw that it pleased the Jews he proceeded to seize Peter also, ; . intending after Easter to bring him forth to the people," But God had another 
purpose for Peter, and so we read, "Now I know of a truth that the Lord has sent forth His angel and delivered me out of the hand of Herod, and from all the expectation of the people of the Jews."

"His ways are not our ways, but as the heavens are higher than the earth so are his ways higher than our ways," and our hearts are still.

May "the God of all comfort" comfort the many sorrowing hearts of those who have lost dear ones, and cause them to see "the bright light in the clouds." He was and is glorified in our lives.

Thursday, November Ist.-Our little darling was laid to rest in the English Cemetery here. How different it might have been, and has been with others! Many of God's dear children gathered with us to commit her body to the ground. "Until the day dawn and the shadows flee away." 




\section{PLEASE DO NOT REMOVE CARDS OR SLIPS FROM THIS POCKET}

\section{UNIVERSITY OF TORONTO LIBRARY}


